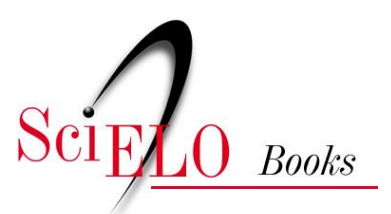

\title{
Judiciário e economia no Brasil
}

\author{
Armando Castelar (org.)
}

CASTELAR, A., org. Judiciário e economia no Brasil [online]. Rio de Janeiro: Centro Edelstein de Pesquisas Sociais, 2009. 140 p. ISBN: 978-85-7982-019-9. Available from SciELO Books <http://books.scielo.org>.

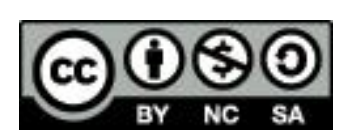

All the contents of this chapter, except where otherwise noted, is licensed under a Creative Commons Attribution-Non Commercial-ShareAlike 3.0 Unported.

Todo o conteúdo deste capítulo, exceto quando houver ressalva, é publicado sob a licença Creative Commons Atribuição Uso Não Comercial - Partilha nos Mesmos Termos 3.0 Não adaptada.

Todo el contenido de este capítulo, excepto donde se indique lo contrario, está bajo licencia de la licencia Creative Commons Reconocimento-NoComercial-CompartirIgual 3.0 Unported. 


\section{BIBLIOTECA VIRTUAL DE CIÊNCIAS HUMANAS}

\section{JUDICIÁRIO E ECONOMIA}

NO BRASIL

\section{Armando Castelar (organizador)}




\section{Armando Castelar \\ Organizador}

\section{Judiciário e Economia no Brasil}

Esta publicação é parte da Biblioteca Virtual de Ciências Humanas do Centro Edelstein de Pesquisas Sociais - www.bvce.org

Copyright (c) 2009 Armando Castelar (organizador)

Copyright (c) 2009 desta edição on-line: Centro Edelstein de Pesquisas Sociais

Ano da última edição: 2000, Sumaré

Nenhuma parte desta publicação pode ser reproduzida ou transmitida por qualquer meio de comunicação para uso comercial sem a permissão escrita dos proprietários dos direitos autorais. A publicação ou partes dela podem ser reproduzidas para propósito não comercial na medida em que a origem da publicação, assim como seus autores, seja reconhecida.

ISBN: 978-85-7982-019-9

Rio de Janeiro

2009

centro edelstein de pesquisas sociais

www.centroedelstein.org.br
Centro Edelstein de Pesquisas Sociais

www.centroedelstein.org.br

Rua Visconde de Pirajá, 330/1205

Ipanema - Rio de Janeiro - RJ

CEP: 22410-000. Brasil

Contato: bvce@centroedelstein.org.br 


\section{SUMÁRIO}

INTRODUÇÃ̃O

Armando Castelar Pinheiro

IMPACTO SOBRE O CRESCIMENTO: UMA ANÁLISE CONCEITUAL .1

Armando Castelar Pinheiro

1.1. Introdução ......................................................................................

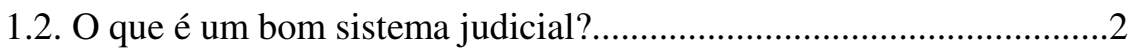

1.3. Como os sistemas judiciais afetam o crescimento econômico? ........15

1.3.1. Uma perspectiva tecnológica ............................................................ 15

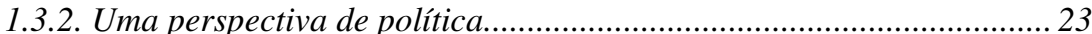

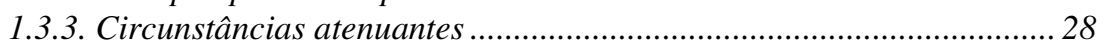

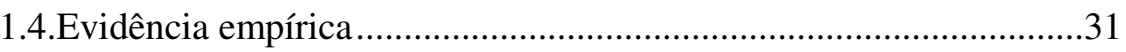

O JUDICIÁRIO BRASILEIRO: A AVALIAÇÃO DAS EMPRESAS. .41

Bolívar Lamounier,

Maria Tereza Sadek,

Armando Castelar Pinheiro

\section{O JUDICIÁRIO E A ECONOMIA: EVIDÊNCIA EMPÍRICA PARA O CASO}

BRASILEIRO

Armando Castelar Pinheiro

3.1. Introdução . .54

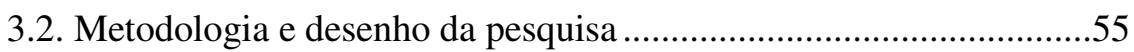

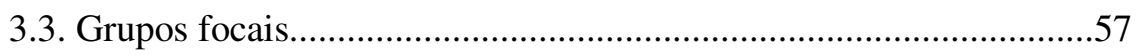

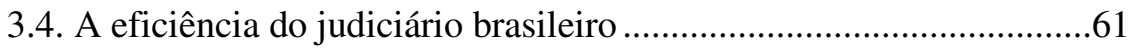

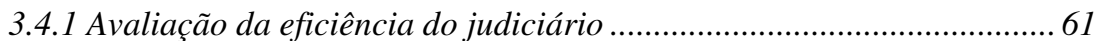

3.4.2 Contextualizando a ineficiência do judiciário ........................................62 62

3.4.3. Avaliando em que extensão o mau funcionamento da justiça afeta a

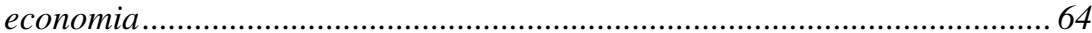

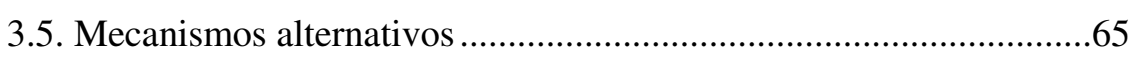

3.6. Impacto do mau funcionamento do judiciário....................................67

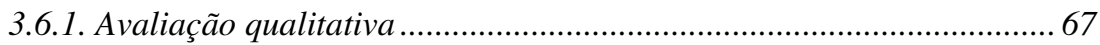

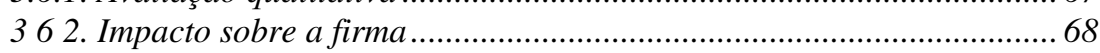

3.7. Reação à melhoria de desempenho do judiciário

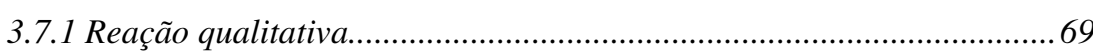

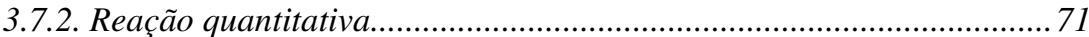

O PONTO DE VISTA DOS EXPORTADORES ....................................................... 76

Vladimir Brandão

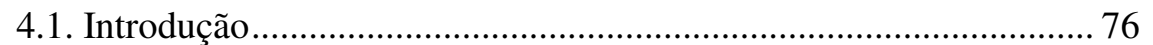

4.2. Metodologia e síntese dos principais resultados.............................. 79

4.3. Uma avaliação comparada do judiciário brasileiro ............................ 89

O JUDICIÁRIO E AS MICRO E PEQUENAS EMPRESAS ..................................93

Eunice Nunes

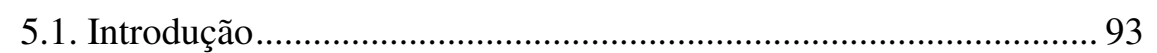

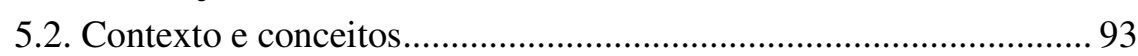

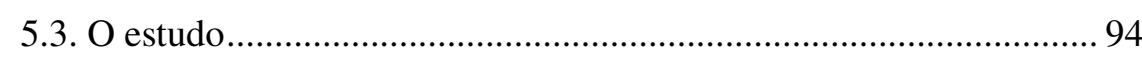

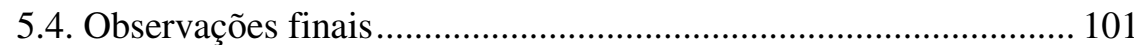

\section{O IMPACTO DO JUDICIÁRIO NAS ATIVIDADES DAS INSTITUIÇÕES}

FINANCEIRAS

Marcio Aith

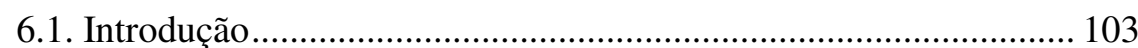

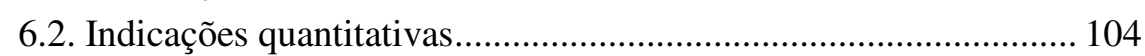

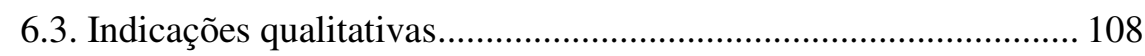

CONCLUSÕES

Armando Castelar Pinheiro

REFERÊNCIAS BIBLIOGRÁFICAS.

125

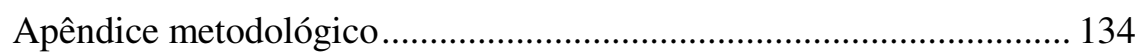

A.1. Derivando a utilidade de se recorrer à justiça ...................................... 134

A.2. Um modelo simples para ilustrar o impacto do mau-funcionamento do

judiciário sobre os investimentos .................................................................. 136

A.3. Um modelo de ilustração do impacto do mau funcionamento do

judiciário sobre os preços .......................................................... 138

A.4. Um modelo para ilustrar a importância de mecanismo de proteção.... 140 
Para o sucesso da pesquisa apresentada neste livro foi fundamental a participação de um grande número de pessoas e instituições. A falta de espaço nos impede de nomeá-las e agradecê-las individualmente, razão pela qual o fazemos aqui de forma coletiva. Queremos, no entanto, registrar nossa especial gratidão aos pesquisadores e colaboradores do Idesp, que nos ajudaram na execução de todo o estudo; aos empresários e executivos das firmas entrevistadas para a elaboração da pesquisa, que nos brindaram com seu tempo e atenção; e à Fundação Tinker e ao Banco Interamericano de Desenvolvimento, pelo apoio e o estímulo sem os quais este trabalho não teria sido possível.
Em 1996, os torcedores do Botafogo finalmente puderam celebrar a conquista do campeonato estadual de 1907. Só então a justiça decidiu em favor da agremiação alvinegra a disputa que sustentava contra o Fluminense, que também reclamava o direito àquele título. Obviamente, depois de 89 anos, poucos, ou talvez nenhum, daqueles que iniciaram a contenda se achavam vivos para comemorar a decisão. Mas, infelizmente, a frustração dos torcedores de futebol não é o único custo que a ineficiência judiciária impõe à sociedade brasileira. $\mathrm{O}$ mau funcionamento da justiça tem efeitos importantes sobre a atividade econômica, por exemplo. É o que nos propomos demonstrar neste livro.

A insatisfação com o funcionamento da justiça é um fato amplamente demonstrado por pesquisas. Em numerosos países, pesquisas de opinião têm evidenciado o grande descontentamento que hoje existe em relação ao desempenho da justiça. Por toda parte, integrantes do próprio judiciário têm apresentado críticas e proposto reformas; no Leste Europeu e na América Latina, várias mudanças foram efetivamente introduzidas de alguns anos para cá.

No Brasil, as deficiências do judiciário, decorrentes de seu perfil institucional e de sua estrutura administrativa, se veem acentuadas pela: instabilidade do quadro legal do país, pelo arcaísmo e excessivo formalismo dos códigos de processo, pela má formação de juízes e funcionários, entre outros fatores. De maneira geral, os procedimentos vigentes tornam o processo judicial muito lento e burocratizado; muitos estudiosos chegam mesmo a afirmar que esse conjunto de fatores negativos deve ser visto como uma "cultura" jurídica, sublinhando, com esse termo, a complexidade e a inércia temporal do fenômeno a que se referem. A aceitação dessa "cultura" pelos operadores do direito, o excessivo recurso a argumentos processuais como forma de protelar decisões sobre o mérito das questões, enfim toda essa pesada morosidade contribui para o descrédito que uma parcela expressiva da sociedade devota ao judiciário como instância para a resolução de seus conflitos. Uma pesquisa do IBGE, publicada em 1990, mostrou que dois em cada três brasileiros envolvidos em conflitos 
preferiam não recorrer à justiça. Em 1993, uma pesquisa do IBOPE revelou que $87 \%$ dos entrevistados acham que "o problema do Brasil não está nas leis, mas na justiça que é lenta", e que $80 \%$ das pessoas pensam que "a justiça brasileira não trata os pobres e os ricos do mesmo modo".

O que há de novo na discussão sobre o mau funcionamento do judiciário é a percepção de que ele pode ter impactos significativos sobre o desempenho da economia. Esse reconhecimento se insere em um movimento mais amplo, que tem se caracterizado por um crescente interesse no papel desempenhado pelas instituições na promoção do desenvolvimento econômico (North, 1981; Olson, 1996). De acordo com a assim chamada "economia institucional", as instituições estão entre os principais determinantes do crescimento econômico. Com efeito, segundo Scully (1988), países com boas instituições são duas vezes mais eficientes e crescem três vezes mais, em termos per capita, do que países pobres em "capital institucional".

Os sistemas jurídico e legal ocupam um papel de destaque entre as instituições que mais influenciam o desempenho econômico das nações, o que explica em parte o crescente interesse de advogados e economistas pelos temas cobertos pelo campo do direito e economia, ${ }^{2}$ como atesta o vertiginoso crescimento na quantidade de associações de "Law and Economics", bem como a existência de um numero também crescente de professores de economia lecionando em escolas de direito. ${ }^{3}$ Stigler (1992) aponta três áreas em que o direito e a economia interagem. Primeiro, os economistas têm tradicionalmente assessorado tribunais e advogados em casos antitruste e antidumping e em outros tipos de litígio no comércio internacional, bem como em casos decorrentes da implementação da política econômica de uma maneira geral. Segundo, a economia ajuda na compreensão tanto dos incentivos ao litígio, como do comportamento das partes durante o próprio

\footnotetext{
${ }^{1}$ Os resultados sobre as pesquisas do IBGE e do IBOPE foram extraídos de Faerman (1998). 2 Isso apesar da arguta observação de Stigler (1992, pp. 462-3) sobre a dificuldade de comunicação entre as duas profissões: "Enquanto a eficiência constitui-se no problema fundamental dos economistas, a justiça é o tema que norteia os professores de direito (...) é profunda a diferença entre uma disciplina que procura explicar a vida econômica (e, de fato, toda a ação racional) e outra que pretende alcançar a justiça como elemento regulador de todos os aspectos da conduta humana. Esta diferença significa, basicamente, que o economista e o advogado vivem em mundos diferentes e falam diferentes línguas".

${ }^{3}$ Ver, por exemplo, Van den Bergh (1996), Cooter e Rubinfeld (1989) e Stigler (1992)
}

processo de litígio e dos custos envolvidos. ${ }^{4}$ A terceira área, que mais nos interessa aqui, refere-se à análise do papel das instituições judiciais na determinação do ritmo e da forma do desenvolvimento econômico dos países. Quais são os pontos fracos e os pontos fortes dos diferentes sistemas judiciais e legais? Quais são os seus impactos distributivos? De que maneira esses sistemas deveriam ser reformados em países em desenvolvimento, com vistas a promover o crescimento econômico? Quais seriam, nesses países, os potenciais ganhadores e perdedores com a eventual implementação de sérias reformas nos sistemas de justiça? Estas são questões que a análise econômica pode ajudar a responder. De fato, a importância e a urgência de se responder a tais perguntas são hoje amplamente reconhecidas. Como assinala Haussman (1996, p. 41), "é cada vez mais amplo o consenso sobre o vínculo entre justiça e desenvolvimento econômico".5

Os problemas que afetam o judiciário na maior parte dos países em desenvolvimento, traduzindo-se em justiça morosa e por vezes parcial ou imprevisível, prejudicam o desempenho econômico desses países de diferentes maneiras. A proteção insuficiente dos contratos e dos direitos de propriedade estreita a abrangência da atividade econômica, desestimulando a especialização e dificultando a exploração de economias de escala, desencoraja investimentos e a utilização do capital disponível e, por fim, mas não menos importante, distorce o sistema de preços, ao introduzir fontes de risco adicionais nos negócios.

Os problemas decorrentes do mau funcionamento do judiciário tornam-se gritantes à medida que a economia é liberalizada e uma parcela maior da responsabilidade pela alocação de recursos na economia é transferida para o mercado. Vale dizer, na medida em que as economias em desenvolvimento adotam políticas voltadas para o mercado, por exemplo, liberalizando o comércio e recorrendo a privatizações, muitas das transações que antes se processavam no interior de grandes organizações estatais ou sob a coordenação do setor público são transferidas para o mercado. Essa mudança põe em relevo a importância do sistema judicial, do qual dependem, em última instância, a proteção e a garantia dos direitos e

\footnotetext{
${ }^{4}$ Este segmento de pesquisa se desenvolveu de maneira bastante satisfatória nos últimos anos, acompanhando o crescimento do número de processos, do custo dos julgamentos e do volume das compensações. Cooter e Rubenfield (1989) resenham a literatura referente a esse tema. ${ }^{5}$ Ver também The Economist (1996).
} 
contratos. ${ }^{6}$ É dentro desse contexto que instituições como o Banco Mundial e o BID preconizam uma nova onda de reformas, na qual a reforma do judiciário ocupa um papel de destaque (Rowat, Malik e Dakolias, 1995; Banco Mundial, 1997; Jarquín e Carrilo, 1997).

Neste contexto, é surpreendente constatar que o judiciário continua como uma baixa prioridade entre os estudos acadêmicos. $\mathrm{O}$ grau de insatisfação com o desempenho da justiça e a importância e urgência que hoje se atribui à sua reforma contrastam com o pouco conhecimento disponível sobre esse poder. Dos três ramos do governo, o judiciário é certamente o menos estudado. Essa constatação é válida para as ciências sociais das democracias avançadas, mas aplica-se a fortiori àquelas do Terceiro Mundo. Nestas, como é o caso do Brasil, a lacuna é mais séria. Com o término do regime militar (1964-85) e o retorno ao Estado de Direito, os estudos sobre o sistema legal em nosso país concentraram-se prioritariamente nas ameaças aos direitos humanos básicos e na desigual distribuição da justiça, com especial ênfase em questões de cor e gênero.

No campo da economia, a literatura sobre o papel dos sistemas judiciais na promoção do desenvolvimento é quase inexistente. Ou seja, entende-se que as instituições têm grande influência sobre a capacidade dos países se desenvolverem, e que o judiciário é uma das instituições mais importantes nesse processo, mas pouco se trabalhou a forma em que essa influência se dá, ou através de que canais ela opera. Ainda mais conspícuo é o escasso progresso feito até agora em avaliar a significação e medir a magnitude do impacto do mau funcionamento do sistema judicial sobre o desempenho da economia. Como assinalam Sherwood et al. (1994, p. 4):

Embora pareça autoevidente, a proposição segundo a qual processos judiciais sólidos melhoram o desempenho econômico acha-se longe de ter sido provada. A extensão desse estímulo não foi ainda estimada ou mesmo projetada.

Importa notar que esse desconhecimento sobre os custos econômicos decorrentes do mau funcionamento da justiça vem inibindo tanto um debate

\footnotetext{
${ }^{6}$ Como assinalam Summers e Thomas (1993, p. 249): "O estabelecimento de um bom sistema legal e judicial e de direitos de propriedade seguros é um componente essencial das reformas econômicas". Willig (1994, p. 156) observa: "A primeira lição é que, para se mostrar efetiva, a privatização de empresas estatais requer um conjunto adequado de instituições, um sistema legal efetivo, e uma estratégia desenhada para as circunstâncias específicas do país".
}

mais profundo sobre esse assunto como tentativas práticas de se melhorar a administração da justiça.

O estudo apresentado neste volume representa uma tentativa de mudar esse quadro, contribuindo para preencher, pelo menos em parte, essa lacuna de conhecimento. O trabalho foi concebido com um duplo objetivo: desenvolver uma metodologia para medir os custos econômicos do mau funcionamento do sistema judicial e aplicar essa metodologia ao caso brasileiro, obtendo estimativas numéricas desses custos.

A estrutura do livro, que se divide em seis capítulos, reflete a nossa abordagem ao problema. O primeiro capítulo analisa conceitualmente como a atuação do judiciário afeta o crescimento econômico, e resenha a literatura sobre esse tema. Nele é desenvolvido o instrumental teórico utilizado nos capítulos seguintes e são identificados e discutidos os canais através dos quais o judiciário influencia as decisões dos agentes econômicos. O segundo capítulo apresenta uma avaliação, por parte de empresários, sobre a qualidade do judiciário no Brasil, elaborada a partir das respostas a um questionário específico enviado a companhias em todo o país. Nesse capítulo, apresentamos também alguns resultados inéditos relativos à atividade litigante das empresas e ao processamento desses casos pelo judiciário. O terceiro capítulo discute os resultados de uma segunda pesquisa com empresas, também realizada em âmbito nacional, porém mais diretamente voltada à avaliação empírica do impacto do mau funcionamento da justiça sobre a atividade econômica.

Os capítulos 4 a 6 apresentam três estudos de caso a respeito do efeito da ineficiência do judiciário sobre empresas envolvidas no comércio exterior, micro e pequenas empresas e o setor financeiro.

Por terem um foco mais restrito do que as duas pesquisas com empresários e, ao mesmo tempo, descartarem a necessidade de analisar um grande número de companhias, esses estudos qualitativos permitem avançar no entendimento sobre a reação dos agentes econômicos ao mau funcionamento da justiça, focando em atividades que nos pareceram especialmente sensíveis à sua atuação. Por fim, apresentamos um sumário das principais conclusões desenvolvidas ao longo do livro, bem como algumas considerações sobre a relevância dos resultados de nossa pesquisa para o debate, ora em curso no país, a respeito da reforma do judiciário. 


\section{IMPACTO SOBRE O CRESCIMENTO: UMA ANÁLISE CONCEITUAL}

Armando Castelar Pinheiro

\subsection{INTRODUÇÃO}

$\mathrm{E}$ xiste hoje amplo reconhecimento de que a qualidade das políticas públicas e das instituições explica uma parcela importante das elevadas diferenças entre países no que diz respeito a níveis e taxas de crescimento do PIB per capita [North (1981, 1990), Barro e Lee (1994)]. De fato, na opinião de muitos analistas, essa não é apenas uma causa importante, mas a mais importante de todas as causas (North, 1981; Olson, 1996). Assim, para Olson (1996, p. 20), reformar a política econômica e as instituições é suficiente para rapidamente se alçar um país a uma trajetória de elevadas taxas de crescimento: "Qualquer país pobre que implemente políticas econômicas e instituições relativamente adequadas experimenta uma rápida retomada do crescimento".

Os argumentos de Olson encontram respaldo empírico em Scully (1988), que analisou o impacto das instituições sobre níveis de eficiência e taxas de crescimento em 155 economias de mercado. Scully chegou a três conclusões principais. Primeiro, que países dotados de boas instituições - ou seja, "sociedades politicamente abertas e comprometidas com a império do Direito [rule of law], a propriedade privada e a alocação de recursos pelo mercado" - crescem três vezes mais rápido, em termos per capita, do que países com instituições precárias $(2,73 \%$ contra $0,91 \%$ a.a.). Segundo, que países com instituições frágeis apresentam apenas metade da eficiência observada nos países dotados de uma boa estrutura institucional; e terceiro, que países com instituições precárias tendem a apresentar um declínio contínuo em eficiência, enquanto aqueles caracterizados por boas instituições já capturaram todos os ganhos de eficiência, de modo que, em tais países, "não se deve esperar uma melhora da eficiência ao longo do tempo".

${ }^{1}$ O trabalho de Scully (1988) pode ser criticado por diferentes motivos, quase todos discutidos na seção 1.4. Cabe aqui chamar a atenção para a forma um pouco ligeira em que e medida a qualidade das instituições de diferentes países. Não obstante, isso não invalida a conclusão de que países mais desenvolvidos tendem a apresentar instituições mais funcionais.
Olson (1996, p. 6) destaca dentre as instituições que considera mais importantes "os sistemas legais que garantem os contratos e protegem os direitos de propriedade". A importância de um sistema judicial que funcione adequadamente é assim assinalada por North (1992, p. 8):

De fato, a dificuldade em se criar um sistema judicial dotado de relativa imparcialidade, que garanta o cumprimento dos acordos, tem-se mostrado um impedimento crítico no caminho do desenvolvimento econômico. No mundo ocidental, a evolução dos tribunais, dos sistemas legais e de um sistema judicial relativamente imparcial tem desempenhado um papel preponderante no desenvolvimento de um complexo sistema de contratos capaz de se estender no tempo e no espaço, um requisito essencial para a especialização econômica.

Embora a importância de um judiciário eficiente para o crescimento econômico seja atualmente bem aceita, como demonstram as citações acima, a literatura sobre o tema ainda é escassa no que se refere à articulação conceitual da maneira pela qual os sistemas judiciais afetam o desenvolvimento econômico. Quais são, afinal, os vínculos entre justiça e desempenho econômico? De que maneira o comportamento dos agentes econômicos é afetado por problemas oriundos do sistema judicial? Neste capítulo, tentamos responder a essas questões, desenvolvendo a estrutura conceitual que será utilizada em nossa análise empírica.

\subsection{O QUE É UM BOM SISTEMA JUDICIAL?}

Sistemas legais em economias de mercado - ou como colocado por Cooter (1996), em Estados que seguem o princípio da "regra da lei" estabelecem as regras do jogo e os mecanismos aos quais os indivíduos podem recorrer para verem garantidos os seus direitos. Como assinalam Hay et al. (1996, p. 559), “o primado do Direito significa em parte que as pessoas usam o sistema legal para estruturarem suas atividades econômicas e resolverem suas contendas. Isso significa, entre outras coisas, que os indivíduos devem aprender o que dizem as regras legais, estruturar suas respectivas transações econômicas utilizando essas regras, procurar punir ou obter compensações daqueles que quebram as regras e voltar-se a instâncias públicas, como os tribunais e a polícia, para a aplicação dessas mesmas regras". 
Em particular, as leis relacionadas à atividade econômica desempenham quatro funções principais. ${ }^{2}$ Primeiro, definem e protegem os direitos de propriedade, direitos essencialmente privados. Segundo, estabelecem as regras para a negociação desses direitos, não só entre agentes privados, como também entre estes e o Estado. Terceiro, definem regras para se entrar e sair do mercado. Quarto, promovem a competição e regulam a conduta nos setores onde prevalecem monopólios. Adicionalmente, como observam Sherwood et al. (1994, p. 6):

Em sistemas de mercado, a estrutura legal (idealmente pelo menos) estabelecerá direitos de propriedade duradouros - os quais dificilmente serão alienados de forma arbitrária - e fornecerá os meios para que esses direitos permeiem e se façam valer ao longo de toda a estrutura de propriedade; permitirá um nível substancial de atividade; e garantirá liberdade suficiente para a associação no que diz respeito à formação de empresas e, considerando e definindo o caráter limitado da responsabilidade das partes, irá encorajar o crescimento do capital, estabelecendo as bases para a dissolução ordenada de associações, firmas, joint ventures, e assim por diante.

Independentemente da qualidade da legislação de um determinado país, essa legislação não se sustenta por si mesma. Para se mostrarem efetivas, as leis precisam estar lastreadas em instituições destinadas à sua aplicação e à resolução de disputas, instituições que precisam desempenhar essas funções de maneira eficiente. Nesse sentido, os tribunais desempenham um papel central nas economias de mercado, garantindo que o império do Direito de fato vigore. No entanto, embora a importância de bons judiciários em economias de mercado seja amplamente admitida, exatamente o quão importante são essas instituições é ainda uma questão em aberto. Para se avançar nessa direção, é essencial elaborar uma estrutura conceitual mais precisa a respeito dos vínculos entre desempenho judicial e atividade econômica. Para tanto, necessitamos de um critério para avaliar tal desempenho. Definições genéricas, como a que estabelece que "um bom judiciário é aquele que assegura que a justiça seja acessível e aplicada a todos, que direitos e deveres sejam respeitados, além de aplicados com um baixo custo para a sociedade" (e.g., Shihata, 1995, p. 14), embora capturem aspectos essenciais do problema, são de difícil utilização. Em particular, tais definições demandam julgamentos subjetivos complexos para se equacionar

\footnotetext{
${ }^{2}$ Banco Mundial (1996) e Gray et al. (1993) (in Shewood et al., 1994).
}

o fato de que alguns desses objetivos conflitam entre si (por exemplo, baixo custo, rapidez de decisões e amplo direito de defesa). A observação de Stigler sobre a dificuldade de conciliar justiça e eficiência traz um óbvio sinal de alerta (ver nota 2). Essa dificuldade também é apontada por Sherwood et al. (1994, p.9):

A obrigação efetiva do cumprimento da lei traduz-se inevitavelmente num trade-off entre justiça- no sentido da identificação da lei, da determinação dos fatos, de se chegar a uma decisão correta, estabelecendo-se a possibilidade de recurso e distribuindo-se os custos - e eficiência, em termos do tempo e dos custos privados e públicos envolvidos na condução de um litígio.

Nessa mesma linha, Cooter e Rubenfield (1989, p. 1068) alertam que, "enquanto a teoria comportamental, (que) trata as leis como preços, como incentivos para a ação, ... tem sido bem recebida... (e) a teoria normativa da eficiência é relativamente não controversa... como uma orientação ampla de política, ... a controvérsia permanece abundante quando a eficiência é vista como dominando outras normas de equidade e justiça". 3

Definir com precisão o que constitui um sistema judicial "ideal" mostra-se portanto uma tarefa não trivial, não só porque implica julgamentos subjetivos, mas também porque, como assinalado por Sherwood et al. (1994, p.7), "a linha divisória entre um sistema legal e seu respectivo sistema judicial não é autoevidente". Em particular, a capacidade dos tribunais de julgarem com presteza, justiça e previsibilidade depende de as leis terem sentido claro e serem bem escritas e consistentes com outras leis e com as práticas comerciais. Da mesma forma, para que os tribunais funcionem de forma eficiente, os contratos, quer se refiram a partes privadas, quer envolvam o Estado, devem estar corretamente elaborados, ser consistentes com a legislação e conter cláusulas passíveis tanto de verificação como de aplicação. É necessário, portanto, não só a existência de legisladores e juízes competentes, mas também de advogados e contadores bem preparados. Esta necessidade com certeza afigura-se como um problema especialmente crítico para as economias em transição. ${ }^{4}$ No restante deste capítulo, iremos com frequência nos referir aos sistemas legal e judicial como uma única instituição.

${ }^{3}$ Ver também Dixit (1996, pp. 13-15).

${ }^{4}$ A carência de pessoal especializado nesses países fica evidente no seguinte levantamento do Banco Mundial (1996, p.3): "a transição produziu um crescimento dramático no número 
Por conseguinte, embora não seja difícil achar uma definição do que é um bom sistema judicial, é provavelmente uma missão impossível selecionar uma única definição capaz de ser utilizada para fins de mensuração e que, ao mesmo tempo, satisfaça a todos os gostos e preferências. Sherwood et al. (1994, p.7) propõem, como alternativa, que se olhe para os serviços que produz o judiciário em termos de "garantia de acesso, previsibilidade e presteza dos resultados, além de remédios adequados". Hay et al. (1996, p.560) dão um passo além e sugerem que a qualidade do sistema judicial poderia ser medida pela frequência com que os indivíduos recorrem ao sistema e não a mecanismos concorrentes de resolução de conflitos e de aplicação da lei: "Para ser competitivo, o sistema legal deve sobretudo se mostrar mais atraente do que outros mecanismos, tipicamente privados, de resolução de conflitos e de imposição do estabelecido nos acordos". ${ }^{5}$ Um meio similar de avaliação, embora também indireto, é proposto por Williamson (1995, pp.181-2):

$\mathrm{O}$ resultado é que se pode inferir a qualidade do judiciário de forma indireta: uma economia com alto desempenho (expresso em termos de governança) irá permitir mais transações em uma faixa intermediária [i.e. contratos de longo prazo estabelecidos fora de organizações hierarquizadas] do que uma economia com um judiciário problemático. Em outros termos, numa economia com baixo desempenho a distribuição das transações tende se mostrar mais bi-modal - com transações em mercados a vista ou dentro de hierarquias e menos transações na faixa intermediária.

As implicações da sugestão de Williamson serão avaliadas nas duas próximas seções. Antes disso, podemos analisar como a qualidade dos "serviços" de um sistema judicial afeta as decisões dos agentes econômicos, focalizando a frequência de litígios. Vale aqui notar que um sistema judicial que funciona bem não é necessariamente aquele que se acha em uso constante. Ao contrário, seu papel é estimular as pessoas a transacionarem, conscientes que podem, caso necessário, recorrer aos tribunais para obrigar o

de advogados e nas oportunidades de treinamento a eles facultadas. Na China, por exemplo, o número de advogados licenciados cresceu de 3.000 em todo o período de 1957-80 para mais de $60.000 \mathrm{em} 1995$. Os inscritos em escolas de direito hoje superam a casa dos $30.000 \mathrm{e}$ o governo anunciou a meta de 150.000 advogados para o ano 2000".

O tamanho do setor informal é, neste sentido, um indicador do quão competitivo é o sistema legal e judicial de um país. Ao operar fora do sistema legal, o setor informal em grande medida abre mão do direito de ser protegido pela lei e pelos tribunais. cumprimento dos contratos e para proteger os seus direitos. Consequentemente, podemos afirmar que um bom judiciário não deve conduzir nem a muitos nem a poucos litígios.

Um judiciário que leve a muitos litígios não está sendo eficiente por duas razões. Uma, porque consome muitos recursos, tanto da parte dos litigantes (advogados, etc.) como do setor público (e.g. juízes e pessoal administrativo). Outra, porque litígios em excesso indicam que as leis e os direitos não se acham suficientemente bem definidos e/ou respeitados. Provavelmente também sinalizam que o sistema não está sendo eficiente em desencorajar casos que deveriam ser resolvidos no âmbito privado. Por outro lado, um número escasso de litígios é também sinal de que o judiciário não está funcionando bem. Mesmo que as leis e os contratos sejam escritos de forma transparente e consistente, na prática deve-se esperar a ocorrência de litígios, já que sempre haverá contingências que não estão previstas nas leis ou contratos (por exemplo, numa concessão de 50 anos) ou que não são contratáveis (acidentes de carro, etc.). Um pequeno número de litígios provavelmente indica que as firmas e os indivíduos não confiam que o judiciário vá proteger os seus direitos de maneira eficiente. Pode também indicar que os custos de se recorrer ao judiciário são muito altos, impedindo, na prática, o acesso universal à justiça pelas partes. ${ }^{6}$

Obviamente, o nível ótimo de litígios depende de muitos fatores, como a natureza do sistema legal (direito consuetudinário, muçulmano, civil etc.), a complexidade da economia (a produção de conhecimento, por exemplo, requer mais proteção legal do que a de produtos agrícolas), a natureza da propriedade do capital (no setor estatal, os litígios são resolvidos por comandos administrativos) e a disponibilidade, custo e qualidade de mecanismos alternativos.? No entanto, examinando como a "produção" do sistema judicial afeta a decisão dos agentes econômicos de recorrer ou não ao judiciário poderemos avançar na definição do que constitui um bom judiciário.

Para entender a decisão de se iniciar ou não um litígio, deve-se comparar o que se pode ganhar com o que se pode perder como consequência dessa decisão. Uma conclusão natural é que se recorre ao judiciário quando a utilidade esperada dessa ação é maior do que a de agir de outra forma. Da

${ }^{6} \mathrm{Na}$ Inglaterra, por exemplo, para disputas abaixo de $\$ 31.000$, os custos dos litígios geralmente superam o valor dos ganhos de compensação (Economist, 1996, p. 47)

${ }^{7}$ Ver, por exemplo, Gray (1991) 
mesma maneira, as partes em litígio buscam uma solução fora dos tribunais quando a utilidade de ambas é maior seguindo esta alternativa do que uma outra. No Apêndice Metodológico, esse raciocínio é utilizado para se derivar um modelo que permite identificar os principais determinantes da decisão de recorrer ou não ao judiciário. O modelo mostra que a utilidade advinda da utilização de um mecanismo específico de resolução de conflitos, como o judiciário, depende dos custos envolvidos, da rapidez com que uma decisão é alcançada, da imparcialidade do árbitro, da taxa de juros (ou, mais precisamente, da taxa de desconto intertemporal), e da previsibilidade das decisões e do tempo até que elas sejam alcançadas. $\mathrm{O}$ modelo mostra que um sistema que funciona bem deve ostentar as seguintes propriedades: baixo custo de acesso e decisões justas, rápidas e previsíveis, em termos de conteúdo e de prazo. Segue-se um resumo dos principais resultados obtidos no Apêndice, que deve ser consultado por aqueles interessados na sua derivação.

$\mathrm{O}$ custo ex-ante de se utilizar um método de resolução de conflitos depende do valor das taxas de acesso, de quanto se tem de gastar durante o processo de litígio, da probabilidade de se vencer (probabilidade que pode ela própria depender do quanto é gasto) e de como os custos do litígio são distribuídos entre quem ganha e quem perde a causa. Custas judiciais elevadas, advogados caros e juízes corruptos tendem a encorajar as partes a usarem mecanismos alternativos de resolução de disputas ou simplesmente a não iniciarem um litígio. Uma tensão adicional entre justiça e eficiência surge, ainda, da necessidade de se dar oportunidades adequadas de recursos e, ao mesmo tempo, garantir resoluções com presteza e a custos baixos.

As decisões são previsíveis quando a variância ex-ante do ganho líquido de custos é pequena do ponto de vista das partes. Vale notar que essa variância é formada tanto pela variância do resultado em si (i.e., perde ou ganha), como do tempo necessário para se alcançar uma decisão. Ambas representam fatores indesejáveis e atuam como desincentivos para se recorrer ao judiciário. A previsibilidade é alta quando a probabilidade de se vencer é próxima de zero ou um e a variância do tempo gasto para se tomar a decisão é pequena. Os tribunais podem ser imprevisíveis porque as leis e/ou contratos são escritos precariamente, porque os juízes são incompetentes ou mal informados, ou porque as partes se mostram inseguras em relação ao tempo que será necessário aguardar até que uma decisão seja tomada. Métodos alternativos de resolução de conflitos podem ser preferidos, consequentemente, não só porque são mais rápidos, mas também porque os árbitros podem estar mais bem preparados para interpretar a questão em disputa. Casella (1996, p.157), por exemplo, observa que, apesar de cara, a utilização da arbitragem no comércio internacional é bem vista pelos negociantes porque "os árbitros são considerados mais competentes e confiáveis do que os tribunais,... um importante aspecto da arbitragem é a possibilidade de ter julgamentos altamente especializados".

Um sistema de resolução de conflitos caracteriza-se como justo quando a probabilidade de vitória é próxima a um para o lado certo e a zero para o lado errado. A parcialidade é claramente ruim, e difere da imprevisibilidade porque distorce o sentido da justiça de uma forma intencional e determinista. Os tribunais podem ser tendenciosos devido à corrupção, por serem politizados (favorecendo a certas classes de litigantes, como membros da elite, trabalhadores, devedores, residentes, etc.), ou por não gozarem de independência em relação ao Estado, curvando-se à sua vontade quando o governo é parte na disputa. ${ }^{8}$

No modelo apresentado no Apêndice, um método ágil de resolução de disputas apresenta um baixo tempo esperado até que uma decisão seja tomada. Quando a justiça é lenta, o valor esperado do ganho ou da perda das partes será tão mais baixo quanto maior for a taxa de juros. O insucesso em se produzir decisões com presteza é frequentemente citado como um importante problema dos sistemas judiciais em todo o mundo. Isto, por sua vez, causa dois tipos de problemas inter-relacionados. Por um lado, a morosidade reduz o valor presente do ganho líquido (recebimento esperado menos os custos), significando que o sistema judicial só em parte protege os direitos de propriedade. Em economias com inflação alta, se os tribunais não adotarem mecanismos de indexação adequados, o valor do direito em disputa pode despencar para zero com bastante rapidez. ${ }^{9}$

Por outro lado, a demora em se alcançar uma decisão funciona como um incentivo para que a parte faltosa opte por iniciar um processo judicial,

\footnotetext{
${ }^{8}$ Este é o caso, por exemplo, na Rússia, onde os tribunais de Arbitrazh são geralmente tidos como imparciais, exceto quando o governo é parte no litígio (Ryterman et al., 1996).

${ }^{9}$ Mesmo em economias com baixa inflação, a perda resultante da morosidade pode ser importante. Em um artigo sobre a necessidade da reforma judicial na Inglaterra, a revista The Economist (1996) observa que, "no presente, companhias de seguro, em particular, arrastam litígios por anos, sabendo que o valor da causa está sendo corroído pela inflação".
} 
evitando sistemas mais rápidos de resolução de conflitos, contribuindo dessa forma para um acúmulo ainda maior de casos no judiciário. Neste sentido, diante de altas taxas de juro e de um judiciário lento, o "lado correto" será desincentivado a recorrer aos tribunais, mesmo quando diante de uma alta probabilidade de ganhar a causa. Tal situação criará fortes incentivos para que o "lado errado" recorra aos tribunais - por exemplo, quando companhias apelam contra o pagamento de impostos, mesmo com poucas chances de vitória. Vale notar, no entanto, que se a morosidade é o único problema, pode-se desencorajar esse tipo de conduta penalizando a parte perdedora (por exemplo, fazendo-a pagar integralmente os custos do litígio).

Nas figuras de 1 a 4, usamos uma versão simplificada do modelo descrito no Apêndice para mostrar como a utilidade de recorrer ao judiciário muda com a probabilidade de vitória (p), para diferentes valores na taxa de juros (i) e com a probabilidade de que a decisão seja tomada em cada período (q) (ver seção A.1.2. do Apêndice). Já que no modelo simplificado a utilidade $(\mathrm{U})$ é proporcional ao valor em disputa $(\mathrm{V})$, podemos assumir, sem perda de generalidade, que $\mathrm{V}=\$ 1$. Em todas as figuras, a linha (reta) mais ao alto reflete o caso de um agente neutro ao risco, e as linhas abaixo dessa indicam agentes crescentemente avessos ao risco.

Agentes neutros (i.e., indiferentes) em relação ao risco não são afetados pela falta de previsibilidade do judiciário, de maneira que podemos nos concentrar nas linhas retas do topo para entender os efeitos da morosidade, dos custos e da imparcialidade. Vale notar que a escala do eixo vertical varia de uma figura para outra, o que reflete o fato de que mesmo quando há certeza de que se vai ter ganho de causa $(\mathrm{p}=1)$, a utilidade de recorrer ao judiciário é tão menor quanto maiores forem a taxa de juros e o tempo esperado até o momento de se chegar a um veredicto (baixo q). No caso menos favorável dos quatro aqui considerados, no qual $\mathrm{q}=0,1 \mathrm{e} \mathrm{i}=$ $20 \%$, um agente neutro em relação ao risco teria um ganho líquido esperado, em termos de valor presente, de somente $\$ 0,32$. A morosidade, no entanto, não afetaria a decisão de um agente de iniciar ou não um litígio, já que sua utilidade seria positiva mesmo para baixos valores da probabilidade de vitória. Note-se, porém, que enquanto i e q determinam a inclinação da curva, seu intercepto é igual ao valor dos custos de litígio, com sinal negativo, medido como proporção do valor em disputa (c). Ao se compararem as figuras 2 e 3, é possível constatar que, mesmo para valores não muito altos de $\mathrm{p}$, a probabilidade de se ganhar um mecanismo rápido de resolução de conflitos, ainda que com custos altos, pode ser preferível a um mecanismo moroso com baixos custos. $\mathrm{O}$ grau de imparcialidade e o valor dos custos de litigar são determinantes óbvios da decisão de iniciar ou não um litígio.

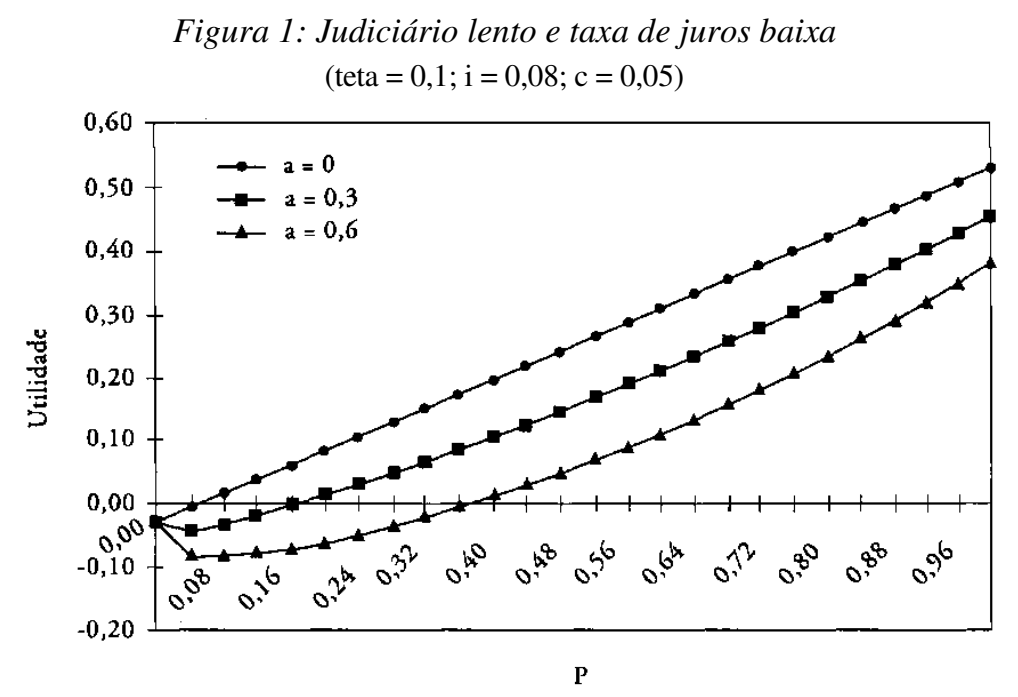

Quando o judiciário não é previsível, "p" acha-se perto de 0,5 e/ou a variância da duração do litígio é alta, o que reduz a utilidade de se apelar para os tribunais. $\mathrm{O}$ efeito da imprevisibilidade das decisões sobre a utilidade pode ser avaliado na Figura 2. Nesse caso, porque q é grande, a duração esperada do litígio e a incerteza sobre quanto tempo será preciso esperar até uma decisão são relativamente pequenas, de maneira que as diferenças verticais entre as curvas refletem essencialmente a "desutilidade" ou "ônus" que resulta da incerteza sobre o teor em si das decisões judiciais. No caso de agentes muito avessos ao risco, este pode ser um determinante importante para não se iniciar um litígio. Como ilustrado pela linha inferior da Figura 2, um agente avesso ao risco obrigado a incorrer em custos de $5 \%$ do valor em disputa não iria recorrer à justiça se não tivesse ao menos $33 \%$ de chance de vitória. Para se avaliar o impacto da incerteza quanto à duração do litígio (no modelo, representada por $\operatorname{Var}(\mathrm{T})$ ), compare as Figuras 1 e 2, no ponto $\mathrm{p}=1$. Na Figura 2, na qual $q=0,8$, a aversão ao risco não é um fator importante, mas na Figura 1, na qual q = 0,1, a utilidade do agente mais avesso ao risco é substancialmente menor do que a do agente neutro $(\$ 0,38$ contra $\$ 0,53)$. 
Figura 2: Judiciário rápido e taxa de juros baixa (teta $=0,8 ; \mathrm{i}=0,08 ; \mathrm{c}=0,05$ )

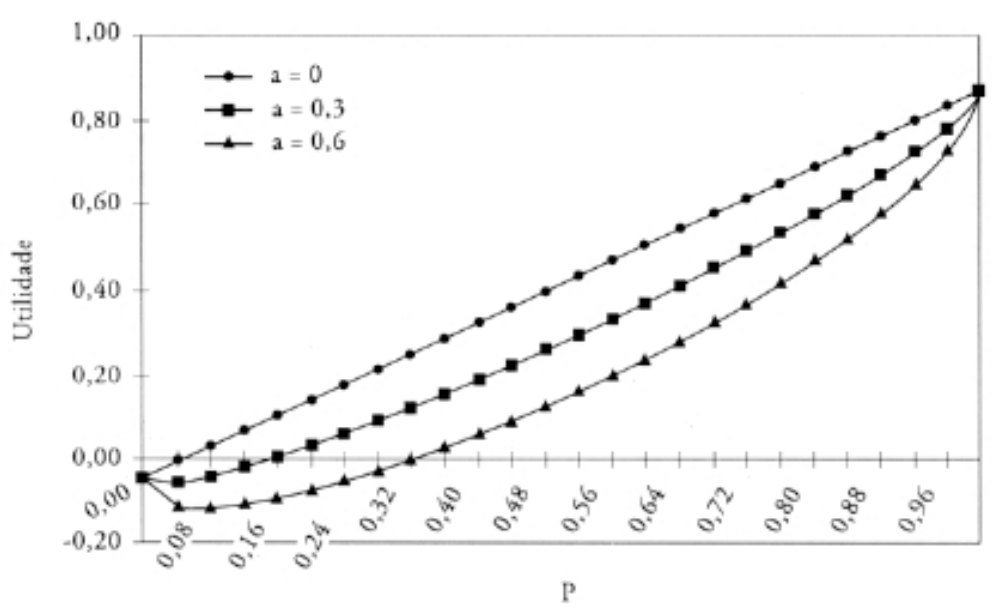

Figura 3: Judiciário lento e taxa de juros baixa (teta $=0,1 ; \mathrm{i}=0,2 ; \mathrm{c}=0,05)$

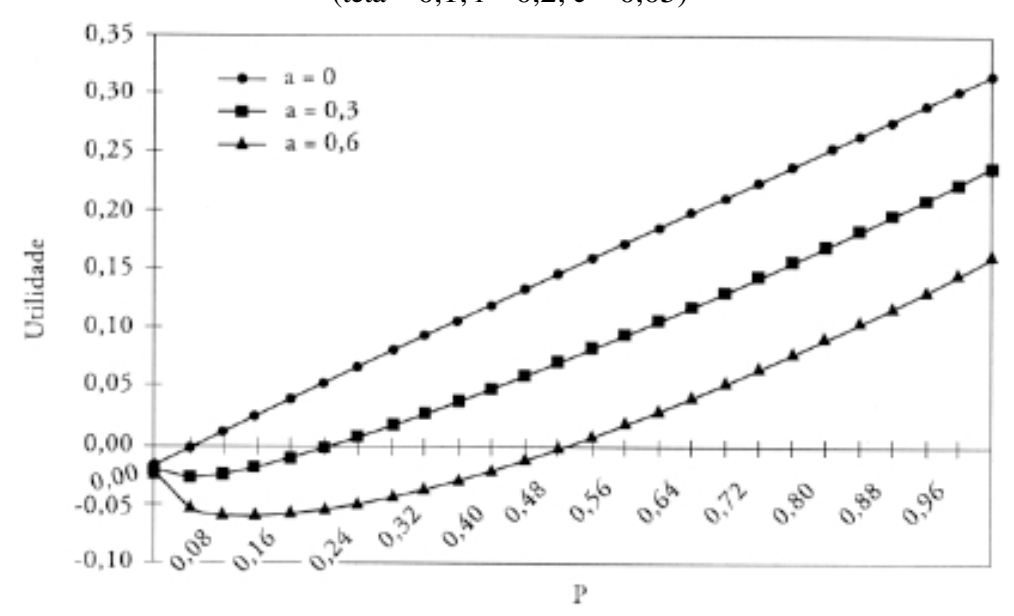

Figura 4: Judiciário rápido e taxa de jutos alta (teta $=0,8 ; \mathrm{i}=0,2 ; \mathrm{c}=0,05$ )

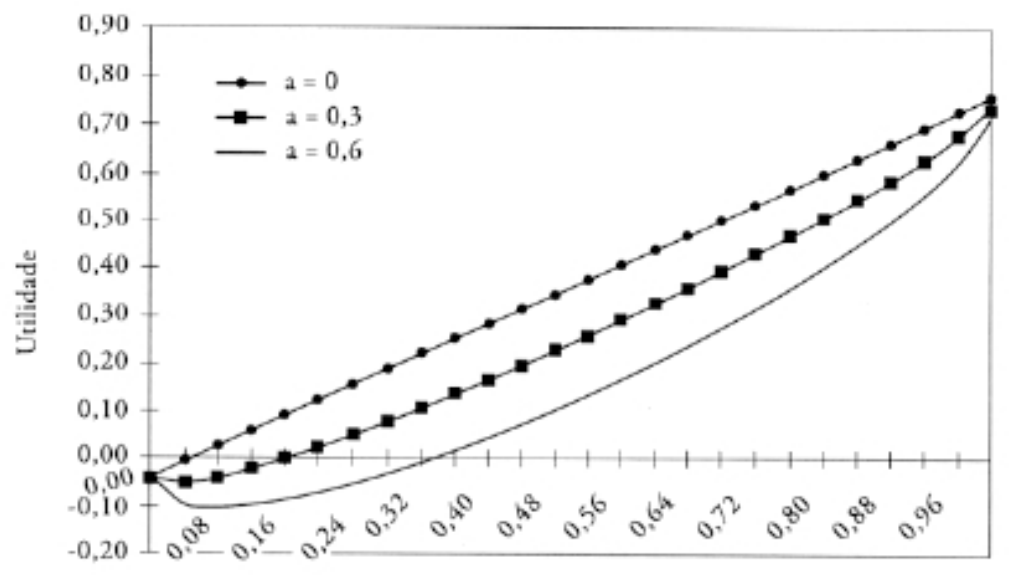

$\mathrm{P}$

Ao lado disso, do ponto de vista da parte situada do "lado certo" da lei, ou seja, daquele que deveria receber $\mathrm{V}$, um valor de " $p$ " próximo a 0,5 implica um ganho esperado abaixo do que essa parte teria direito a receber. O mesmo acontece se $\operatorname{Var}(\mathrm{T})$ é grande, mesmo para valores altos de "p", já que nesse caso há grande possibilidade de o valor presente do ganho, se ocorrer, acabar sendo pequeno (ou seja, tribunais imprevisíveis são também tribunais injustos). Do ponto de vista da "parte errada", no entanto, essas são características que estimulam o uso dos tribunais. Significam que iniciar um litígio corresponde a trocar um pagamento certo por uma loteria, com a possibilidade de ganhar também, mesmo que a decisão lhe seja desfavorável, caso esta seja tomada em um futuro muito distante. Dessa maneira, medidas que tornem os tribunais mais previsíveis - tais como dar maior homogeneidade às decisões dos juízes e aumentar a informação nelas contida - diminuem os incentivos para as partes erradas litigarem. Uma outra maneira de produzir esse desincentivo consiste em estabelecer custos altos para a parte que perde a causa. Se a falta de previsibilidade resulta somente da incerteza sobre a duração do litígio, uma penalização suficientemente alta imposta à parte perdedora será o bastante para desencorajar o "lado errado" a litigar, não afetando ao mesmo tempo significativamente o "lado correto". No entanto, se a imprevisibilidade resulta parcial ou totalmente de um valor de "p" próximo a 0,5 , tal penalização irá desencorajar ambas as partes de recorrerem ao judiciário. 
O que essa análise mostra é que causas podem ser iniciadas de boa fé (para proteger direitos), mas também por má fé, explorando-se neste caso o mau funcionamento do sistema. Se os tribunais são tendenciosos, isso aumenta a propensão a litigar das partes normalmente favorecidas por essa tendenciosidade. Se os tribunais forem imprevisíveis ou lentos, "as partes erradas" tenderão a litigar em casos frívolos ou de outra maneira injustificáveis. Por exemplo, na concessão do direito de exploração do pedágio da ponte Rio - Niterói, em 1995, a empresa perdedora da proposta foi capaz de adiar a conclusão do processo apelando para instâncias judiciais mais altas, mesmo sabendo não ter chance alguma de ganhar, simplesmente para prejudicar o seu competidor. Lanjouw e Lerner (1996) mostram como o mecanismo das liminares é utilizado "de maneira bem sucedida" por empresas financeiramente fortes para prejudicar empresas mais fracas, levando, desta maneira, as disputas a resoluções que lhes são mais favoráveis. Camargo (1996) mostra como a morosidade e a imprevisibilidade (no que diz respeito à duração) da justiça trabalhista no Brasil estimulam as empresas a não pagarem as contribuições sociais devidas aos empregados, optando por resolver a questão mais tarde nos tribunais. Embora a Justiça do Trabalho seja tida como tendenciosa em favor dos trabalhadores, em razão de normalmente demorar muito para tomar uma decisão, os trabalhadores usualmente concordam em encerrar o litígio recebendo um valor inferior ao que em tese teriam direito. Tais resultados ajudam a explicar porque não somente sistemas judiciais tendenciosos, mas também aqueles morosos e imprevisíveis são perniciosos no que diz respeito à justiça e à eficiência.

Hay et al. (1996, p. 561) levantam duas outras questões críticas, principalmente para economias em transição: verificabilidade e completude. ${ }^{10}$

Num sistema legal disfuncional, os tribunais não podem resolver de forma efetiva disputas contratuais, mesmo quando o desejam, por duas razões. Primeiro, por não poderem verificar facilmente se houve ou não uma violação. Por exemplo, na ausência de métodos uniformes de contabilidade, os tribunais se veem impedidos de verificar se um sócio roubou de outro na joint venture de ambos. Segundo, porque não há corpo de lei que especifique o que um tribunal deve fazer quando há uma violação. Por exemplo, o direito russo não especifica quem é responsável quando um comprador de títulos descobre que esses títulos haviam sido previamente roubados (não existem regras que garantam bona fide ao comprador).

Obviamente, a capacidade dos tribunais de fazer com que suas decisões sejam cumpridas é um outro requisito para que um sistema judicial funcione bem. O cumprimento de tais decisões depende do poder de coerção do Estado, mas também das normas sociais e da qualidade da lei, tanto no que diz respeito à transparência, como ao fato de ser percebida como justa. Como ocorre com a resolução em si de conflitos, se o sistema judicial não consegue garantir a aplicação de suas decisões, as partes podem recorrer a mecanismos privados para fazê-lo ou simplesmente optar por não litigar. Na Rússia, por exemplo, "métodos privados de garantir o cumprimento de acordos são comuns, com os custos econômicos e sociais associados" (Ryterman et al., 1996, p. 2). O Banco Mundial (1996, p. 93) nota ainda que:

Mesmo quando se chega a veredictos, os vencedores podem enfrentar dificuldades em vê-los cumpridos. No Vietnam, por exemplo, menos de 40\% das decisões tomadas pelos tribunais, em 1993 e 1994, foram efetivamente aplicadas, enquanto, na Rússia, metade das sentenças emitidas pelos tribunais é, em geral, descumprida. Esses fatores, combinados com atitudes culturais arraigadas em relação à lei, ajudam a explicar o porquê de empresas privadas evitarem os tribunais para resolverem disputas, particularmente no Leste Asiático e nos NIS (Novos Estados Independentes).

Alguns autores observam, no entanto, que as leis e sentenças judiciais, mesmo na ausência de mecanismos estatais capazes de impô-las completa e generalizadamente, oferecem orientações que os agentes econômicos podem utilizar para estruturarem suas transações e fazerem valer privadamente seus contratos. Na mesma direção, Cooter $(1996$, p.5) sublinha a importância das normas sociais e a percepção da equanimidade das leis como alternativas à coerção estatal:

À medida que a economia se desenvolve e cresce em complexidade, as autoridades precisam de mais informação para aplicar a lei, e os cidadãos, mais informações para obedecê-la. Moldando-se às normas sociais, a lei estatal reduz a importância das restrições informacionais e motivacionais... As leis fazem sentido para os cidadãos, e as autoridades podem contar com a sua cooperação e com os seus esforços informais para que elas sejam aplicadas.

\footnotetext{
${ }^{10}$ Ver também La Porta et al. (1996 e 1997).
} 
Os tribunais russos de Arbitrazh exemplificam uma situação na qual a implementação das leis depende mais de normas sociais do que do poder coercitivo do Estado. Ryterman et al. (1996, p. 5) mostram que, embora os tribunais de Arbitrazh não disponham de poderes para a aplicação da lei, as empresas russas dependem amplamente de tais tribunais:

\begin{abstract}
As sentenças dos tribunais de Arbitrazh parecem ser interpretadas como delineamentos dotados de credibilidade sobre que empresas estão erradas (...) Assim, as decisões dos tribunais de Arbitrazh são percebidas, de maneira geral, como legítimas, o que talvez explique o porquê de tais sentenças muito frequentemente serem autoaplicáveis e o porquê de a simples ameaça de se recorrer aos tribunais poder resolver conflitos.
\end{abstract}

\subsection{COMO OS SISTEMAS JUDICIAIS AFETAM O CRESCIMENTO ECONÔMICO?}

\subsubsection{Uma perspectiva tecnológica}

Uma primeira abordagem à questão colocada no título desta seção consiste em analisar como o funcionamento do judiciário afeta a expansão da capacidade de produção da economia. Para isso, é necessário ter-se em conta que só há duas maneiras de se expandir a produção: ou aumentando a quantidade de insumos utilizada, ou elevando a produtividade com a qual esses insumos são empregados. O crescimento deste segundo componente, a produtividade total dos fatores, pode, por sua vez, resultar tanto do progresso tecnológico como do aumento da eficiência com que a tecnologia disponível é utilizada. Dessa maneira, se se quer entender porque alguns países são pobres e outros ricos, ou porque alguns crescem mais do que outros, é sobre esses componentes que se deve centrar a atenção. Consequentemente, os três aspectos que vamos considerar para avaliar como judiciários eficientes podem beneficiar o crescimento econômico são o progresso tecnológico, o investimento e a eficiência. A seguir, examinamos cada um desses aspectos individualmente.

\section{Progresso tecnológico}

Bons sistemas judiciais e legais podem estimular o crescimento protegendo a propriedade intelectual, com isso encorajando a absorção e o progresso tecnológicos. ${ }^{11}$ Há duas maneiras pelas quais isso pode ocorrer, uma a partir da oferta, outra da demanda por tecnologia.

A proteção à propriedade intelectual facilita a compra de tecnologia de países industrializados - tecnologia esta incorporada ou não em bens de capital - ao mesmo tempo em que encoraja as empresas situadas no país a investirem em pesquisa e desenvolvimento. Algumas evidências desse efeito são fornecidas por Gould e Gruben (1996), que utilizam regressões com cross-section de países para analisar o impacto sobre o crescimento da proteção à propriedade intelectual, controlando o efeito de diferenças no regime comercial e em outras características de cada país. Os resultados sugerem que países que protegem adequadamente a propriedade intelectual crescem mais rapidamente do que aqueles que não o fazem, e ainda que esse efeito seja levemente mais pronunciado em economias abertas. Na mesma linha, Mansfield (1994 e 1995) apresenta evidência empírica segundo a qual a qualidade do sistema de propriedade intelectual de um país qualquer parece influenciar sua habilidade em atrair investimento e tecnologia norteamericanos, alemães e japoneses para indústrias de alta tecnologia. ${ }^{12}$

Em segundo lugar, a implementação com presteza e consistência dos contratos privados reduz os custos de transação e estimula os agentes econômicos, a um só tempo, a aumentarem o número de transações em que se engajam e a dispersarem-nas geograficamente.

Isso, por seu turno, leva a uma difusão mais ampla do conhecimento, incluindo não somente o conhecimento tecnológico, mas também o de práticas adequadas de gerenciamento, marketing e finanças. À medida que o tamanho do mercado aumenta, as empresas enfrentam uma competição mais dura, mas, por outro lado, também são capazes de auferir maiores lucros e vendas a partir

\footnotetext{
${ }^{11}$ Curiosamente, essa questão é considerada de pouca importância por Olson, para quem "o conhecimento produtivo do mundo está, em grande parte, acessível aos países pobres, e mesmo a um custo relativamente modesto. Seria muito difícil explicar as diferenças de renda per capita entre os países em função do acesso diferenciado ao estoque disponível de conhecimento produtivo". [Olson (1996, p.8)].

${ }^{12}$ Essas conclusões não são, obviamente, isentas de controvérsia. Helpman (1993), por exemplo, usa uma diferente metodologia para mostrar que, enquanto direitos estritos de propriedade intelectual podem promover o interesse dos países industrializados, esses nem sempre beneficiam os países em desenvolvimento.
} 
de uma mesma inovação. Estes dois efeitos tendem a encorajar a inovação, seja pelo desenvolvimento, seja pela aquisição de tecnologia. ${ }^{13}$

\section{Investimento}

Uma outra maneira pela qual um bom judiciário pode acelerar o crescimento é estimulando a acumulação de fatores de produção. Em particular, os agentes econômicos investem mais em capital físico e humano quando os seus direitos de propriedade são garantidos por bons sistemas judiciais e legais e por um regime político estável (Schmidt-Hebbel et al., 1996; Alesina e Perotti, 1994). Um caso típico é aquele de direitos que dependem diretamente da proteção do Estado, como a propriedade da terra, a propriedade intelectual e o direito de se explorar recursos minerais e outras concessões públicas. Nesses casos, a precária observância dos direitos de propriedade e o risco de expropriação, por agentes públicos ou privados, reduzem o valor dos ativos, o retorno esperado sobre novos investimentos e, consequentemente, a propensão a se fazerem novas inversões. Sistemas judiciais disfuncionais podem também desencorajar a poupança e estimular a evasão de capital, reduzindo o volume de fundos disponíveis para se financiar o investimento.

Como observado por Willianson (1995, p. 182), o impacto de sistemas judiciais sobre investimento em capital físico e humano será tão maior quanto mais especializada e específica for a natureza desse investimento:

Nações em que há graves riscos ao investimento irão gerar quantidades menores de investimento especializado e durável (...) diferentemente de regimes de proteção ao investimento com maior credibilidade; nações com judiciários problemáticos sofrerão desvantagens da mesma natureza. Essa tendência aparecerá claramente no que diz respeito à tecnologia. Regimes que dão poucas garantias ao investimento e à contratação raramente serão capazes de fornecer garantias seguras aos direitos de propriedade intelectual. Indústrias de alta tecnologia ou que se beneficiam de investimentos duráveis e especializados irão abandonar regimes marcados por enormes inseguranças no que se refere a contratos e a investimentos - por lugares mais seguros.

\footnotetext{
${ }^{13}$ Os mecanismos em funcionamento aqui são similares àqueles discutidos por Grossman e Helpman (1992, particularmente capítulo 9) no contexto do comércio exterior
}

Makler (1996) explica, a partir do trabalho de Williamson (1985), a razão para essa tendência. Os agentes privados só irão fazer investimentos de longo prazo, altamente especializados, se estiverem seguros que os contratos que garantem suas atividades serão corretamente implementados. Dado que a produção especializada frequentemente requer ativos específicos a uma transação, ${ }^{14}$ contratos nessa área são em geral afetados pela capacidade das partes renegarem o que foi previamente acordado entre elas. Restrições legais podem também limitar a habilidade das partes para disporem livremente de seus ativos. Em contratos de longo prazo, por outro lado, é difícil para os envolvidos antecipar e elencar à época do contrato todas as contingências passíveis de ocorrerem durante a sua vigência. Por não serem previsíveis ou por exigirem custos elevados para serem devidamente contempladas no contrato, as contingências devem ser equacionadas na medida em que surjam, requerendo das partes envolvidas o exercício de algum grau de discernimento durante a execução do contrato. Hay et al. (1996) observam que os contratos também podem ser incompletos se contemplarem cláusulas que os tribunais não podem verificar e regular.

Em todos esses casos, uma ou ambas as partes terão incentivos para agir de forma oportunista, i. e., promover seu interesse próprio astuciosamente: "Enquanto é razoável esperar que as partes persigam seu próprio interesse.., o componente de astúcia refere-se à propensão de uma parte ab-rogar ou retirar-se da barganha original na busca de seu interesse individual”. (Makler, 1996) Bons sistemas judiciais, aí incluída a condição de que os contratos sejam bem elaborados e que existam métodos de contabilidade que permitam a sua verificação pelos tribunais, são essenciais para se reduzirem os riscos contratuais. Sobretudo quando o Estado é parte do acordo, judiciários fortes e independentes são essenciais para estimular atividades econômicas que envolvam investimentos específicos.

Os estudos de países sumariados em Levy e Spiller (1994) claramente indicam que, em setores com investimentos específicos, um bom judiciário é uma condição necessária para a participação de investidores privados. Em países onde o judiciário é fraco, as leis instáveis e o arbítrio governamental algo comum, investimentos nesses setores só tendem a ocorrer quando

${ }^{14}$ Entende-se por ativo ou investimento específico uma aplicação de capital cujo aproveitamento em outra atividade é impossível ou, se realizada, implica em grande perda de valor. Para uma discussão mais aprofundada sobre a especificidade de ativos ver Williamson (1985). 
efetuados diretamente pelo Estado. Dessa forma, sistemas judiciais que funcionam mal geram ou a falta de investimentos, ou uma produção estatal cuja eficiência é usualmente mais baixa que a do empresário privado. $\mathrm{O}$ setor de telecomunicações, como exemplificado por Levy e Spiller (1994, pp. 218-9), ilustra bem o problema:

O estabelecimento de uma rede de telecomunicações envolve largas somas de investimentos afundados, porque os bens investidos têm valor alternativo ou possibilidade de recuperação muito baixos. Consequentemente, os serviços públicos se mostram particularmente vulneráveis à expropriação pelo setor público, com os reguladores fixando preços abaixo dos custos de reposição de longo prazo, de forma a capturarem as quase-rendas (retornos acima do custo de oportunidade quando um bem se acha temporariamente com oferta escassa) associadas com a operação desses ativos. As empresas terminam com incentivos para investirem menos do que o ótimo do ponto de vista social.

Na seção A.2 do Apêndice, desenvolvemos um modelo simples que ajuda a entender a importância de um bom sistema judicial para estimular o investimento em casos nos quais a especificidade dos ativos é alta. O modelo mostra que na presença de ativos específicos e do oportunismo dos agentes, os tribunais podem ajudar a reduzir as taxas de retorno exigidas pelos investidores, em muitos casos viabilizando projetos que de outra maneira não ocorreriam. $\mathrm{O}$ modelo leva naturalmente à conclusão de quanto mais eficiente o judiciário menor a taxa de retorno requerida e maior a demanda por investimento.

\section{Eficiência}

Finalmente, sistemas judiciais que funcionam mal atrapalham o crescimento ao estimularem um uso ineficiente de recursos e de tecnologia, distanciando os países das melhores práticas de produção. Assim, os altos riscos e custos de transação ocasionados pelo mau funcionamento da justiça afastam o sistema de preços do país dos padrões internacionais, distorcendo a alocação de recursos. Além disso, quando os contratos e os direitos de propriedade não são apropriadamente garantidos, as empresas muitas vezes optam por não desenvolver certas atividades, deixam de especializar-se e explorar economias de escala, combinam insumos ineficientemente, não distribuem a padrão da forma mais eficiente entre clientes e mercados, mantêm recursos ociosos etc. A eficiência também pode ser afetada se o fraco desempenho do judiciário segmentar o mercado a ponto da reduzir significativamente a competição.

Na seção A.3 do Apêndice, desenvolvemos um modelo que ajuda a entender o impacto do mau funcionamento do judiciário sobre o sistema de preços e, como consequência, sobre a eficiência econômica. No modelo, uma firma vende para dois tipos de clientes. $\mathrm{O}$ cliente de tipo 1 respeita o contrato e paga o preço acordado. Já o cliente de tipo 2 age de forma oportunista e a firma se vê obrigada ou a recorrer aos tribunais, ou a renegociar o contrato, recebendo apenas uma parcela do lhe é devido. Porque a firma não sabe discernir ex-ante quais clientes são do tipo $1 \mathrm{e}$ quais do tipo 2, ela adiciona um prêmio de risco ao seu preço, o que distorce o sistema de preços e reduz a eficiência alocativa. Quanto mais eficientes os tribunais, menos um cliente irá ganhar por desrespeitar o contrato, e menor a quantidade de clientes tentados a fazê-lo. Isso, por sua vez, irá reduzir o prêmio de risco e a ineficiência alocativa.

Embora o modelo identifique na firma a parte que se vê expropriada, não é necessário que seja sempre esse o caso. De fato, especialmente em países em desenvolvimento, os produtores quebram os contratos com frequência. Empresas vendem bens que não apresentam as qualidades anunciadas, concessionárias privadas fornecem serviços que não atendem a todas as especificações do contrato de concessão, etc. Porque o litígio implica custos altos, os consumidores e/ou o governo podem se decidir por não processar judicialmente a empresa. Klein e Leffler (1981) desenvolvem um modelo que mostra que no caso de transações repetidas e em estruturas de mercado não monopolistas, o autocumprimento dos contratos é possível, se os consumidores se comunicam a custos baixos e se o preço é suficientemente alto. Nesse caso, a firma ganha uma renda - na forma de um prêmio sobre o preço que iria prevalecer no caso em que uma terceira parte garantisse o cumprimento perfeito do contrato - que é perdida no caso da quebra do contrato, e que funciona, portanto, como um incentivo para a autoaplicação do contrato.

Um outro caminho pelo qual sistemas judiciais disfuncionais reduzem a eficiência da economia é através do consumo direto de recursos escassos. Litígios requerem advogados, o tempo e a atenção das partes, e um judiciário bem aparelhado. Trata-se de serviços altamente especializados, e a sociedade 
tem de gastar recursos consideráveis para treinar e formar juízes, advogados e outros quadros envolvidos no litígio. Há três fontes adicionais de ineficiência. Primeiro, o custo dos agentes privados em manter-se atualizados sobre a complicada e mutável legislação que tende a substituir o bom funcionamento dos sistemas judiciais. $\mathrm{O}$ setor público também se vê frequentemente obrigado a manter uma ampla burocracia para processar e supervisionar a aplicação dessa legislação. Segundo, sistemas judiciais disfuncionais, especialmente quando inclinados a emitir sentenças politizadas, estimulam as partes interessadas a desenvolver estratégias de lobby e rent seeking. Terceiro, os agentes econômicos consomem recursos para desenvolver e utilizar os mecanismos privados que substituem um bom judiciário ou que servem para solucionar os problemas derivados do seu mau funcionamento, como o frequente descumprimento dos contratos. Firmas gastam recursos para triar clientes e fornecedores. Contratos entre partes privadas e com o governo se tornam ao mesmo tempo mais difíceis de escrever - já que há a preocupação de evitar contingências não previstas e que requeiram a interpretação de uma terceira parte para serem resolvidas - e menos importantes em termos da transação. Ao lado disso, como observado por Sherwood et al. (1994, p. 14), a administração de "contratos é também mais difícil em um sistema com fraca imposição (enforcement) já que há uma pronunciada necessidade de se monitorar de perto o desempenho das partes na ausência da disciplina silenciosa imposta por fortes mecanismos de cumprimento de contratos". Por outro lado, dado que o custo de implementar esses contratos é tão alto, as firmas podem constantemente renegociá-los ou simplesmente abandoná-los se a outra parte não os obedecer. A experiência russa ilustra bem esse ponto (Ryterman et al., 1996, p. 4):

Diversos elementos dos contratos não são implementados... as cláusulas de quantidade e as datas dos contratos parecem ser irrelevantes. De maneira similar, os preços entram nos contratos somente para figurarem como objetos de renegociação ao tempo de sua implementação. Quando um fornecedor demanda um preço mais alto, os consumidores consideram tal demanda uma prática normal. Compradores ora pagam, ora abandonam o contrato. $\mathrm{O}$ recurso aos tribunais por quebra contratual não se afigura como uma possibilidade a ser contemplada nessas circunstâncias.

Na presença de sistemas judiciais e legais disfuncionais, os agentes econômicos podem optar por manter a presente capacidade de produção parcial ou totalmente desativada. Holden e Rajaparitana (1994, p. 51) observam, por exemplo, que:

[No Uruguai] O valor de mercado dos imóveis, quando ocupados, é a metade do que seria obtido, caso se encontrassem desocupados. Há um grande número de unidades residenciais desocupadas em Montevidéu pelo fato de os proprietários não desejarem alugá-las, por medo de não poderem reavê-las sem incorrerem em altos custos. A propriedade imobiliária no Brasil é objeto de uma reclamação similar. É difícil alugar apartamentos no Rio de Janeiro devido a problemas relacionados ao término dos contratos de aluguel.

Os mercados de crédito tendem a ser particularmente afetados, por serem especialmente sensíveis a problemas de seleção adversa e dependentes de uma terceira parte para garantir a aplicação dos contratos. Como observado por Sherewood et al. (1994, p. 15), "mecanismos incertos de implementação dos contratos fazem com que seja difícil receber garantias dadas a empréstimos, dificultando, por extensão, empréstimos comerciais em mercados de capital". Além disso, quando se percebe que o governo influencia os tribunais, as firmas tendem a evitar negócios com o setor público ou a cobrar um preço mais alto caso optem por fazê-lo. Em muitas situações, a dificuldade em fazer cumprir contratos com o governo irá estimular a corrupção de políticos e autoridades e reduzir a competição em licitações públicas.

Um judiciário ineficiente, particularmente um judiciário politizado, pode também ocasionar um uso pouco eficiente de insumos. No Brasil, por exemplo, pelo fato de os tribunais tenderem a favorecer os trabalhadores em disputas com as empresas, estas reagem contratando um efetivo de pessoal menor do que aquele que seria aconselhável se apenas o custo relativo da mão de obra fosse levado em conta. As empresas podem também optar por se instalar em cidades ou estados onde confiam no judiciário, mesmo que outras localizações façam mais sentido sob uma perspectiva puramente econômica. Na mesma direção, sistemas judiciais ruins podem impedir transações mais complexas e obrigar as firmas a se pautarem por formas de comércio bastante ineficientes (Ryterman et al. 1996, p.13):

Uma das mais importantes características da economia russa diz respeito ao fato de os pagamentos se verem dominados por mecanismos cuja implementação implica custos altos... (um deles é) a dependência, por parte das firmas, do pré- pagamento como forma de 
se assegurar o desempenho contratual... (o outro é) o pagamento em produtos. Essa modalidade de pagamento é uma característica institucional que parece ter alcançado proporções epidêmicas na Rússia. Acreditamos que sua alta incidência seja uma consequência direta de mercados financeiros subdesenvolvidos, característica que resultou em taxas de juro muito elevadas, e de um sistema legal subdesenvolvido, no qual a política tributária não é apoiada por instituições e normas sociais apropriadas (...) a participação percentual média reportada de pagamentos através de escambo foi de $40 \%$ em 1996, contra uma proporção de 5\% em 1992.

Uma outra maneira pela qual sistemas legais e judiciais disfuncionais reduzem a eficiência consiste no estímulo à integração vertical das firmas, reduzindo dessa maneira o nível de especialização na economia e impedindo a plena exploração de economias de escala e de escopo. Um exemplo é relatado na análise da experiência russa por Ryterman et al. (1996, p. 15):

Em muitos casos, as firmas são capazes de acomodar o fracasso dos sistemas legal e financeiro alterando as fronteiras de suas atividades. Nós observamos uma tendência das empresas a se integrarem verticalmente para a frente. Firmas que abastecem o mercado consumidor reportam que estão expandindo suas operações na direção de operações de varejo com o objetivo de receberem, com mais certeza, o pagamento por seus produtos.

\subsubsection{Uma perspectiva de política}

Ameaças aos direitos de propriedade e riscos de condutas oportunistas podem ter origem em qualquer ator econômico, político ou social. Assim, para encorajar o progresso tecnológico, a acumulação de fatores e a eficiência, o judiciário deve ser capaz de coibir essas condutas por parte dos agentes econômicos em geral. No entanto, é no papel do sistema judicial em limitar o arbítrio governamental que a maior parte da literatura concentra sua atenção. Essa atuação do judiciário se daria de três maneiras inter-relacionadas: garantindo os direitos de propriedade contra a sua expropriação pelo setor público; reduzindo a instabilidade das políticas e melhorando a sua qualidade; e aumentando a flexibilidade e a credibilidade da política econômica. Tratamos desses pontos em seguida.
Assegurando direitos de propriedade contra a sua expropriação pelo setor público

Dentre os canais pelos quais bons sistemas judiciais e legais estimulam o crescimento, o mais frequentemente citado é o que impede expropriação de direitos de propriedade pelo setor público. O risco de expropriação deriva do fato de que o Estado, como qualquer parte em um contrato, tem incentivos para agir de maneira oportunista. Também como em todo contrato, o risco afigura-se tanto maior quanto mais específico for o investimento exigido da outra parte em cumprimento às suas responsabilidades contratuais. $\mathrm{O}$ que torna o Estado tão especial é o monopólio de coerção legal a ele atribuído pela sociedade, o que aumenta o seu grau de liberdade para mudar unilateralmente os termos do contrato ou não honrá-los, não sendo por isso "punido". ${ }^{15}$ Consequentemente, embora os contratos possam especificar cláusulas destinadas a limitar o oportunismo do governo, as transações com o setor público se veem particularmente dependentes da proteção assegurada por um judiciário independente, que garanta o respeito a essas cláusulas.

Levy e Spiller (1994) tratam de forma exaustiva o problema do risco de expropriação pelo setor público no caso das telecomunicações e dos serviços públicos em geral, áreas nas quais o risco de um comportamento oportunista por parte do Estado é particularmente alto, devido ao caráter específico dos ativos e ao fato de os contratos serem de longo prazo. Com base na análise da experiência de cinco países, os autores concluem que (p. 216): "Uma condição necessária para o investimento privado, sustentado e em larga escala em serviços de utilidade pública, é que a arbitrariedade administrativa de parte do governo possa ser coibida". A este respeito, o estudo expressa duas mensagens chave: por um lado, sistemas judiciais que funcionem bem são necessários para limitar o arbítrio administrativo; por outro lado, não são condição suficiente.

Como assinalado por Coase $(1998$, p. 27), o governo influencia as ações dos agentes econômicos no momento em que promove mudanças na

\footnotetext{
${ }^{15}$ Como observado por Dixit (1996, p. 49), "O poder de coação traz consigo o perigo do seu mau uso. Embora a intenção da constituição seja que tal força, ou a sua ameaça, deva servir ao interesse geral, nada pode garantir que, no momento em que é atribuído a uma agência o monopólio da força do Estado, tal agência não irá se valer desse poder para a promoção de seus próprios interesses".
} 
lei e/ou em sua administração. Neste sentido, a política econômica consiste "na escolha das regras, procedimentos, e estruturas administrativas legais que maximizem o valor da produção". Há, no entanto, dois diferentes níveis em que isso ocorre. Um primeiro, paralelo ao que Levy e Spiller (1994) chamam de regulação de detalhe, compreende as próprias leis, tal qual definidas na primeira seção deste capítulo. Um segundo, semelhante à regulação básica de Levy e Spiller, consiste nas limitações substantivas e processuais utilizadas pela sociedade para tornar as firmas menos vulneráveis à capacidade do governo de mudar as regras "no meio do jogo", fazendo-as mais inclinadas a investir.

Para limitar os incentivos e o grau de liberdade que os governos têm para agir de forma oportunista, os países recorrem a três mecanismos. Primeiro, reduzem a margem de arbítrio com que o Estado pode administrar a lei, estabelecendo os limites na própria lei ou em outra legislação. Segundo, estabelecem regras restringindo a habilidade dos governos de mudarem a lei e os limites por ela impostos. Por fim, criam instituições capazes de impor esses constrangimentos substantivos e processuais sobre a capacidade de arbítrio do governo. Obviamente, nem as restrições constituídas em lei, nem os constrangimentos impostos à habilidade do governo de alterar a lei terão qualquer credibilidade se não forem aplicados por um judiciário forte, imparcial e eficiente. Não surpreende, assim, que Levy e Spiller (1994, p. 233) tenham concluído que "os países cujos sistemas regulatórios limitaram com sucesso o poder dos reguladores, dispusessem de judiciários independentes e bem conceituados".

Uma segunda mensagem chave em Levy e Spiller (1994) é que o bom funcionamento do sistema judicial é uma condição necessária, mas não suficiente para proteger de forma efetiva os direitos de propriedade contra a expropriação pelo setor público. Isso porque se a lei impõe limites insuficientes à margem de arbítrio do governo, ou se não há constrangimentos rígidos à possibilidade de se alterar a lei, resta pouco que os judiciários possam fazer. Uma situação particularmente desfavorável é aquela na qual o executivo é capaz de influenciar amplamente a agenda legislativa, seja por possuir poderes legisferantes, seja pelo fato de o mesmo partido controlar o executivo e o legislativo. Em tais casos, mesmo se o judiciário tentasse impedir a conduta oportunista do governo, este poderia prevalecer simplesmente mudando a lei. Uma importante conclusão dos estudos de caso de Levy e Spiller (1994, p. 230) é, consequentemente, que "empresas privadas encarregadas da prestação de serviços públicos se mostravam dispostas a investir de forma sustentada somente quando os três componentes restritivos funcionavam adequadamente". Esta constatação reforça a observação feita anteriormente sobre a dificuldade de em muitos casos separar a influência do judiciário daquela do sistema legal.

\section{Melhorando a qualidade e reduzindo a instabilidade da política} econômica

A importância de uma política macroeconômica sólida e estável para o desenvolvimento econômico é hoje amplamente reconhecida. ${ }^{16}$ Borner et al. (1992) argumentam, no entanto, que a importância atribuída à instabilidade macroeconômica como obstáculo ao crescimento é excessiva. Em particular, os autores notam que também a incerteza institucional, resultante de políticas econômicas voláteis e altamente arbitrárias, ao desestabilizar as "regras do jogo", desencoraja o investimento e a produção. Além disso, pelo fato de o efeito da instabilidade das políticas sobre o mercado não ser neutro, acaba por distorcer a alocação de recursos e por reduzir os incentivos à especialização. Como discutido acima, um bom sistema judicial contribui para reduzir a instabilidade das políticas ao garantir o cumprimento de compromissos legislativos e constitucionais e ao limitar o arbítrio governamental.

Sistemas judiciais disfuncionais não somente reduzem a estabilidade da política econômica, mas também sua qualidade. Em países nos quais os sistemas legal e judicial não apresentam bom desempenho, a política econômica tende a ser mais intervencionista. Como observado por Gray (1991, p.775), "nos países em desenvolvimento, certas formas de regulação direta e políticas governamentais de intervenção no mercado podem ser interpretadas, pelo menos em parte, como substitutos de um sistema legal independente e em bom funcionamento". Um exemplo desse processo é a ampla presença de empresas estatais em diferentes setores das economias em desenvolvimento. Na maior parte dos casos, essas empresas substituem o

${ }^{16}$ Bleaney (1996) afirma, por exemplo, que "a instabilidade macroeconômica politicamente induzida representa uma importante influência negativa sobre o investimento e o crescimento nos países em desenvolvimento". Uma conclusão interessante que deriva dos resultados de Bleaney é que políticas macroeconômicas sólidas afetam o crescimento essencialmente por elevarem a produtividade do capital, embora não mostrem um claro impacto sobre a taxa de investimento. 
investidor privado, ausente de certas atividades devido à incapacidade do governo de estabelecer um compromisso crível de que o investimento privado nesses setores não será expropriado.

Outro exemplo de uma política econômica de baixa qualidade devido ao mau funcionamento do judiciário aparece na área fiscal. A inconsistente aplicação da lei encoraja a evasão fiscal, que é razoavelmente ampla em muitos países em desenvolvimento. Para manter o nível das receitas fiscais, os governos recorrem a impostos que geram baixas receitas, mas produzem grandes distorções na economia, comprometendo o crescimento econômico sem solucionar a questão fiscal. Some-se a isso o fato de que como nem todos os contribuintes têm a mesma capacidade de sonegar impostos, a aplicação precária da lei também tem um importante impacto distributivo.

\section{Aumentando a flexibilidade e a credibilidade da política econômica}

Os países enfrentam uma escolha básica no momento de se definir quão rígidas devem ser as limitações processuais e substantivas à liberdade de ação do governo. Por um lado, o estímulo do sistema legal ao investimento irá aumentar com a força das restrições impostas ao arbítrio governamental. Pelo fato de a maior parte dos investimentos numa economia se caracterizar por algum grau de especificidade dos ativos, os governos se veem permanentemente tentados a conduzir-se de maneira oportunista. Quanto maior a liberdade facultada à política econômica, maior será o risco da ocorrência desse comportamento. Olhando sob esta perspectiva, as leis devem ser detalhadas, rígidas, de difícil alteração e autocontidas. Por outro lado, pelo fato de as circunstâncias nas quais a economia opera mudarem com o tempo, a política econômica talvez só se mostre eficiente se os governos gozarem de alguma flexibilidade na administração da lei. Em um ambiente marcado por mudanças rápidas e por vezes dramáticas, é necessário um sistema legal que permita uma ampla adaptação a essas mudanças de forma a fazer com que a política econômica goze de um grau de eficiência impossível de ser alcançado em meio a estruturas legais muito rígidas. A flexibilidade excessiva, no entanto, aumenta o risco do oportunismo.

Alcançar um equilíbrio razoável entre esses dois objetivos é, portanto, fundamental para que um país consiga ingressar em uma trajetória virtuosa de desenvolvimento, e daí a importância de instituições independentes capazes de constranger a conduta oportunista do governo e, ao mesmo tempo, permitir-lhe flexibilidade suficiente de adaptação ao ambiente externo. Tribunais fortes e independentes permitem que a legislação, a regulação e os contratos de longo prazo com o governo sejam deixados relativamente em aberto, sem comprometer o investimento, já que os investidores privados sabem que seus direitos serão protegidos. Dessa maneira, um bom judiciário aumenta a flexibilidade da política econômica, sem que os investidores se vejam preocupados com a possibilidade de essa liberdade de ação se ver traduzida em expropriação.

\subsubsection{Circunstâncias atenuantes}

A extensão e a natureza do impacto real da inoperância de um sistema judicial sobre o desempenho econômico dependem de um sem número de fatores complementares: em particular, da disponibilidade de mecanismos alternativos para se assegurar os direitos de propriedade e das características de tais mecanismos no que diz respeito a custo e efetividade. ${ }^{17}$ Mesmo em economias com bons sistemas judiciais, muitas companhias se especializam em coletar e vender informações referentes à capacidade de crédito de pessoas e firmas. À medida que cai o custo de processamento de tais informações, diminui o preço cobrado por serviços dessa natureza, mesmo em países menos desenvolvidos. Tais serviços permitem às empresas "protegerem-se" dos impactos negativos do mau funcionamento da justiça, negociando e firmando contratos de forma ampla e em termos bastante impessoais.

A preocupação em manter uma boa reputação também é um substituto razoavelmente efetivo à existência de uma terceira e capaz parte, para garantir a execução de contratos em setores caracterizados por estruturas de mercado não atomizadas e por transações repetitivas, que reduzem o incentivo ao oportunismo. Obviamente, a existência de um judiciário forte irá fazer com que a autoaplicação dos contratos seja ainda mais efetiva. Sherwood et al. (1994, p. 10) observam que tais mecanismos de proteção a parceiros comerciais e de estímulo à auto- aplicação contratual têm sido identificados em diversos estudos do Banco Mundial e que, em muitos casos, eles fornecem

17 Vale notar que ao mesmo tempo em que esses fatores podem atenuar o impacto de um
judiciário precário sobre o desempenho econômico, podem ser eles próprios o resultado da judiciário precário sobre
inoperância do judiciário. 
alternativas mais baratas para o estímulo à observância da lei do que o recurso ao litígio. $\mathrm{Na}$ mesma direção, mecanismos alternativos se acham também disponíveis para a resolução de disputas, tornando desnecessário o recurso aos tribunais. Como observado por Willianson (1995, p. 182):

A tradição do centralismo legal presume que prescrições eficazes da lei referentes a disputas contratuais estejam em vigor e sejam aplicadas pelos tribunais de maneira sofisticada, informada e a baixo custo.(...) Os fatos, no entanto, se apresentam de outra maneira. A maioria das controvérsias - incluindo muitas daquelas que sob as regras correntes poderiam ser encaminhadas para um tribunal - são resolvidas evitando-se a disputa, pela autoajuda e caminhos semelhantes.

Na seção A.3 do Apêndice, desenvolvemos uma extensão simples do último modelo discutido acima, que ilustra o papel dos mecanismos de proteção e de reputação. Na extensão do modelo, a firma consegue se proteger de maus clientes pagando uma pequena taxa a um bureau de crédito (como, no Brasil, o SPC e a Serasa), reduzindo significativamente, dessa maneira, o número de clientes de tipo 2 em sua clientela. Além disso, pelo fato dos clientes terem conhecimento de que suas ações serão monitoradas pelo bureau de crédito, eles terão um maior incentivo a cumprirem o contrato. Como a firma terá um menor número de clientes do tipo 2, não necessitará embutir um prêmio de risco tão alto em seus preços.

O impacto sobre o crescimento das incertezas criadas por uma má performance do judiciário também depende de como os agentes econômicos reagem a elas. Se isto se der pela elevação dos preços, de maneira a acomodar um prêmio de risco, os custos, embora presentes, tenderão a ser mais baixos do que se os atores econômicos reagissem racionando as quantidades ofertadas. Por exemplo, se os bancos aumentarem os seus spreads no lugar de restringirem o crédito, os recursos tenderão a ser melhor alocados. O impacto efetivo dependerá, obviamente, do critério utilizado para o racionamento e da extensão dos problemas de seleção adversa.

As deficiências do judiciário também terão seu impacto sobre a atividade econômica atenuado se o desempenho das empresas já se achar comprometido por problemas de outra natureza. Em economias com alta inflação, por exemplo, os agentes só se engajarão em contratos de curtoprazo, pouco importando quão independente, imparcial e rápido for o judiciário. Da mesma forma, as empresas podem se integrar verticalmente como resultado de incentivos fornecidos pelas políticas de comércio (por exemplo, substituição de importações), de maneira que, pouco importa quão eficiente se mostre o judiciário, a especialização será limitada. Ou ainda, o investimento e a produção podem estar contraídos como resultado, por exemplo, da falta de infraestrutura, de maneira que o aprimoramento do judiciário terá efeitos reduzidos sobre eles.

North (1991) e Sherwood et al. (1994) chamam a atenção para o fato de que a importância de um bom sistema judicial para a economia também depende do seu nível de complexidade. Economias relativamente pouco sofisticadas se engajam menos em transações intensivas em contratos, se calcam mais em normas sociais e negociam direitos de propriedade que necessitam de menor proteção legal, de maneira que podem apresentar um bom desempenho mesmo na ausência de instituições fortes de garantia à propriedade e à aplicação de contratos. Economias mais complexas, e dentro delas os setores que se engajam em contratos de mais longo prazo, produzem e negociam bens que não são facilmente passíveis de exclusão (isto é, podem ser consumidos simultaneamente por várias pessoas ou empresas) e que podem ser reproduzidos a baixo custo, como programas de computador, por exemplo. Consequentemente, elas aferem maiores benefícios com a presença de sistemas judiciais e legais que funcionem adequadamente.

Finalmente, o como e o quanto sistemas judiciais disfuncionais afetam o desempenho econômico dependem da extensão com que as empresas estatais participam da produção. Em particular, se as empresas privadas operam somente nos setores onde as transações tendem a ser de curto-prazo, o investimento não é específico e os contratos autoaplicáveis são a norma, a eficiência provavelmente será prejudicada, mas a produção ocorrerá. Nesse caso, embora a reforma do judiciário venha a ser essencial para permitir as privatizações, ela não terá grande impacto nos setores nos quais as firmas privadas operam. Há, no entanto, uma importante qualificação: judiciários fracos desencorajam investimento e produção naquelas atividades cujo principal cliente é o Estado. Se as empresas estatais controlam uma parcela significativa da economia, esse problema é magnificado.

De maneira geral, podemos concluir que, embora o bom funcionamento dos sistemas legais e judiciais promova o crescimento, avaliar a extensão desse efeito requer pesquisas empíricas. Voltaremos a essa questão nos dois próximos capítulos. Primeiro, no entanto, vamos revisar a literatura empírica sobre o tema. 


\subsection{EVIDÊNCIA EMPÍRICA}

Na sua conferência sobre organização industrial proferida por ocasião do cinquentenário do NBER, em 1972, Ronald Coase observou, de início, que o curioso em relação à reflexão econômica sobre o tema da organização industrial era exatamente a inexistência dessa reflexão. ${ }^{18}$ Algo semelhante pode ser dito sobre a análise empírica do impacto dos sistemas judiciais sobre o desenvolvimento econômico. De fato, o curioso sobre o tratamento desse tema na literatura empírica é exatamente o pouco que se tem avançado, tendo em conta a reconhecida importância desse tópico.

Embora mais acentuada no caso dos sistemas judiciais, a escassez de investigações empíricas é um problema que afeta todo o campo da economia institucional. Pelo fato de as instituições mudarem tão lentamente e se acharem tão arraigadas na vida social, econômica e política, a medição dos atributos institucionais de um país ou de seu impacto sobre o desenvolvimento econômico não é uma tarefa fácil. Como consequência, embora a economia institucional tenha avançado de forma considerável no fronte teórico, as pesquisas empíricas nessa área têm sido raras. Como observado por Justin Yufu Lin e Jeffrey Nugent (1995, p. 2305), "O calcanhar de Aquiles da Nova Economia Institucional é a dificuldade de fazer testes empíricos...

A maior parte da literatura sobre o impacto das instituições, em geral, e dos sistemas judiciais, em particular, sobre o crescimento baseia-se em regressões com cross-sections de países. O trabalho nessa área usualmente se fundamenta em modelos de convergência condicionada, nos quais toma-se por hipótese que países com baixo capital institucional - e, em particular, sistemas judiciais pouco eficientes - apresentam um PIB per capita de equilíbrio mais baixo e, como consequência, menores taxas de crescimento econômico (ver Barro, 1991; Barro e Sala-i-Martin, 1992, 1995). Muitos dos estudos iniciais na área usaram como proxies da qualidade dos sistemas judiciais e legais medidas de instabilidade política, ou, com menor frequência, a natureza do sistema

\footnotetext{
${ }^{18}$ Coase (1988:58) utilizou um diálogo entre Sherlock Holmes e o inspetor Gregory para ilustrar seu argumento: "Vocês devem se lembrar da ocasião em que Sherlock Holmes chamou a atenção do Inspetor para 'o curioso incidente do cachorro ao anoitecer'. Observação que provocou o seguinte comentário do Inspetor: 'O cachorro não fez nada durante o anoitecer'. Holmes então observou: 'Este foi o curioso incidente'. Eu não pude deixar de me lembrar dessa conversa ao contemplar o estado presente do tema da organização industrial".
}

político. A rationale subjacente a esses exercícios é dupla. De um lado, supõese que a instabilidade política reduza a segurança dos direitos de propriedade. Em particular, espera-se que os sistemas judiciais e legais de países envoltos em guerras, revoluções ou outras formas de transição política violenta, estejam menos aptos a assegurar os direitos de propriedade do aqueles de países não expostos a essa sorte de eventos. De outro lado, supõe-se que os regimes democráticos sejam mais capazes de garantir os direitos de propriedade.

Há um volumoso conjunto de evidências empíricas corroborando a asserção de que a instabilidade política dificulta o crescimento (Alesina e Perotti, 1994). De fato, embora um dos primeiros estudos nessa área, conduzido por Hibbs (1973), tenha detectado um efeito de pequena magnitude da instabilidade política sobre o crescimento, a maior parte da literatura recente tem levado a conclusões na direção oposta (e.g. Barro, 1991; Easterly e Rebelo, 1993). Barro e Lee (1994), por exemplo, medem a instabilidade política usando o número de revoluções (vitoriosas ou não) experimentadas anualmente por cada país, e chegam à conclusão de que ela influencia o crescimento negativa e significativamente, em termos estatísticos e econômicos. Um aumento de um desvio padrão na variável "instabilidade política" reduz o crescimento anual em 0,3 pontos percentuais. Alesina e Perotti (1996) demonstram que a instabilidade política reduz o investimento (e, portanto, o crescimento) e também detectam evidências convincentes de que a distribuição desigual da renda aumenta a instabilidade sociopolítica.

Menos persuasiva é a evidência em favor da hipótese de que a democracia estimula o crescimento. O principal argumento conceitual em favor desse efeito seria o fato de que ditadores não poderiam se comprometer, de forma crível, a não expropriarem os direitos de propriedade. As ditaduras seriam caracterizadas, portanto, por maior incerteza e menor volume de investimentos (North, 1990; North e Wingsat, 1989). A evidência empírica, no entanto, não parece dar lastro a esta hipótese. Como concluem Alesina e Peroti (1994, p. 353), a literatura "referente a esse ponto é absolutamente unânime em achar resultados inconclusivos. Controlando-se pelos determinantes econômicos do crescimento, a democracia não apresenta nenhum efeito sobre o crescimento, seja positivo, ou negativo".

Przeworski e Limongi (1993) examinaram dezoito estudos, com 21 resultados sobre a relação entre desempenho econômico e regimes políticos. 
Cinco desses estudos revelaram não haver relação significativa entre as duas variáveis, oito estabeleceram um nexo entre performance econômica e democracia, e um número igual de estudos mostrou o mesmo vínculo em relação aos regimes autoritários. ${ }^{19}$ Não somente a evidência empírica é inconclusiva, mas, como assinalado por Przeworski e Limongi (1993) e Przeworski (1995), os trabalhos empíricos nessa área sofrem de sérios problemas estatísticos. Em particular, regimes políticos não são variáveis exógenas, como é assumido em diversos desses estudos, de maneira que não se deveria considerar a amostra utilizada nessas regressões como sendo selecionada aleatoriamente.

A ausência de uma relação significativa entre regimes políticos e crescimento não significa obviamente que eles não impactem a segurança dos direitos de propriedade. Há outros fatores ligando crescimento e regimes políticos, tais como a pressão mais baixa por consumo imediato e a autonomia do Estado, que podem pesar a favor de um maior crescimento nas ditaduras. Mas não só não está claro por que deveria ser mais fácil para o Estado estabelecer compromissos mais críveis em regimes democráticos afinal, a história está repleta de democracias de breve duração e de ditaduras que tiveram longa sobrevivência - como também os argumentos usuais falham por não reconhecer que o Estado não representa a única ameaça aos direitos de propriedade:

\begin{abstract}
A literatura sobre direitos de propriedade trata o Estado como a única fonte de ameaça potencial. Mas os direitos de propriedade são ameaçados pelos atores privados: a propriedade capitalista é ameaçada pelos trabalhadores organizados, a propriedade dos senhores de terra, pelos camponeses sem-terra. Não é de maneira alguma claro que o vilão seja necessariamente o "governante". De fato, um dilema liberal consiste no fato de que ao mesmo tempo em que se requer um Estado forte como forma de proteção da propriedade contra invasões privadas, o Estado forte é ele próprio uma potencial ameaça [Przeworski e Limongi (1993, p. 53)].
\end{abstract}

\footnotetext{
${ }^{19}$ De acordo com Prezeworski e Limongi (1993, p. 6), o padrão histórico desses resultados lança suspeitas sobre a influência da ideologia na estatística: "O que é ainda mais intrigante é que entre os onze resultados publicados antes de 1988, oito acharam que regimes autoritários cresciam mais rapidamente, enquanto nenhum dos nove resultados publicados depois de 1987 davam suporte a esta conclusão".
}

Mais recentemente, diversos estudos vêm tentando avaliar o impacto de sistemas legais/judiciais sobre o desenvolvimento econômico, focalizando variáveis mais proximamente relacionadas à segurança dos direitos de propriedade, à estabilidade das políticas e ao desempenho dos sistemas judiciais, e, ao mesmo tempo, superando, pelo menos parcialmente, o problema da endogeneidade. Knack e Keefer (1995), Mauro (1995) e Brunetti e Weder (1995) são autores que seguem esta linha de análise.

Knack e Keefer (1995) se valem de uma série de medidas subjetivas de avaliação de risco de países, geradas por duas instituições privadas e vendidas a investidores internacionais. Os autores concluem que os sistemas legais e judiciais têm impactos maiores sobre a taxa de investimento, o PIB per capita de steady state e a taxa de crescimento do $\mathrm{PIB}$, do que aqueles previamente estimados a partir de medidas alternativas da qualidade do judiciário e das leis, como o grau de violência política ou os índices de liberdades políticas e civis, definidos por Gastil. Um aumento do desvio padrão nos índices de segurança dos direitos de propriedade estabelecidos por Knack e Keefer amplia o crescimento econômico em torno de 1,2 pontos percentuais. Os autores concluem que assegurar os direitos de propriedade é tão importante para o crescimento quanto a educação da população. Knack e Keefer também demonstram que seus resultados são "robustos no que se refere a mudanças no período, no tamanho e na especificação da amostra". Finalmente, os autores evidenciam que a proteção aos direitos de propriedade estimula $o$ crescimento econômico não só por encorajar investimentos, mas também por aumentar a produtividade total dos fatores.

Mauro (1995) utiliza em sua análise nove diferentes índices coletados pela "Business International", uma agência privada de avaliação de risco, compreendendo medidas da estabilidade política e social, da qualidade dos sistemas legais e judiciais, da interferência do governo em atividades comerciais e do grau de corrupção. Os resultados de Mauro (1995) sugerem uma associação negativa e significativa em termos econômicos e estatísticos entre corrupção, de um lado, e investimento e crescimento, de outro. Eles demonstram também que a eficiência governamental exerce um impacto sobre o investimento e o crescimento equivalente àquele produzido pela estabilidade política. 
Brunetti e Weder (1995) examinam de que maneira a instabilidade política afeta o crescimento econômico utilizando dados coletados por 310 firmas, em 28 países em desenvolvimento, por meio de um questionário distribuído especialmente para sua pesquisa. Em particular, o questionário tinha como objetivo obter a avaliação dos empresários sobre questões como “incertezas na legislação tributária, regulações instáveis referentes a contratos trabalhistas, decisões arbitrárias dos tribunais ou procedimentos pouco claros na alocação de todos os tipos de licença". Os resultados indicam que a instabilidade das leis e das políticas reduz as taxas de crescimento econômico. No entanto, a instabilidade na aplicação das leis - medida pelo grau de transparência no processo de aplicação da lei, por um indicador da extensão da corrupção e pelo grau de favoritismo no sistema político - não apresenta nenhum efeito sobre o crescimento. Os autores concluem que enquanto as firmas aparentemente se saem bem ao lidarem com os poderes discricionários dos juízes e dos burocratas, elas não são tão bem sucedidas em equacionar os problemas causados pela incerteza nas leis e nas políticas.

A sugestão de Williamson (1995), de utilizar os padrões de contrato prevalecentes na economia para se avaliar indiretamente o desempenho dos sistemas judiciais, é seguida por Clague et al. (1995). Os autores adotam a proporção de "moeda contratualmente intensiva" (um menos a razão entre o total de papel moeda fora dos bancos e M2) como uma medida da intensidade de transações na economia, que podem requer o recurso ao judiciário para garantir o respeito aos contratos e aos direitos de propriedade. Além disso, assumem que, em função de o investimento depender da eficiente aplicação da lei e dos contratos, países com uma proporção mais alta de moeda contratualmente intensiva (GIM) também deveriam apresentar maiores taxas de investimento e de crescimento. Clague et al. (1995) identificam uma correlação positiva, significativa estatisticamente, entre GIM e o investimento e, em alguma medida, também entre GIM e a taxa de crescimento do PIB. De acordo com as estimativas dos autores, um aumento do desvio padrão em GIM amplia as taxas de investimento em mais de 2,5 pontos percentuais. Finalmente, os autores concluem que CIM afeta o crescimento através de seu impacto sobre o investimento, mas não por meio de efeitos sobre a eficiência.

Muito embora os modelos de crescimento baseados em crosssections de países tenham contribuído para melhorar nossa compreensão sobre como os sistemas legais e judiciais afetam o desenvolvimento econômico, é importante ter consciência das limitações dessa literatura. Quatro problemas em particular merecem atenção.

Primeiro, embora nos últimos anos tenha-se verificado progressos na identificação de melhores proxies, ainda não foi encontrada uma boa forma de medir a qualidade dos sistemas legais e judiciais dos países. Revoluções e outras formas violentas de transição política geram efeitos sobre a oferta de fatores de produção e sua produtividade que se estendem muito além daqueles causados pela insegurança dos direitos de propriedade. Não é muito claro, também, como melhores judiciários poderiam reduzir a instabilidade da política econômica que resulta de "surpresas de impostos inflacionários, taxas de câmbio não previstas e manipulações das taxas de juros". Os indicadores de Borner et al. (1992, p. 17), Knack e Keefer (1995) e Mauro (1995) são criticados por Brunetti e Weder (1995, p. 5), pelo fato de serem extraídos da avaliação de risco soberano preparada por agências de credit rating principalmente para companhias estrangeiras e, que por isso, dão ênfase aos riscos de nacionalização e controles cambiais, não refletindo a percepção dos investidores domésticos. Mais ainda, observam que "as entrevistas com gerentes de firmas multinacionais revelaram uma atitude comum em relação a indicadores de negócios: elas são utilizadas como uma fonte pouco importante de informação".

O indicador de Clague et al. (1995) - equivalente à soma dos depósitos a vista, poupança e pequenos depósitos a prazo em bancos e instituições de poupança- é formado por ativos financeiros com liquidez muito alta para que se possa afirmar com um mínimo de confiança que reflita a importância em uma economia de "transações que requerem a aplicação da lei por uma terceira parte". Ao lado disso, como CIM também reflete a importância da poupança financeira agregada, não é óbvio como se deve interpretar o resultado obtido pelos autores, que pode ser lido como implicando que países com maiores taxas de poupança também apresentam maiores taxas de investimento. ${ }^{20}$

Em segundo lugar, há sérios problemas econométricos na literatura envolvendo a análise cross-section de países. Levine e Renelt (1992) mostram que esse tipo de modelo é muito sensível à especificação utilizada. Um outro problema grave, já mencionado, é a endogeneidade de muitas das variáveis usadas nesses modelos como medidas da qualidade dos sistemas

${ }^{20}$ Para uma discussão desse ponto, ver Clague et al. (1995, pp. 24-25). 
legal/judicial. Quando a endogeneidade é controlada, a significância estatística dessas variáveis cai consideravelmente ou mesmo desaparece. Por exemplo, em Clague et al. (1995), quando o efeito da variável "moeda contratualmente intensiva" sobre o crescimento é estimado utilizando-se variáveis instrumentais, ele deixa de ser estatisticamente significativo. Resultados similares são observados por Besley (1993), cuja conclusão, como assinalada por Justin Yufu Lin e Jeffrey Nugent (1995, p. 2361), vale a pena reproduzir: "o ensaio confirma a ideia que pode haver uma ligação entre direitos de propriedade e investimento, mas também alerta que questões como erros de medida e endogeneidade não podem ser negligenciadas".

Em terceiro lugar, vários desses estudos obtêm resultados que são muito sensíveis à amostra utilizada. A amostragem de firmas usada por Brunetti e Weder (1995), por exemplo, está longe de ser aleatória. ${ }^{21}$ Os autores testaram, a partir da amostra empregada, o impacto da instabilidade política sobre o crescimento, utilizando como medidas dessa variável o número de revoluções e assassinatos e os indicadores de Mauro, derivados de pesquisas com especialistas, obtendo, em ambos os casos, um coeficiente que é "claramente insignificante". Em Clague et al. (1995), a sensibilidade à seleção amostral aparece claramente na Tabela 3. No momento em que as regressões de crescimento são estimadas utilizando-se o conjunto da amostra de 102 países, a variável CIM não aparece como estatisticamente expressiva, em contraste com o resultado obtido utilizando-se 96 países, quando a variável se mostra significante ao nível de 5 por cento.

Vale notar que a sensibilidade à seleção amostral é um problema comum em regressões com cross-section de países, apesar do grande número de observações normalmente utilizadas. Auerbach, Hasset e Oliner (1993) [citado em Pack (1994, p. 57)] mostram que a conclusão de De Long e Summers (1991), segundo a qual o retorno dos investimentos em equipamento ultrapassa o de outras modalidades de investimento, não resiste a uma mudança marginal em sua amostra: "os retornos diferenciados

${ }^{21}$ Os questionários de Brunetti e Weder, dirigidos a empresários do setor privado, foram distribuídos em versões em espanhol e em inglês "da forma mais ampla possível nos países menos desenvolvidos da América Latina, Ásia e África. Foram entrevistados firmas privadas, localizadas em países menos desenvolvidos, nos quais as embaixadas suíças, algumas companhias multinacionais e uma fundação privada de desenvolvimento puderam mediar". É possível que os resultados estejam enviesados em função da forma como as firmas foram inicialmente selecionadas. do investimento em equipamento em relação a outros tipos de investimento pode ser um artefato. Omitindo-se Botswana do conjunto das observações chega-se a coeficientes similares para equipamentos e estruturas". Um outro exemplo é a conclusão de Cukierman e Webb (1995), segundo a qual a independência do Banco Central promove o crescimento (p. 412):

Tomando-se a amostra completa dos países, a substituição não política de diretores dos bancos centrais tem um sinal positivo marginalmente significativo, ao contrário do que se esperava a priori. Porém, Brasil, Coréia e Botswana são "outliers", porque alcançaram alto crescimento apesar da elevada rotatividade de diretores e da alta vulnerabilidade do Banco Central. Com esses países excluídos, o indicador de seis meses de vulnerabilidade apresenta um sinal negativo significativo. Este achado dá suporte à ideia de que, uma vez controlado o efeito de outras variáveis, uma maior dependência política do banco central tende a retardar o crescimento na maioria dos países [a ênfase é nossa].

Em quarto lugar, a qualidade dos sistemas judiciais e legais é apenas uma entre as diversas variáveis que procuram explicar as diferenças internacionais nas taxas de investimento e de crescimento, todas testadas e não rejeitadas a partir de modelos de regressão com cross-sections de países. Diversos estudos mostram resultados igualmente significativos explorando explicações relacionadas ao comércio exterior (e.g. Michaely e Jay, 1973; Feder, 1983; Levine e Renelt, 1992; Harrison, 1996), à desregulamentação dos mercados financeiros (Fry, 1982), à independência do banco central (Cukierman e Webb, 1995), à qualidade e à estabilidade das políticas macroeconômicas (e.g., Kormendi e Meguirre, 1985; Ramey e Ramey, 1995; Bleaney, 1996), ao perfil do investimento (De long e Summers, 1991), e à participação do Estado na produção (Yoder et al., 1991 e Plane, 1992). Embora todos eles rejeitem a hipótese de que suas respectivas explicações não sejam significativas, com exceção de um único estudo, eles não testam a potência de seus respectivos argumentos em relação a hipóteses concorrentes. O problema com essa literatura é bem resumido por Levine e Renelt (1992, p. 959):

Cada um desses estudos usa uma variedade de artigos teóricos para justificar a utilização de diversas variáveis econômicas em regressões de crescimento com cross-sections de países. Embora cada estudo apresente individualmente resultados atraentes, eles se valem de diferentes variáveis explicativas (...) este estudo avalia de forma sistemática a robustez da correlação parcial entre taxas de crescimento per capita e uma combinação de indicadores econômicos mais ampla 
do que a utilizada em qualquer outro estudo prévio. Nós descobrimos que muito poucas variáveis econômicas estão correlacionadas de forma robusta com as taxas de crescimento de países diversos ou com a razão entre gastos de investimento e o PIB.

Pack (1994) apresenta algumas outras considerações pertinentes sobre os resultados derivados de modelos estimados com cross-sections de países, ressaltando o fato que tais modelos impõem pressuposições bastante rígidas sobre as funções de produção internacionais. Consequentemente, ele alerta que embora as regressões com cross-sections de países ajudem a sistematizar os fatos básicos sobre o crescimento e a indicar quais podem ser os mais importantes, elas não devem ser interpretadas como implicando relações de causalidade. ${ }^{22}$ A necessidade de ter moderação em relação a conclusões desse tipo de modelo também é assinalada por Romer (1994, p. 19): “Ao avaliar diferentes modelos de crescimento, concluí que a observação de Lucas (1988) - de que pessoas dotadas de capital humano migram de lugares em que tal capital é escasso para outros onde ele é abundante - é uma evidência tão poderosa quanto todas as regressões com cross-sections de países combinadas".

Curiosamente, não encontramos nessa literatura estudos baseados em duas outras metodologias que poderiam se mostrar úteis para avaliar os custos econômicos de sistemas judiciais precários. A primeira delas consiste no desenvolvimento de modelos computáveis de equilíbrio geral (CGEs) para uma economia padrão, que poderiam ser utilizados para avaliar o impacto sobre o PIB de uma mudança na qualidade dos sistemas judiciais e legais. Este tipo de metodologia é comumente usado para avaliar o efeito de políticas de comércio (e.g. Srinivasan e Whaley, 1986), para apreciar o impacto da política pública sobre a distribuição de renda (Taylor et al., 1980), e assim por diante. ${ }^{23}$ Para empregar CGEs com o fim de examinar esse tipo de problema, seriam necessários um modelo e uma ideia de como e em que grau melhorias no judiciário afetam a conduta dos indivíduos. Por exemplo, uma melhora do

${ }^{22}$ Em particular, essas regressões não constituem evidência suficiente para levar a conclusões radicais como as de Scully, de que: "O paradigma anglo-americano de homens livres e mercados livres liberou o potencial humano num grau sem paralelo na história. São necessárias evidências para se persuadir aqueles que veem futuro na ampla intervenção do governo na economia. Eu achei tais evidências, e elas apontam majoritariamente em favor do paradigma do liberalismo clássico" (citado em Pzewoski e Limongi, 1993, p. 60).

${ }^{23}$ Ver Gunning e Kuzzer (1995), seção 3, para exemplos de avaliação de políticas utilizando modelos CGEs. judiciário poderia reduzir os spreads das taxas de juro em um ponto percentual, deslocar a demanda por empregos em $10 \%$ etc. Tais efeitos poderiam então ser introduzidos no modelo e utilizados para medir seu impacto total na produção, distribuição de renda etc.

Há três problemas com esse tipo de metodologia. O primeiro concerne à sua complexidade. Esses modelos têm milhares de equações e variáveis, e desenvolvê-los requer um grande volume de dados e esforço de programação. Um segundo problema diz respeito ao fato de que, ao contrário do que ocorre com os modelos de comércio, diversas das elasticidades não podem ser estimadas econometricamente, ainda que possam ser aferidas recorrendo-se a métodos de valoração contingente. Um terceiro problema refere-se à necessidade de se introduzir alguma dinâmica no modelo, para se avaliar adequadamente o impacto da reforma dos sistemas judiciais. De outra maneira, somente ganhos estáticos serão mensurados.

Um caminho de pesquisa alternativo consiste em desenvolver estudos de caso detalhados. Sherwood et al. (1994, p. 18) sugerem, por exemplo, pesquisar a experiência de países que passaram por reformas significativas, como os antigos países socialistas e Hong Kong. Mas mesmo em países onde as transições não têm sido tão pronunciadas, uma análise aprofundada de experiências individuais pode trazer à luz evidências importantes. ${ }^{24}$ Esta é essencialmente a metodologia utilizada no estudo apresentado nos próximos capítulos, nos quais examinamos, em detalhe, os efeitos da ineficiência judicial sobre o desempenho da economia brasileira.

\footnotetext{
${ }^{24}$ A China e um caso exemplar. Como observado por Perkins (1994, p. 3): “À primeira vista, o sucesso da China em atrair o capital estrangeiro é um enigma. Afinal, os investidores tradicionalmente têm mostrado pouca segurança nesse país. A China não dispõe de uma tradição legal sólida. Depois de 1976, o sistema teve de ser reconstruído do nada, e as novas leis não apareciam como proteção confiável contra os 'assaltos' das autoridades sobre os direitos da propriedade estrangeira. Independente de quais fossem os direitos legais de propriedade, era necessário o suporte oficial para se ter acesso a insumos controlados pelo Estado, como eletricidade, comércio externo ou transporte ferroviário.... Depois da crise política causada pelos eventos de Tiananmem, em 4 de junho de 1989, havia razões adicionais para que os investidores estrangeiros esperassem uma reversão no sentido do aumento dos controles burocráticos sobre a economia, e não no sentido oposto. Mesmo assim, o investimento estrangeiro continuou a subir".
} 


\section{O JUDICIÁRIO BRASILEIRO: A AVALIAÇÃO DAS EMPRESAS}

Bolivar Lamounier, Maria Tereza Sadek, Armando Castelar Pinheiro

$\mathrm{E}$ ste capítulo apresenta os resultados de nossa primeira pesquisa com empresas, que teve como principal objetivo conhecer a opinião dos empresários sobre o desempenho do judiciário brasileiro. Para este fim, aplicou-se a uma amostra nacional de firmas, por correio, um questionário, que continha também perguntas sobre a frequência, o tipo de litígios em que essas companhias haviam se envolvido nos três anos anteriores e as formas de resolução dessas disputas.

Mais especificamente, buscamos uma avaliação do desempenho do judiciário em três áreas: entradas; processamento de casos judiciais; e resultados. A primeira área, relativa às entradas, diz respeito ao acesso e à qualidade dos processos que chegam ao judiciário. Refere-se aos "custos" de acesso, isto é, ao grau em que se garante ou não o acesso a todos ao sistema, ao custo em que esse ocorre e à amplitude das questões que chegam ao judiciário. A partir desse ângulo, um sistema judicial efetivo seria aquele caracterizado por baixos custos, que se distinguiria pelo assegurado a todos - de direito e de fato - e, ainda, por desencorajar casos passíveis de serem equacionados fora do sistema judicial.

$\mathrm{O}$ processamento dos casos judiciais refere-se às características das decisões: duração, qualidade, previsibilidade e possibilidade de recurso. Aqui, um sistema efetivo minimizaria a influência de considerações não judiciais e economicamente irrelevantes, e operaria dentro de parâmetros razoáveis de tempo. Os resultados dizem respeito à qualidade e à natureza das sentenças proferidas. Soluções (sentenças) adequadas formam o sistema de jurisprudência que guia futuras decisões e fornece os parâmetros de conduta para os diferentes atores sociais.

A primeira pergunta do questionário pedia uma avaliação sobre o judiciário no que se refere a três de seus principais atributos:
Tendo em vista a sua própria experiência e a de outros empresários no mesmo ramo de atividade, como o $\mathrm{Sr}$, avalia o desempenho do judiciário brasileiro nos seguintes aspectos: agilidade, imparcialidade e custos.

Sobressai claramente da Tabela 2.1 que, aos olhos dos empresários, a morosidade figura como o principal problema do judiciário. Os custos aparecem em segundo lugar, enquanto a imparcialidade é dos três o atributo em que o sistema é melhor avaliado. De fato, é rigorosamente simétrica a distribuição das respostas no quesito imparcialidade, com quase a metade dos que expressaram alguma opinião situando o judiciário brasileiro como regular no que diz respeito a esse atributo. Esses resultados sugerem que o desempenho do judiciário brasileiro poderia ser significativamente melhorado caso os procedimentos fossem alterados de maneira a acelerar a velocidade com que os casos são julgados.

Tabela 2.1: Avaliação dos atributos do judiciário brasileiro

\begin{tabular}{|l|c|c|c|c|c|c|}
\hline \multirow{2}{*}{} & \multicolumn{2}{|c|}{ Agilidade } & \multicolumn{2}{c|}{ Imparcialidade } & \multicolumn{2}{c|}{ Custos } \\
\cline { 2 - 7 } & Frequência & $\%$ & Frequência & $\%$ & Frequência & $\%$ \\
\hline Ótimo & 7 & 1,2 & 9 & 1,5 & 7 & 1,2 \\
Bom & 0 & 0,0 & 148 & 24,6 & 83 & 13,8 \\
Regular & 48 & 8,1 & 267 & 44,4 & 232 & 38,5 \\
Ruim & 540 & 90,08 & 132 & 21,9 & 158 & 26,2 \\
Péssimo & 0 & 0,0 & 22 & 3,7 & 92 & 15,3 \\
Sem Opinião & 0 & 0,0 & 24 & 4,0 & 30 & 5,0 \\
Total & 595 & 100,0 & 602 & 100,0 & 602 & 100,0 \\
\hline
\end{tabular}

A segunda questão pedia aos entrevistados para avaliarem o desempenho das diversas instituições do sistema judiciário brasileiro - definido aqui de forma a incorporar o Ministério Público e os Cartórios Judiciais. Utilizando a dominância estocástica como critério de comparação, temos, numa hierarquia do mais até o menos eficiente, o Supremo Tribunal Federal, o Ministério Público e a Justiça Federal (Tabela 2.2). Esta última, contudo, é considerada como ruim ou péssima por mais da metade dos entrevistados que expressaram alguma opinião. A Justiça Comum Estadual e os Cartórios Judiciais são avaliados de forma ainda mais negativa, sobretudo os últimos. Talvez o resultado mais intrigante refira-se aos $11,6 \%$ dos respondentes que classificaram a Justiça do Trabalho como ótima, considerando-se que se trata de uma pesquisa com empresas, que, em geral, tendem a criticar o desempenho desse ramo da justiça. Uma explicação para esse resultado até certo ponto inesperado aparece na análise da questão seguinte. 
Tabela 2.2: Avaliação dos diferentes ramos do Judiciário

\begin{tabular}{|c|c|c|c|c|c|c|c|c|}
\hline & & Ótimo & Bom & Regular & Ruim & Péssimo & Sem opinião & Total \\
\hline Justiça do & Freq. & 69 & 0 & 162 & 362 & 0 & 0 & 593 \\
\hline Trabalho & $\%$ & 11,6 & 0,0 & 27,3 & 61,0 & 0,0 & 0,0 & 100,0 \\
\hline Justiça & Freq. & 5 & 73 & 201 & 190 & 104 & 29 & \\
\hline Federal & $\%$ & 0,8 & 12,1 & 33,4 & 31,6 & 17,3 & 4,8 & 100,0 \\
\hline Justiça & Freq. & 1 & 53 & 197 & 208 & 115 & 28 & \\
\hline $\begin{array}{l}\text { Comum } \\
\text { Estadual }\end{array}$ & $\%$ & 0,2 & 8,8 & 32,7 & 34,6 & 19,1 & 4,7 & 100,0 \\
\hline Supremo & Freq. & 9 & 141 & 205 & 110 & 54 & 83 & \\
\hline $\begin{array}{l}\text { Tribunal } \\
\text { Federal }\end{array}$ & $\%$ & 1,5 & 23,4 & 34,1 & 18,3 & 9,0 & 13,8 & 100,0 \\
\hline Ministéri & Freq. & 5 & 75 & 227 & 151 & 75 & 69 & \\
\hline o Público & $\%$ & 0,8 & 12,5 & 37,7 & 25,1 & 12,5 & 11,5 & 100,0 \\
\hline Cartórios & Freq. & 2 & 40 & 165 & 196 & 147 & 52 & \\
\hline Judiciais & $\%$ & 0,3 & 6,6 & 27,4 & 32,6 & 24,4 & 8,6 & 100,0 \\
\hline
\end{tabular}

A terceira questão foi formulada da seguinte maneira:

Afirma-se que a morosidade do judiciário às vezes prejudica e outras vezes beneficia as empresas que propõem ações na justiça. Em seu ramo de atividade, o Sr. diria que, na maioria dos casos, a morosidade é prejudicial, benéfica ou neutra, do ponto de vista das empresas?

A Tabela 2.3 mostra que somente $44,2 \%$ dos entrevistados acham que a lentidão da Justiça do Trabalho é algo prejudicial. Para a maioria, tal característica é neutra ou mesmo benéfica. Como discutido em Camargo (1996), muitas firmas se valem da morosidade dos tribunais do trabalho para pressionarem os trabalhadores a aceitarem um arranjo negociado em disputas financeiras. Embora menos conspícuo, um resultado similar foi observado nas questões relacionadas a tributos, direitos do consumidor e meio-ambiente. No Brasil, não é incomum as empresas recorrerem aos tribunais, questionando a legalidade de impostos, com o objetivo de adiar o seu pagamento. ${ }^{1}$ Somente no caso dos contratos (direito comercial), a morosidade judiciária não é percebida como benéfica por uma proporção significativa dos entrevistados.

\footnotetext{
${ }^{1}$ É interessante notar que a proporção dos que consideram a lentidão prejudicial em causas tributárias diminui conforme se passa da esfera federal para a estadual e desta para a municipal.
}

A quarta questão dizia respeito aos custos que as empresas se veem obrigadas a arcar quando levam uma disputa para os tribunais. Lê-se da seguinte maneira:

Afirma-se também que as empresas às vezes não propõem ações devido ao alto custo do acesso à justiça. Considerando a sua experiência e a de outras empresas no mesmo ramo de atividade, como o Sr. avalia os custos (diretos e indiretos) do acesso ao judiciário?

Os resultados, tabulados abaixo, indicam que os custos não consistem em impedimento maior para as firmas que desejam iniciar um litígio. Embora uma grande proporção dos entrevistados tenha afirmado que os custos são altos - opinião consistente com os resultados na Tabela 2.1 -, somente $10 \%$ indicaram que esse fato poderia dificultar o acesso ao judiciário (Tabela 2.4).

Tabela 2.3: Efeito da morosidade do judiciário: Prejudicial ou benéfico?

\begin{tabular}{|l|c|c|c|c|c|c|}
\hline \multicolumn{2}{|c|}{ Referência dos casos } & Benéfico & Prejudicial & Neutro & Sem opinião & Total \\
\hline \multirow{2}{*}{ Questões trabalhistas } & Freq. & 141 & 266 & 177 & 18 & 602 \\
& $\%$ & 23,4 & 44,2 & 29,4 & 3,0 & 100,0 \\
Tributos Federais & Freq. & 84 & 432 & 59 & 27 & 602 \\
Tributos Estaduais & $\%$ & 14,0 & 71,8 & 9,8 & 4,5 & 100,0 \\
& Freq. & 84 & 412 & 75 & 31 & 602 \\
Tributos Municipais & $\%$ & 14,0 & 68,4 & 12,5 & 5,1 & 100,0 \\
& Freq. & 64 & 345 & 97 & 96 & 602 \\
Contratos comerciais economicos & $\%$ & 10,6 & 57,3 & 16,1 & 15,9 & 100,0 \\
& Freq. & 20 & 432 & 97 & 53 & 602 \\
Direitos do consumidor & $\%$ & 3,3 & 71,8 & 16,1 & 8,8 & 100,0 \\
& Freq. & 66 & 314 & 130 & 92 & 602 \\
Meio ambiente & $\%$ & 11,0 & 52,2 & 21,6 & 15,3 & 100,0 \\
& Freq. & 64 & 295 & 120 & 123 & 602 \\
& $\%$ & 10,6 & 49,0 & 19,9 & 20,4 & 100,0 \\
\hline
\end{tabular}

Tabela 2.4: Custos da utilização do judiciário

\begin{tabular}{|l|c|c|}
\hline & \multicolumn{2}{|c|}{ Custos } \\
\hline & Frequência & $\%$ \\
Muito altos, a ponto de impedir o acesso & 61 & 10,1 \\
Altos, mas não a ponto de impedir o acesso & 344 & 57,1 \\
Razoáveis & 172 & 28,6 \\
Baixos & 6 & 1,0 \\
Muito Baixos, a ponto de facilitar excessivamente o acesso & 10 & 1,7 \\
Não sabe & 9 & 1,5 \\
Total & 602 & 100,0 \\
\hline
\end{tabular}


A conclusão de que as empresas encaram os custos de acesso ao judiciário como um problema de importância apenas moderada é corroborada pelas respostas à nona questão, que se referia ao benefício líquido do litígio, perguntando:

Nos processos em que sua empresa foi autora, e considerando todos os custos e benefícios econômicos, o Sr. diria que os benefícios superaram os custos, os custos superaram os benefícios, ou benefícios e custos foram aproximadamente iguais? ${ }^{2}$

Como exposto na Tabela 2.5, a vasta maioria das firmas respondeu ter se beneficiado, em termos líquidos, ao recorrer aos tribunais, e somente $11 \%$ afirmaram que os custos superaram os benefícios.

Tabela 2.5: Benefícios e custos da utilização do judiciário

\begin{tabular}{|l|c|c|}
\hline & Frequência & $\%$ \\
\hline Benefícios superaram custos & 345 & 59,4 \\
Custos superaram benefícios & 64 & 11,0 \\
Benefícios e custos foram aproximadamente iguais & 72 & 12,4 \\
Não sabe & 100 & 17,2 \\
Total & 581 & 100,0 \\
\hline
\end{tabular}

As questões de 5 a 8 focalizaram a natureza do envolvimento em litígios por parte dos entrevistados. As questões indagaram: (i) o número de casos em que a companhia agiu como autora ou como ré; (ii) a área do judiciário no qual o caso foi julgado; (iii) o número de casos decididos a favor ou contra a empresa e a proporção de casos resolvidos por acordo entre as partes; e (iv) a duração média dos julgamentos.

A grande maioria das empresas respondeu ter proposto e ter sido acionada em ações judiciais (86\% nos dois casos). Conforme apresentado na Tabela 2.6, o maior número de litígios em que as empresas se vêm envolvidas concentra-se na área trabalhista, e neste caso elas são normalmente rés nos processos. Em ações na área tributária, as empresas são em geral autoras, exceto pela esfera municipal, na qual a situação de ré é mais comum. ${ }^{3}$ A situação de autora também é predominante nas causas comerciais e naquelas

${ }^{2}$ Somente empresas que constituíram uma das partes num caso judicial desde 1986 responderam às questões de 6 a 11 .

${ }^{3} \mathrm{O}$ que ajuda a entender porque neste caso uma menor proporção de empresas considera a lentidão da justiça prejudicial. envolvendo propriedade industrial, enquanto nas áreas de direito do consumidor e meio ambiente as empresas são em geral rés no processo.

Na Tabela 2.7 observa-se que a solução por acordo é comum em litígios em várias áreas do direito, sendo exceções aqueles localizados na área tributária em âmbito federal e os que envolvem propriedade intelectual, marcas e patentes, nos quais em geral a resolução se dá por decisão judicial.

Tabela 2.6: Forma de resolução do litígio em ações concluídas por área (número de casos)

\begin{tabular}{|l|c|c|c|}
\hline \multirow{2}{*}{\multicolumn{1}{|c|}{ Áreas }} & \multicolumn{2}{|c|}{ Decisão } & Por \\
\cline { 2 - 4 } & Favorável à empresa & Contrária à empresa & Acordo \\
\hline Trabalhista & 10825 & 13533 & 18309 \\
Tributária Esfera Federal & 1455 & 580 & 25 \\
Tributária Esfera Estadual & 551 & 248 & 211 \\
Tributária Esfera Municipal & 93 & 33 & 34 \\
Comercial Econômica em Geral & 3069 & 530 & 1132 \\
Propriedade Industrial Marcas e Patentes & 76 & 16 & 3 \\
Direitos do Consumidor & 113 & 101 & 139 \\
Meio Ambiente & 35 & 10 & 7 \\
\hline
\end{tabular}

Meio Ambiente

Tabela 2.7: Ações em que as empresas foram parte nos 10 anos anteriores à pesquisa, por área

\begin{tabular}{|c|c|c|c|c|c|c|}
\hline \multirow{2}{*}{ Áreas } & \multicolumn{2}{|c|}{ Como autora } & \multicolumn{2}{|c|}{ Como ré } & \multicolumn{2}{|c|}{ Total } \\
\hline & Concluídas & Em andamento & Concluídas & Em andamento & Concluídas & Em andamento \\
\hline Trabalhista & 957 & 947 & 66865 & 38888 & 67822 & 39835 \\
\hline $\begin{array}{l}\text { Tributária } \\
\text { Esfera Federal }\end{array}$ & 2354 & 4071 & 532 & 853 & 2886 & 4924 \\
\hline $\begin{array}{l}\text { Tributária } \\
\text { Esfera Estadual }\end{array}$ & 553 & 1138 & 360 & 683 & 913 & 1821 \\
\hline $\begin{array}{l}\text { Tributária } \\
\text { Esfera } \\
\text { Municipal }\end{array}$ & 85 & 193 & 100 & 499 & 185 & 692 \\
\hline $\begin{array}{l}\text { Comercial } \\
\text { Econômica em } \\
\text { Geral }\end{array}$ & 6383 & 4688 & 1040 & 2056 & 7423 & 6744 \\
\hline $\begin{array}{l}\text { Propriedade } \\
\text { Industrial } \\
\text { Marcas e } \\
\text { Patentes }\end{array}$ & 87 & 112 & 11 & 12 & 98 & 124 \\
\hline $\begin{array}{l}\text { Direitos do } \\
\text { Consumidor }\end{array}$ & 26 & 11 & 441 & 479 & 467 & 490 \\
\hline Meio Ambiente & 7 & 5 & 31 & 37 & 38 & 42 \\
\hline
\end{tabular}


Na Tabela 2.8 apresentamos a distribuição da duração aproximada em meses entre a proposição e a decisão final, do total de ações já concluídas e nas quais não houve acordo, nas ações iniciadas nos ramos trabalhista, federal e estadual do judiciário nos dez anos anteriores à pesquisa. Dois resultados são dignos de nota. Primeiro, que é mais comum as firmas se verem envolvidas com a Justiça do Trabalho do que com as Justiças Federal e Estadual. Segundo, que as disputas resolvidas por decisão judicial levaram em média 31 meses na Justiça do Trabalho, 38 na Justiça Estadual e 46 na Justiça Federal. ${ }^{4}$

Tabela 2.8: Duração aproximada das decisões

judiciais por ramo do judiciário (em meses)

\begin{tabular}{|c|c|c|c|c|c|c|}
\hline \multirow{2}{*}{$\begin{array}{c}\text { Duração das } \\
\text { ações } \\
\text { (em meses) }\end{array}$} & \multicolumn{2}{|c|}{ Trabalhista } & \multicolumn{2}{|c|}{ Federal } & \multicolumn{2}{|c|}{ Estadual } \\
\hline & $\begin{array}{l}\text { Frequência } \\
\left(\mathrm{n}^{\circ} \text { empresas) }\right.\end{array}$ & $\%$ & $\begin{array}{l}\text { Frequência } \\
\text { (no empresas) }\end{array}$ & $\%$ & $\begin{array}{l}\text { Frequência } \\
\left(\mathrm{n}^{\circ} \text { empresas) }\right.\end{array}$ & $\%$ \\
\hline$£ 6$ & 42 & 9,2 & 5 & 1,5 & 6 & 2,2 \\
\hline 6 a 12 & 54 & 11,8 & 16 & 4,7 & 24 & 9,0 \\
\hline 12 a 24 & 128 & 27,9 & 46 & 13,6 & 60 & 22,4 \\
\hline 24 a 36 & 110 & 24,0 & 85 & 25,1 & 65 & 24,3 \\
\hline 36 a 48 & 65 & 14,2 & 67 & 19,8 & 48 & 17,9 \\
\hline 48 a 60 & 39 & 8,5 & 67 & 19,8 & 48 & 17,9 \\
\hline 60 a 96 & 17 & 3,7 & 45 & 13,3 & 14 & 5,2 \\
\hline$>96$ & 4 & 0,9 & 7 & 2,1 & 3 & 1,1 \\
\hline Total & 459 & 100,0 & 338 & 100,0 & 268 & 100,0 \\
\hline Média & \multicolumn{2}{|c|}{31 meses } & \multicolumn{2}{|c|}{46 meses } & \multicolumn{2}{|c|}{38 meses } \\
\hline
\end{tabular}

A décima questão buscou descobrir se as instituições públicas retaliavam as companhias que acionavam o setor público na justiça. A questão foi formulada da seguinte maneira:

Às vezes ocorre que uma empresa, ao ser parte em um processo, sofre constrangimentos diretos ou indiretos. Nos processos em que sua empresa foi parte contra órgãos públicos, empresas estatais ou mistas, ou empresas privadas, ela alguma vez sofreu constrangimentos sérios a ponto de prejudicar suas atividades normais?

A distribuição das respostas, apresentada na Tabela 2.9, indica que a retaliação é pouco comum quando o litígio envolve empresas públicas. Ela também não é frequente quando o litígio é contra outros órgãos públicos,

\footnotetext{
${ }^{4}$ A comparação direta entre os ramos do judiciário deve ter o cuidado de levar em conta que
} a complexidade dos casos julgados provavelmente não é homogênea. ainda que nesse caso a frequência com que se observa essa prática seja praticamente o dobro daquela registrada no caso das empresas públicas.

A décima - primeira questão focalizou de maneira mais direta o impacto do desempenho judicial sobre a atividade econômica, indagando sobre se alguma vez a empresa tivera suas decisões de investimento ou produção alteradas por força de decisão judicial ou se tivera de imobilizar capital durante a pendência de um litígio. A questão se lê da seguinte maneira:

Em tese, empresas podem ser afetadas de maneira negativa por ato ou omissão da justiça. Nos últimos dez anos, desde primeiro de janeiro de 1986, a sua empresa foi alguma vez afetada de maneira negativa por decisão da justiça? Por exemplo:[ver Tabela 2.9].

Os resultados da Tabela 2.10 sugerem que as firmas percebem a imobilização do capital financeiro (e possivelmente a perda de retorno implícita) como a forma mais recorrente pela qual o judiciário impacta suas atividades. Vale a pena notar, ainda, que mais de um terço daqueles que expressaram alguma opinião indicaram ter projetos de investimento que, de alguma maneira, foram afetados por uma determinação judicial. Uma proporção menor, mas ainda assim significativa de empresas, indicou que suas atividades foram afetadas por decisões judiciais.

A décima - segunda questão indagou se a companhia mantinha seu próprio departamento jurídico e, se sim, desde quando. Cerca de metade das empresas entrevistadas respondeu afirmativamente e, entre essas, 84,3\% indicaram que têm seu departamento jurídico há mais de cinco anos. A questão 13 indagou se a companhia do entrevistado "regularmente recorria a serviços externos de advocacia consultiva ou litigiosa". A Tabela 2.11 indica que esta prática e comum no meio empresarial, mesmo no caso daquelas firmas que mantêm seu próprio departamento jurídico.

Tabela 2.9: Retaliação de instituições públicas

\begin{tabular}{|l|c|c|c|c|}
\hline \multirow{2}{*}{} & \multicolumn{2}{|c|}{$\begin{array}{c}\text { Processos contra } \\
\text { órgãos públicos }\end{array}$} & \multicolumn{2}{c|}{$\begin{array}{c}\text { Processos contra empresas } \\
\text { públicas ou de economia mista }\end{array}$} \\
\cline { 2 - 5 } & Freq. & $\%$ & Freq. & $\%$ \\
\hline Sofreram constrangimentos muitas vezes & 47 & 8,1 & 25 & 4,3 \\
Sofreram constrangimentos algumas & 172 & 29,6 & 88 & 15,1 \\
vezes, mas foram fatos isolados & 281 & 48,4 & 253 & 43,5 \\
Nunca sofreram constrangimentos & 81 & 13,9 & 215 & 37,0 \\
Não sabe / Sem opinião & 581 & 100,0 & 581 & 100,0 \\
Total & \multicolumn{4}{|r}{} \\
\hline
\end{tabular}


Tabela 2.10: Efeitos negativos de decisões judiciais

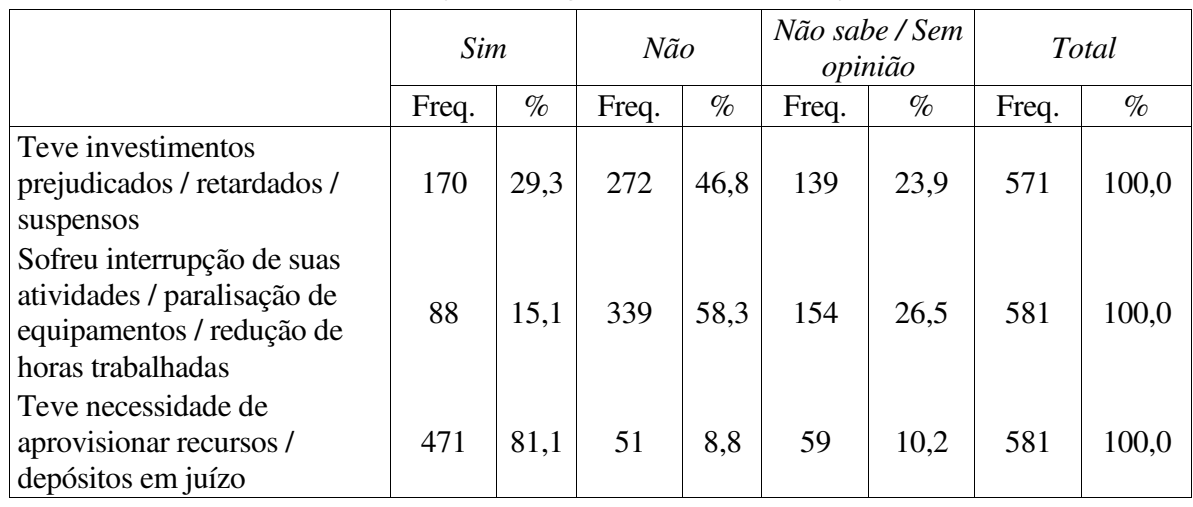

Tabela 2.11: Departamento jurídico próprio

\begin{tabular}{|l|c|c|}
\hline & Frequência & $\%$ \\
\hline Sim, mantém departamento jurídico próprio há mais de 5 anos & 243 & 40,4 \\
Sim, mantém há menos de 5 anos & 45 & 7,5 \\
Não mantém departamento jurídico próprio & 298 & 49,5 \\
Não respondeu & 16 & 2,7 \\
Total & 602 & 100,0 \\
\hline
\end{tabular}

Tabela 2.12: Serviços externos de advocacia

\begin{tabular}{|c|c|c|c|c|c|c|c|c|}
\hline $\begin{array}{l}\text { Sua companhia recorre } \\
\text { regularmente a serviços }\end{array}$ & \multicolumn{2}{|c|}{ Sim } & \multicolumn{2}{|c|}{ Não } & \multicolumn{2}{|c|}{ Não respondeu } & \multicolumn{2}{|c|}{ Total } \\
\hline $\begin{array}{l}\text { Consultiva } \\
\text { Litigiosa }\end{array}$ & $\begin{array}{c}\text { Freq. } \\
492 \\
431\end{array}$ & $\begin{array}{c}\% \\
81,7 \\
71,6\end{array}$ & $\begin{array}{c}\text { Freq. } \\
82 \\
108\end{array}$ & $\begin{array}{c}\% \% \\
13,6 \\
17,9\end{array}$ & $\begin{array}{c}\text { Freq. } \\
28 \\
63\end{array}$ & $\begin{array}{c}\% \\
4,7 \\
10,5\end{array}$ & $\begin{array}{c}\text { Freq. } \\
602 \\
602\end{array}$ & $\begin{array}{c}\% \\
100,0 \\
100,0\end{array}$ \\
\hline
\end{tabular}

As questões 14 a 17 referiram-se ao uso alternativo de mecanismos de resolução de disputas, como a negociação direta e a arbitragem. As questões se leem como indicado em cada uma das tabelas seguintes. Na Tabela 2.13, vemos que dois terços dos entrevistados afirmaram que cláusulas de arbitragem ou de negociação não estavam contempladas em nenhum dos contratos em que suas respectivas firmas tomaram parte. No entanto, $30 \%$ reconheceram a existência de tais cláusulas em pelo menos alguns dos contratos. Isto parece indicar que, muito embora a arbitragem e a mediação não se constituam em práticas disseminadas entre a comunidade empresarial no Brasil, também não são inteiramente estranhas às firmas.
Tabela 2.13: Contratos prevendo recurso à mediação e à arbitragem Discute-se hoje em dia a mediação e a arbitragem como formas alternativas de resolução de conflitos na área comercial, sem passar pelo judiciário. Nos contratos firmados por sua empresa nos últimos cinco anos, tem sido inserida cláusula específica prevendo a solução de possíveis litígios através da mediação e/ou da arbitragem?

\begin{tabular}{|l|c|c|}
\hline & Freq. & $\%$ \\
\hline Sim, na maioria dos contratos & 43 & 7,1 \\
Em alguns casos/raramente & 138 & 22,9 \\
Não/Nunca ocorreu & 399 & 66,3 \\
Não sabe & 22 & 3,7 \\
Total & 602 & 100,0 \\
\hline
\end{tabular}

As Tabelas 2.14 e 2.15 indicam que a arbitragem e a mediação são meios um pouco mais comuns de se tentar resolver disputas antes do recurso aos tribunais em casos trabalhistas e, em menor grau, comerciais. Em relação aos primeiros, 54,1\% dos entrevistados afirmaram que sempre, ou ao menos frequentemente, recorriam à mediação em negociações salariais antes de irem aos tribunais. Ainda assim, quase um terço das empresas respondeu que nunca recorria a essas alternativas. Em casos comerciais, 40,7\% responderam que era comum tentarem resolver as disputas por meio da arbitragem ou da mediação antes do recurso ao judiciário. Mas 43,2\% dos entrevistados disseram que nunca seguiam esse caminho.

Tabela 2.14: Frequência dos recursos à mediação e à arbitragem- área comercial Em questões comerciais, com que frequência sua empresa tem buscado resolver conflitos através da mediação e/ou arbitragem, antes de recorrer ao judiciário?

\begin{tabular}{|l|c|c|}
\hline & Freq. & $\%$ \\
\cline { 2 - 3 } Sempre & 145 & 24,1 \\
Frequentemente & 100 & 16,6 \\
Raramente & 86 & 14,3 \\
Nunca & 260 & 43,2 \\
Não Sabe & 11 & 1,8 \\
Total & 602 & 100,0 \\
\hline
\end{tabular}

Tabela 2.15: Frequência dos recursos à mediação e à arbitragem-área trabalhista $\mathrm{Na}$ área trabalhista, com que frequência a sua empresa recorre à mediação nas negociações salariais, antes da instauração do dissídio na Justiça do Trabalho?

\begin{tabular}{l|c|c} 
& Freq. & $\%$ \\
\cline { 2 - 3 } Sempre & 227 & 37,7 \\
Frequentemente & 99 & 16,4 \\
Raramente & 72 & 12,0 \\
Nunca & 188 & 31,2 \\
Não Sabe & 16 & 2,7 \\
Total & 602 & 100,0 \\
\hline
\end{tabular}


Em disputas com trabalhadores, uma grande parcela $(50,5 \%)$ dos casos é resolvida por acordo ou descontinuada depois de o caso haver atravessado a primeira instância do sistema judicial (Tabela 2.16). Mas há uma também elevada proporção de casos trabalhistas que raramente ou nunca $(46,2 \%)$ são encerrados antes de chegarem à segunda instância.

\section{Tabela 2.16: Frequência de acordo ou encerramento} após primeira instância- área trabalhista

\begin{tabular}{|l|c|c|}
\hline Ainda na área trabalhista, com que frequência sua empresa chegou a acordo ou & Freq. & $\%$ \\
encerrou ação após a primeira instância? & 53 & 8,8 \\
\hline Sempre & 251 & 41,7 \\
Frequentemente & 216 & 35,9 \\
Raramente & 62 & 10,3 \\
Nunca & 20 & 3,3 \\
Não Sabe & 602 & 100,0 \\
Total
\end{tabular}

Na Tabela 2.17, verificamos que $77,2 \%$ dos entrevistados são favoráveis ao fim do poder normativo da Justiça do Trabalho e de sua prerrogativa de regular aumentos salariais e outras questões econômicas que dizem respeito às relações capital-trabalho. É interessante observar, porém, que além de a defesa dessa proposta não contar com a unanimidade da classe empresarial, quase a metade dos que a apoiam o faz com ressalvas.

Tabela 2.17: Ponto de vista sobre o poder normativo da justiça do trabalho Ainda sobre a área trabalhista, tem-se proposto a eliminação do poder normativo da Justiça do Trabalho para julgar reajustes salariais e outros conflitos econômicos entre empregados e empregadores. O Sr. é a favor ou contra essa proposta?

\begin{tabular}{|l|c|c|}
\hline & Freq. & $\%$ \\
\cline { 2 - 3 } Totalmente a favor & 251 & 41,7 \\
A favor com ressalvas & 214 & 35,5 \\
Indiferente & 21 & 3,5 \\
Contra com ressalvas & 50 & 8,3 \\
Totalmente contra & 37 & 6,1 \\
Sem opinião & 29 & 4,8 \\
Total & 602 & 100,0 \\
\hline
\end{tabular}

As questões 19 a 21 fizeram referência à experiência do entrevistado com os sistemas judiciais de outros países e à sua. avaliação do judiciário brasileiro em comparação aos deles. As questões estão indicadas nas tabelas. Na Tabela 2.18, podemos ver que somente um terço das empresas se situa em áreas de negócios que requerem conhecimento sobre o sistema judicial de outros países.
Tabela 2.18: Experiência com o judiciário de outros países

\begin{tabular}{|l|c|c|}
\hline As atividades de sua empresa requerem conhecimento do sistema e dos & Freq. & $\%$ \\
procedimentos judiciais de outros países? & 14 & 2,3 \\
\hline Sim, muito & 192 & 31,9 \\
Sim, até certo ponto & 381 & 63,3 \\
Não & 15 & 2,5 \\
Sem Opinião & 602 & 100,0 \\
\hline
\end{tabular}

Tabela 2.19: Países cujos judiciários são conhecidos pelos entrevistados

Indique, por favor, em relação a quais dos países listados abaixo sua empresa precisa ter conhecimento do sistema e dos procedimentos judiciais

\begin{tabular}{|c|c|c|c|c|c|c|}
\hline \multirow{3}{*}{$\begin{array}{l}\text { Estados } \\
\text { Unidos }\end{array}$} & \multirow{3}{*}{$\begin{array}{c}\text { Freq. } \\
\%\end{array}$} & $\begin{array}{c}\text { Muito } \\
\text { conhecimento }\end{array}$ & $\begin{array}{c}\text { Algum } \\
\text { conhecimento }\end{array}$ & $\begin{array}{c}\text { Nenhum } \\
\text { conhecimento }\end{array}$ & $\begin{array}{c}\text { Sem } \\
\text { Opinião }\end{array}$ & Total \\
\hline & & 28 & 133 & 5 & 40 & 206 \\
\hline & & 13,6 & 64,6 & 2,4 & 19,4 & 100,0 \\
\hline \multirow{2}{*}{ Alemanha } & Freq. & 7 & 58 & 31 & 100 & 206 \\
\hline & $\%$ & 3,4 & 28,2 & 15,0 & 48,5 & 100,0 \\
\hline \multirow{2}{*}{ Itália } & Freq. & 8 & 45 & 34 & 119 & 206 \\
\hline & $\%$ & 3,9 & 21,8 & 16,5 & 57,8 & 100,0 \\
\hline \multirow{2}{*}{ Portugal } & Freq. & 5 & 31 & 41 & 129 & 206 \\
\hline & $\%$ & 2,4 & 15,0 & 19,9 & 62,6 & 100,0 \\
\hline \multirow{2}{*}{ Japão } & Freq. & 6 & 34 & 37 & 129 & 206 \\
\hline & $\%$ & 2,9 & 16,5 & 18,0 & 62,6 & 100,0 \\
\hline \multirow{2}{*}{ China } & Freq. & 2 & 28 & 37 & 139 & 206 \\
\hline & $\%$ & 1,0 & 13,6 & 18,0 & 67,5 & 100,0 \\
\hline \multirow{2}{*}{ Argentina } & Freq. & 38 & 96 & 7 & 65 & 206 \\
\hline & $\%$ & 18,4 & 46,6 & 3,4 & 31,6 & 100,0 \\
\hline
\end{tabular}

Correspondendo a 206 firmas, esse um terço parece concentrar seus negócios nos Estados Unidos e, em menor medida, na Argentina (Tabela 2.19). Mesmo no caso desses dois países, e de forma muito mais significativa no caso de outros, o conhecimento que as firmas dispõem sobre o sistema judicial parece bastante rudimentar. Basta notar que, das 602 firmas entrevistadas, somente 28 (4,7 por cento) declararam necessitar conhecer bem o sistema judicial do mais importante parceiro comercial do Brasil. Faremos uma discussão mais aprofundada sobre esta questão no quarto capítulo, onde a experiência dos empresários brasileiros com negócios no estrangeiro será analisada em detalhe. 
Tabela 2.20: Avaliação comparativa da qualidade do judiciário brasileiro Tomando como referência a experiência de sua empresa e de outras do mesmo ramo, como o Sr. compara o Judiciário brasileiro com o dos países listados abaixo $\}$

\begin{tabular}{|c|c|c|c|c|c|c|c|c|}
\hline \multirow{3}{*}{$\begin{array}{l}\text { Estados } \\
\text { Unidos }\end{array}$} & \multirow[b]{2}{*}{ Freq. } & $\begin{array}{l}\text { Muito } \\
\text { melhor }\end{array}$ & Melhor & Igual & Pior & $\begin{array}{l}\text { Muito } \\
\text { pior }\end{array}$ & $\begin{array}{c}\text { Sem } \\
\text { opinião }\end{array}$ & Total \\
\hline & & 14 & 28 & 7 & 44 & 39 & 74 & 206 \\
\hline & $\%$ & 6,8 & 13,6 & 3,4 & 21,4 & 18,9 & 35,9 & 100,0 \\
\hline \multirow{2}{*}{ Alemanha } & Freq. & 9 & 9 & 4 & 23 & 18 & 143 & 206 \\
\hline & $\%$ & 4,4 & 4,4 & 1,9 & 11,2 & 8,7 & 69,4 & 100,0 \\
\hline \multirow{2}{*}{ Itália } & Freq. & 3 & 7 & 19 & 25 & 5 & 147 & 206 \\
\hline & $\%$ & 1,5 & 3,4 & 9,2 & 12,1 & 2,4 & 71,4 & 100,0 \\
\hline \multirow{2}{*}{ Portugal } & Freq. & 0 & 3 & 17 & 12 & 3 & 171 & 206 \\
\hline & $\%$ & 0,0 & 1,5 & 8,3 & 5,8 & 1,5 & 83,0 & 100,0 \\
\hline \multirow{2}{*}{ Japão } & Freq. & 4 & 4 & 2 & 13 & 13 & 170 & 206 \\
\hline & $\%$ & 1,9 & 1,9 & 1,0 & 6,3 & 6,3 & 82,5 & 100,0 \\
\hline \multirow{2}{*}{ China } & Freq. & 1 & 7 & 2 & 6 & 1 & 189 & 206 \\
\hline & $\%$ & 0,5 & 3,4 & 1,0 & 2,9 & 0,5 & 91,7 & 100,0 \\
\hline \multirow{2}{*}{ Argentina } & Freq. & 0 & 20 & 43 & 18 & 2 & 123 & 206 \\
\hline & $\%$ & 0,0 & 9,7 & 20,9 & 8,7 & 1,0 & 59,7 & 100,0 \\
\hline
\end{tabular}

Empresários com experiência no mercado internacional não parecem ter uma posição especialmente crítica em relação ao sistema judicial brasileiro, constatação que, como se verá, é consistente com a análise apresentada no quarto capítulo. Na média, situam o judiciário brasileiro no mesmo nível daqueles da Argentina e China - ainda que o pequeno número de respostas sobre a justiça na China sugira cuidado com esta comparação -, e abaixo dos sistemas judiciais das democracias avançadas. Destes, os judiciários de Portugal, Japão e Itália, nesta ordem, são aqueles como menor vantagem em relação ao brasileiro. O judiciário da Alemanha e, em particular, o dos Estados Unidos surgem como aqueles com maior diferencial em relação ao brasileiro.

\section{O JUDICIÁRIO E A ECONOMIA:
EVIDÊNCIA EMPÍRICA PARA O CASO BRASILEIRO}

Armando Castelar Pinheiro

\subsection{INTRODUÇÃO}

T o primeiro capítulo (Impacto sobre o Crescimento: Uma Análise Conceitual), analisamos conceitualmente como o mau funcionamento da justiça gera custos econômicos que podem comprometer o crescimento e observamos que, a despeito de uma conscientização crescente em relação a esses custos, pouco se tem caminhado na direção de se estimar a sua magnitude. Ao lado disso, como assinalamos na seção 4 daquele capítulo, a maior parte das análises empíricas disponíveis apresenta duas importantes limitações. Por um lado, ao se basearem em regressões de cross-sections de países, seguem uma metodologia com limitações intrínsecas. Em particular, ela nada informa sobre os canais através dos quais sistemas judiciais e crescimento econômico interagem entre si. Por outro lado, a maioria dos estudos se vale de medidas pouco precisas da qualidade dos sistemas judiciais, impedindo uma estimação confiável da sua influência sobre o crescimento econômico. Concluímos aquele capítulo defendendo a ideia de que se poderia ganhar muito com a condução de estudos de países individuais, nos quais a qualidade do judiciário e os custos que ela impõe ou deixa de impor sobre o desempenho econômico poderiam ser medidos de forma direta. É como procedemos em nosso estudo sobre os custos econômicos do mau funcionamento do judiciário no Brasil, apresentado a seguir.

Este capítulo descreve a metodologia aplicada em nossa análise empírica e apresenta nossos principais resultados. Está estruturado em nove seções. A seção 2 descreve a metodologia utilizada e os principais problemas surgidos quando da sua implementação. A seção 3 apresenta os achados da pesquisa qualitativa conduzida como passo preparatório para a nossa segunda pesquisa com empresas. A seção 4 examina como os empresários entrevistados avaliam a qualidade do sistema judicial no Brasil, complementando a análise do segundo capítulo. A seção 5 investiga os mecanismos utilizados pelas empresas como alternativas aos tribunais. A seção 6 expõe a avaliação qualitativa das firmas sobre o impacto do mau 
funcionamento da justiça sobre a economia. A seção 7 verifica como as firmas reagiriam a uma melhora na eficiência do judiciário.

\subsection{Metodologia E DESENHO DA PESQUiSA}

Os resultados da análise empírica descrita neste capítulo foram extraídos de uma pesquisa conduzida junto a empresários sobre como eles avaliavam o desempenho do judiciário no Brasil e seus prováveis impactos sobre a produção, o investimento e o emprego, como resultado de uma melhoria desse desempenho. A pesquisa perguntava aos empresários:

1. Se consideravam que a justiça brasileira funcionava bem e como hierarquizavam os problemas decorrentes do mau desempenho do judiciário vis a vis outros problemas que afetam os negócios no Brasil.

2. Se sentiam que esse mau desempenho comprometia o funcionamento da economia em geral e de suas respectivas firmas em particular.

3. Quão importante consideravam se valer de mecanismos alternativos para a resolução de disputas e/ou para selecionar fornecedores e clientes de forma a evitar os tribunais.

4. Se achavam que, em seus respectivos setores de atividade, os problemas do judiciário impactavam variáveis como juros, investimento, etc.

5. Se a falta de confiança no bom desempenho do judiciário foi alguma vez a principal razão para suas firmas não terem seguido uma linha de ação que, de outra maneira, teria sido a mais apropriada, como a decisão de não investir ou de substituir mão - de- obra por equipamentos.

6. Se a firma mudaria suas práticas de negócio caso o sistema judicial funcionasse melhor, recorrendo, por exemplo, mais intensamente à terceirização ou investindo mais em outros estados.

7. Quanto a firma alteraria suas práticas de negócios nesse último caso.

Nós também solicitamos informações básicas sobre a firma - como o número de empregados, o valor das receitas e assim por diante - e a intensidade com que a firma tendia a se ver envolvida em litígios. $\mathrm{O}$ questionário foi formulado para ser respondido em entrevistas pessoais, pelo principal executivo das firmas ou por algum outro alto dirigente da empresa.
As questões referentes aos dados sobre lucros, número de casos levados aos tribunais etc., foram colocadas numa folha anexa, a ser encaminhada ao Idesp por fax ou correio. Tivemos por alvo firmas de porte médio e grande (mais de 50 empregados), porque entendemos que firmas pequenas têm uma experiência significativamente diferente com o judiciário (possivelmente pior, mas de qualquer maneira diferente). Inicialmente, uma amostra de firmas foi elaborada de acordo com os seguintes passos:

a. O tamanho da amostra foi fixado em 300 (tendo em vista as limitações orçamentárias). Para limitar os custos, já que planejamos entrevistas pessoais, também restringimos nossa amostra a firmas localizadas no estado de São Paulo.

b. O universo amostral consistia de uma relação de aproximadamente 3.000 firmas, compreendendo as maiores de cada setor, relação compilada pelo jornal de negócios Gazeta Mercantil (a lista completa incluía aproximadamente 8.000 firmas em todos os estados brasileiros).

c. Para selecionar as firmas, utilizamos um processo de dupla estratificação. Inicialmente, estimamos a participação de cada setor na economia, a partir de dados sobre produção/valor agregado, emprego e ativos. Agricultura e administração pública não foram incluídas. Fixamos então para cada setor um número de observações proporcional ao seu peso na economia.

d. As firmas em cada setor foram ordenadas por tamanho (receitas) e separadas em um número de estratos igual ao número de observações atribuída ao setor. Uma firma foi então selecionada aleatoriamente de cada estrato.

Enfrentamos diversos problemas referentes ao desenho e à aplicação do questionário, alguns dos quais são dignos de nota:

\section{Elaborar adequadamente as questões}

Quando iniciamos os pré-testes e grupos focais (ver adiante), nós frequentemente detectamos uma reação inicial bastante positiva dos empresários, que apontavam que o mau funcionamento do judiciário prejudicava seriamente o desempenho econômico. No entanto, eles não se mostravam capazes de explicar de que maneira isso ocorria. Aparentemente, as firmas encontram formas de passar ao largo do judiciário e, em muitos casos, não dispõem de um claro entendimento de como e se esses procedimentos afetam o seu desempenho. Como consequência, gastamos uma considerável parcela de nosso tempo formulando as questões 
de maneira que elas fossem capazes de extrair dos empresários o tipo de informação que procurávamos.

\section{O acesso aos tomadores de decisão}

Tivemos muita dificuldade em entrevistar a maioria das firmas em nossa amostra. Como resultado, abandonamos nossa primeira estratégia amostral e enviamos o questionário para um grande número de firmas não incluídas na amostra original. Nossa amostra final foi composta por todas as firmas que fomos capazes de entrevistar através de contatos pessoais ou via correio. Um ganho com essa alternativa foi o de passarmos a contar com respostas de empresas localizadas em quase todos os estados do Brasil, com exceção do Acre, Amapá, Rondônia, Roraima e Tocantins.

\section{Completando os questionários}

Frequentemente, os entrevistados não forneceram todas as informações demandadas sobre receitas, investimento, natureza da propriedade, etc. Por essa razão, foi necessário contatar de novo as firmas para preencher os campos em branco. Ainda assim, alguns questionários permaneceram parcialmente incompletos.

\subsection{GRUPOS FOCAIS}

Além de aplicarmos pré-testes para diferentes versões do questionário, conduzimos duas sessões de grupo com empresários para discutir os custos econômicos do mau desempenho da justiça. As discussões confirmaram algumas das nossas primeiras hipóteses e sugeriram, ao mesmo tempo, novos caminhos. Entre as conclusões confirmadas, as mais relevantes são:

1. O judiciário não afeta de maneira significativa a maior parte das atividades ou decisões de investimento das firmas. Pelo menos esta é a percepção dos seus dirigentes. Muito embora as companhias classifiquem o sistema judicial como precário, geralmente conseguem contorná-lo, mantendo o judiciário fora de suas "vidas". As firmas se valem de mecanismos alternativos, tanto externos como internos, como substitutos para o papel que o judiciário deveria desempenhar. Este fato foi perfeitamente ilustrado pela reação de um participante quando questionado se um judiciário mais eficiente daria maior proteção às companhias: "a proteção é a estrutura legal mantida pelas grandes empresas; as pequenas têm a proteção de suas associações de classe". Não é fato comum, portanto, as firmas recorrerem aos tribunais para obrigarem a execução dos contratos; usualmente, preferem estabelecer alguma solução negociada. Mesmo na área das relações trabalhistas, na qual a interação com o sistema judicial é mais frequente, muitos casos são resolvidos por acordo, sem que uma sentença judicial tenha alguma vez sido proferida.

2. A morosidade é tida como o principal defeito do judiciário.

3. Muitas vezes, essa morosidade beneficia as firmas. Este é particularmente o caso em disputas relativas a tributos, nas quais as firmas recorrem ao judiciário para atrasar o seu pagamento.

4. Como resultado da grande "elasticidade" dos tribunais na interpretação da lei, "é sempre possível obter-se uma liminar ou um adiamento".

5. Há grande heterogeneidade no interior do sistema judicial. Juízes dos Tribunais Federais recebem melhores salários, enquanto os Tribunais Estaduais enfrentam a falta de recursos. No entanto, os diferenciais salariais não refletem a qualidade dos juízes, que vem melhorando no passado recente: "os padrões éticos têm melhorado". Um dos participantes sugeriu que os tribunais poderiam se beneficiar de uma maior especialização.

As discussões também nos permitiram atentar para outros aspectos do problema, sendo que os mais importantes dentre eles foram:

a. Ao lado da lentidão, um outro problema do judiciário consiste num certo grau de tendenciosidade que marca suas decisões. Um caso notório é o viés em favor dos trabalhadores nas disputas trabalhistas, o qual no entanto aparentemente foi reduzido desde a estabilização dos preços. Muito tempo também se consumiu na discussão do viés dos juízes de certos estados em favor dos devedores. Tais problemas foram caracterizados como importantes o suficiente para influenciar o volume de negócios conduzido em certas jurisdições. De forma menos enfática, também se mencionou que certos tribunais apresentam um viés geográfico, ou seja, tendem a favorecer firmas locais e residentes. Muito embora um dos participantes tenha chegado a mencionar a corrupção como uma possível causa das decisões tendenciosas, essa não foi a visão predominante. Aparentemente, os tribunais são tendenciosos porque favorecem certas classes de litigantes (trabalhadores, devedores, residentes locais etc.). Nesse sentido, 
empresários do setor financeiro se mostraram mais preocupados com o tema do que representantes da indústria.

$b$. Um outro fato discutido nos encontros foi que o ajuste ao mau funcionamento da justiça normalmente ocorre pelo aumento de preços e menos frequentemente pelo racionamento das quantidades (por exemplo, os bancos continuam emprestando, mas cobram maiores spreads). Em lugar de abdicar do negócio devido ao risco adicional introduzido pelo judiciário, as firmas reagem aumentando a taxa de retorno requerida. Obviamente, o resultado final consistirá em um menor nível de atividade, mas o mecanismo de preço permite uma melhor alocação de recursos do que o racionamento da oferta. A esse respeito, um dos participantes observou que "o judiciário aumenta custos, mas não riscos", por isto, o impacto do aumento da eficiência do judiciário se faria sentir na redução de custos.

c. Um dos participantes assinalou que o judiciário afetava muito pouco a "vida" das firmas já que o legislativo e o executivo eram os verdadeiros causadores de problemas. $\mathrm{O}$ primeiro, em razão do grande número de interações que uma firma mantém com o Estado em matérias administrativas (autoridades tributárias, agências reguladoras, etc.). O segundo devido à instabilidade das leis.

d. A estrutura legal foi apontada como uma razão para a não utilização de mecanismos de resolução de conflitos, como a arbitragem, porque a lei não proíbe à parte perdedora de recorrer aos tribunais num momento posterior. Também foi mencionado o fato de as instituições públicas não se acharem autorizadas a propor ou aceitar a solução de conflitos fora dos tribunais.

$e$. Ainda no que se refere à arbitragem, alguns participantes mencionaram que, tomando por base a sua experiência no exterior, aprenderam que há países em que os árbitros não são imparciais quando uma das partes não pertence à sua respectiva jurisdição. Árbitros na Itália, por exemplo, mostravam-se tendenciosos quando as causas envolviam uma empresa de fora da União Europeia.

f. Um outro problema apontado refere-se ao fato de o judiciário não proteger adequadamente as firmas do Estado. Nesse sentido, agências públicas como o Banco Central dispõem de grande poder de retaliação, e, por isto, as firmas não levam certos casos aos tribunais, muito embora estejam convencidas de que são prejudicadas pela ação incorreta dessas agências. Ainda nessa linha, um participante observou que o aumento de processos na área tributária foi encorajado pela percepção de que a capacidade de retaliação das autoridades dessa área era pequena. g. Há também um problema referente à falta de aplicação de decisões judiciais contra o Estado. São necessários muitos anos para se receber indenizações do Estado.

h. A importância de um bom sistema judicial para o processo de privatização foi assinalada por um dos participantes. Observou- se que se a inflação retornar e o governo tentar manter constantes as tarifas, as regras acordadas no contrato de concessão poderiam não ser aplicadas pelos tribunais. Há o receio de que o judiciário venha a se alinhar com as autoridades reguladoras para favorecer a parte "mais fraca", nesse caso os consumidores dos serviços públicos.

$i$. Os participantes responsabilizaram a cultura pela morosidade do judiciário. Aqui, dois fatores estariam em ação. O primeiro seria o "rito processual", que torna a análise dos casos necessariamente morosa: "o judiciário não se acha equipado para processos rápidos". O Juizado de Pequenas Causas foi lembrado como caso exemplar. Nele, a simplicidade dos casos julgados contrasta com a complexidade dos procedimentos. $\mathrm{O}$ segundo fator estaria ainda mais relacionado à cultura, consistindo na acomodação à morosidade, consciente ou não, de advogados, juízes e outros operadores do direito. Um dos participantes salientou, por exemplo, que a morosidade era inerente ao judiciário. Mencionou-se também, no entanto, que os juízes lidam com uma carga pesada de casos e que trabalham muito.

j. A acomodação cultural à morosidade do judiciário também apareceu quando se discutiu o tema das empresas estrangeiras "para as quais a ineficiência do judiciário poderia ser um problema”. Essa observação apareceu na sequencia de um argumento segundo o qual a ineficiência do judiciário é um problema, mas "tem muito pouca influência e não irá alterar nada: não aparece como uma questão levada em conta na decisão de um investimento". Para uma empresa estrangeira, no entanto, ela pode se constituir em um elemento que acabe por desencorajar investimentos.

Embora a questão tenha sido levantada diversas vezes, os participantes insistiram que a qualidade precária do judiciário não afetava de forma significativa suas atividades ou decisões de investimento. Obviamente há exceções, mas a é na prática as firmas não se sentem substancialmente afetadas pelo mau funcionamento do judiciário. Um dos participantes notou, por exemplo, que "as companhias se estabelecem levando em conta a oferta 
de matérias primas, a infraestrutura e os incentivos fiscais que irão receber (...) a questão da eficiência judicial não é levada em conta, é marginal".

Em certo sentido, o simples fato de diversas firmas terem enviado advogados para os grupos focais, e não executivos operacionais, indica que elas não associam o mau funcionamento do judiciário com a atividade de seus negócios. Antes pelo contrário; assinalou-se que muitas firmas veem na ineficiência do judiciário algo que tende a beneficiá-las, "as companhias de maneira geral têm-se beneficiado, o cidadão comum é aquele que de fato arca com os custos". Nesse sentido, as firmas não somente aprenderam a como evitar o judiciário e a substituir os tribunais, mas também a explorar a ineficiência do sistema em seu próprio benefício. Mesmo nos casos trabalhistas, mencionou-se que as empresas, via de regra, optam por não pagar os encargos sociais, negociando adiante um valor menor no tribunal. Indo um passo à frente, a exploração da ineficiência judicial começou a ser interpretada como um elemento de competitividade: "a morosidade dos tribunais beneficia o sonegador (...) que acaba sendo um competidor injusto".

\subsection{A EFICIÊNCIA DO JUDICIÁRIO BRASILEIRO}

Passamos agora à análise das respostas das empresas às perguntas desta segunda pesquisa de campo. Nosso primeiro conjunto de questões procurou apreender como os empresários avaliam a qualidade do judiciário brasileiro. Este tema já havia sido coberto em nossa primeira pesquisa, mas foi outra vez incluído para "aquecer" os entrevistados. A primeira questão pediu aos entrevistados para que hierarquizassem diversos problemas frequentemente citados por empresários como os que mais afetam a sua competitividade. A segunda questão pediu para que avaliassem o desempenho do judiciário brasileiro no que diz respeito à agilidade, imparcialidade e custos. Nossas terceira e quarta questões buscaram examinar a percepção dos entrevistados em relação à maneira pela qual o funcionamento do sistema judicial, ou não, a economia e suas firmas.

\subsubsection{Avaliação da eficiência do judiciário}

Para avaliar o desempenho judicial no Brasil, pedimos aos empresários que situassem o judiciário em relação à agilidade, à imparcialidade e aos custos. As respostas mostram que a agilidade é percebida como o pior dos três problemas (média entre ruim e péssimo), seguido por custos altos (média entre ruim e regular). No que se refere à imparcialidade, o judiciário brasileiro é avaliado como regular. Ao lado disso, vale notar que a imparcialidade domina majoritariamente a variável agilidade, o que reafirma a percepção de que a morosidade é o pior dos três problemas. De maneira geral, este é exatamente o mesmo quadro obtido em nossa pesquisa anterior com as empresas (capítulo 2), reforçando, portanto, a conclusão de que se pode obter uma melhora significativa do judiciário brasileiro se o problema da morosidade for adequadamente equacionado.

Tabela 3.1: Desempenho do judiciário brasileiro

\begin{tabular}{|l|c|c|c|c|c|c|}
\hline Como o Sr, avalia o judiciário brasileiro em relação aos seguintes aspectos: \\
\hline \multirow{4}{*}{ Ótimo } & \multicolumn{2}{|c|}{ Agilidade } & \multicolumn{2}{c|}{ Imparcialidade } & \multicolumn{2}{c|}{ Custos } \\
\cline { 2 - 7 } Bom & Freq. & $\%$ & Freq. & $\%$ & Freq. & $\%$ \\
\cline { 2 - 7 } Regular & 0 & 0,0 & 8 & 2,9 & 3 & 1,1 \\
Ruim & 3 & 1,1 & 73 & 26,2 & 31 & 11,1 \\
Péssimo & 26 & 9,3 & 119 & 42,7 & 116 & 41,6 \\
Sem opinião & 77 & 27,6 & 52 & 18,6 & 70 & 25,1 \\
Total & 270 & 60,9 & 19 & 6,8 & 44 & 15,8 \\
& 3 & 1,1 & 8 & 2,9 & 15 & 5,4 \\
& 279 & 100,0 & 279 & 100,0 & 279 & 100,0 \\
\hline
\end{tabular}

\subsubsection{Contextualizando a ineficiência do judiciário}

A primeira pergunta do questionário tentou avaliar se o mau funcionamento do judiciário é percebido como um importante problema relativamente a outras dificuldades enfrentadas pelas empresas. Com este fim, pedimos aos entrevistados para ordenarem diferentes problemas frequentemente citados pelos empresários como aqueles mais importantes no Brasil (os valores vão de 1, para o mais grave, a 5, para o menos grave). A relação inclui: carga tributária elevada, infraestrutura física deficiente, mau funcionamento da Justiça, encargos sociais elevados, altos índices de criminalidade e mão de obra pouco qualificada. Dois modelos de questionário foram utilizados, com encargos sociais elevados como uma das alternativas em um dos modelos, e índices elevados de criminalidade no outro. ${ }^{1}$ A questão foi colocada da seguinte maneira:

${ }^{1}$ Cabe notar que introduzimos essa pergunta como a primeira do questionário para minimizar a influência de repetidas perguntas a respeito do judiciário sobre o julgamento dos entrevistados. 
As empresas que atuam no Brasil já estão conscientes da necessidade de se tornarem mais eficientes e competitivas, mas esbarram em uma série de problemas que afetam seus custos, operações e planos de investimento. A seu ver, quais dos cinco problemas indicados abaixo são mais graves, em termos de impacto negativo, para sua empresa?

Os resultados confirmam alguns resultados encontrados em outras pesquisas similares, em particular, que as empresas identificam na carga tributária elevada seu principal problema (Tabela 3.2). ${ }^{2}$ Elevados encargos sociais aparecem como o segundo mais importante problema. $\mathrm{O}$ mau funcionamento do judiciário vem em terceiro lugar, lado a lado com a falta de infraestrutura e levemente à frente da ausência de mão de obra qualificada. "Índices elevados de criminalidade" foram apontados como o menos importante dos problemas propostos na questão. Este ordenamento indica que o mau funcionamento da justiça é percebido como um problema, mas não como a grande prioridade na agenda de reformas. No entanto, o fato dele e da ausência de infraestrutura estarem ordenados no mesmo nível, sugere que os empresários veem a reforma do judiciário como um importante passo para tornar o Brasil uma economia mais competitiva.

Tabela 3.2: Ineficiência judicial ordenada contra outros problemas

\begin{tabular}{|l|c|c|c|c|c|c|c|}
\hline \multirow{4}{*}{ Mau funcionamento da justiça } & & 1 & 2 & 3 & 4 & 5 & Total \\
\cline { 2 - 8 } Carga tributária elevada & Freq. & 17 & 34 & 83 & 88 & 44 & 266 \\
& $\%$ & 6,4 & 12,8 & 31,2 & 33,1 & 16,5 & 100,0 \\
Infraestrutura física deficiente & Freq. & 198 & 43 & 13 & 4 & 8 & 266 \\
& $\%$ & 74,4 & 16,2 & 4,9 & 1,5 & 3,0 & 100,0 \\
Encargos Sociais Elevados & Freq. & 22 & 38 & 68 & 80 & 58 & 266 \\
& $\%$ & 8,3 & 14,3 & 25,6 & 30,1 & 21,8 & 100,0 \\
Mão de obra Pouco Qualificada & Freq. & 41 & 98 & 17 & 13 & 5 & 174 \\
& $\%$ & 23,6 & 56,3 & 9,8 & 7,5 & 2,9 & 100,0 \\
Altos Índices de criminalidade & Freq. & 17 & 51 & 67 & 47 & 84 & 266 \\
& $\%$ & 6,4 & 19,2 & 25,2 & 17,7 & 31,6 & 100,0 \\
& Freq. & 7 & 5 & 9 & 16 & 56 & 93 \\
& $\%$ & 7,5 & 5,4 & 9,7 & 17,2 & 60,2 & 100,0 \\
\hline
\end{tabular}

Na Tabela 3.3 apresentamos a desagregação das respostas de acordo com a natureza da propriedade e a origem do capital. Os resultados indicam que o mau funcionamento do judiciário é visto como um problema mais grave

${ }^{2}$ Este é o caso, por exemplo, de diversas pesquisas conduzidas pela Confederação Nacional da Indústria (CNI). por empresas privadas e nacionais e menos grave por empresas públicas e estrangeiras. No entanto, essas conclusões devem ser lidas com uma pitada de cautela, dado o pequeno tamanho da amostra no caso destas últimas.

Tabela 3.3: Classificação da ineficiência judicial em relação a outros problemas: desagregação por origem do capital e natureza da propriedade

\begin{tabular}{|l|c|c|c|c|c|c|c|}
\hline & & 1 st & 2 nd & 3rd & 4th & 5 th & Total \\
\cline { 2 - 8 } Companhias Privadas & Freq. & 12 & 26 & 58 & 71 & 36 & 203 \\
& $\%$ & 5,9 & 12,8 & 28,6 & 35,0 & 17,7 & 100,0 \\
Companhias Públicas & Freq. & 2 & 2 & 4 & 9 & 3 & 20 \\
& $\%$ & 10,0 & 10,0 & 20,0 & 45,0 & 15,0 & 100,0 \\
Firmas Nacionais & Freq. & 11 & 26 & 57 & 69 & 30 & 193 \\
& $\%$ & 5,7 & 13,5 & 29,5 & 35,8 & 15,5 & 100,0 \\
Firmas Estrangeiras & Freq. & 1 & 1 & 2 & 5 & 3 & 12 \\
& $\%$ & 8,3 & 8,3 & 16,7 & 41,7 & 25,0 & 100,0 \\
\hline
\end{tabular}

\subsubsection{Avaliando em que extensão o mau funcionamento da justiça afeta} a economia

Nossas terceira e quarta questões abordam a percepção dos entrevistados em relação à maneira pela qual o mau funcionamento do sistema judicial prejudica o desempenho da economia e das fumas. A resposta a ambas foi afirmativa, com a média se situando entre "prejudica um pouco" e "prejudica gravemente". Importa observar, porém, que na média os entrevistados indicaram que a ineficiência do judiciário prejudica a economia como um todo mais do que suas próprias firmas individualmente. Isso parece corroborar nossa avaliação anterior, segundo a qual, ao desenvolverem caminhos que passam ao largo do judiciário, as firmas têm a impressão de estarem insuladas em relação às deficiências do sistema. Como consequência, o mau funcionamento do judiciário é percebido como um problema difuso, afetando mais a economia do que a própria firma. 
Tabela 3.4: Impacto sobre o desempenho da economia e das firmas

\begin{tabular}{|l|c|c|c|c|}
\hline & \multicolumn{2}{|l|}{$\begin{array}{l}\text { O Sr. acha que as deficiências do } \\
\text { Judiciário chegam a prejudicar } \\
\text { gravemente o funcionamento da } \\
\end{array}$} & $\begin{array}{l}\text { E no caso específico da sua } \\
\text { empresa, o Sr. Acha que as } \\
\text { pouco ou não prejudicam em nada? } \\
\text { peficiências do Judiciário chegam a } \\
\text { prejudicar gravemente as suas } \\
\text { atividades? }\end{array}$ \\
\cline { 2 - 5 } Prejudicam \\
$\begin{array}{l}\text { gravemente } \\
\text { Prejudicam um } \\
\text { pouco } \\
\text { Não prejudicam } \\
\text { em nada }\end{array}$
\end{tabular}

\subsection{MeCANiSMOS ALternativos}

Foi sugerido que os dois mecanismos mais frequentemente utilizados pelas firmas para se protegerem dos problemas causados pelo mau funcionamento da justiça consistem na resolução das disputas por negociação direta e na cuidadosa seleção dos seus parceiros de negócios. As questões 5 e 6 tentaram desvendar como as firmas agiam a esse respeito. A questão 5 perguntou se os entrevistados concordavam com o ditado popular segundo o qual "é sempre melhor fazer um mau acordo do que recorrer à Justiça". Oitenta e oito por cento das firmas concordaram com o ditado, embora a concordância fosse apenas parcial para 51,3\% dos entrevistados (Tabela 3.5).

Tabela 3.5: Tendência a evitar os tribunais

Os empresários costumam dizer que "é sempre melhor fazer um mau acordo do que recorrer à Justiça". O Sr. concorda totalmente com essa afirmação, concorda ou discorda em parte, ou discorda totalmente?

\begin{tabular}{|l|c|c|}
\cline { 2 - 3 } \multicolumn{1}{c|}{} & Frequência & $\%$ \\
\hline Concorda totalmente & 103 & 36,9 \\
Concorda em parte & 143 & 51,3 \\
Discorda em parte & 18 & 6,5 \\
Discorda totalmente & 14 & 5,0 \\
Sem opinião & 1 & 0,4 \\
Total & 279 & 100,0 \\
\hline
\end{tabular}

A sexta questão começava por afirmar que para evitar o recurso ao judiciário, as firmas tomam precauções diversas contra quebra de contratos, fornecedores não confiáveis, clientes que não pagam, etc. Nós então pedimos aos empresários para classificarem a importância de tais precauções nos seus respectivos ramos de atividade. A questão foi formulada da seguinte maneira:

Para evitar o recurso à Justiça, as empresas costumam tomar diversas precauções contra quebras de contratos, fornecedores pouco confiáveis, maus pagadores, etc. Gostaríamos de saber como o Sr. avalia a importância de algumas dessas precauções para o desenvolvimento normal das atividades econômicas no setor em que sua empresa atua.

Os resultados mostram que (Tabela 3.6, na página seguinte):

a. Uma grande proporção dos empresários - cerca de nove em cada dez acha que os seguintes procedimentos são indispensáveis ou pelo menos importantes: checar a reputação da outra parte no mercado e seu comportamento pretérito como pagador; favorecer, nas transações comerciais, clientes e fornecedores conhecidos.

b. Exigir garantias e/ou depósitos antecipados ou evitar negócios com o setor público não aparecem como práticas tão importantes.

Estes resultados indicam que o cuidado na seleção de parceiros é o principal mecanismo utilizado pelas firmas de maneira a evitar problemas que resultem em litígios. A exigência de garantias reais ou de terceiros não é uma prática tão frequente. 
Tabela 3.6: Uso de mecanismos alternativos de proteção

\begin{tabular}{|c|c|c|c|c|c|c|}
\hline & & \begin{tabular}{c|}
$\dot{E}$ \\
indispensável
\end{tabular} & $\begin{array}{l}\text { É importante, mas não } \\
\text { muito }\end{array}$ & $\begin{array}{c}\text { Nãoé } \\
\text { importante }\end{array}$ & $\begin{array}{c}\text { Sem } \\
\text { Opinião }\end{array}$ & Total \\
\hline Consultar regularmente & Freq. & 188 & 55 & 19 & 17 & 279 \\
\hline $\begin{array}{l}\text { cadastros de devedores, } \\
\text { como SPC e Telecheque }\end{array}$ & $\%$ & 67,4 & 19,7 & 6,8 & 6,1 & 100,0 \\
\hline Dar preferência a clientes ou a & Freq. & 161 & 107 & 9 & 2 & 279 \\
\hline fornecedores conhecidos & $\%$ & 57,7 & 38,4 & 3,2 & 0,7 & 100,0 \\
\hline $\begin{array}{l}\text { Examinar como está, na } \\
\text { praca, a reputacão do }\end{array}$ & Freq. & 196 & 68 & 6 & 9 & 279 \\
\hline $\begin{array}{l}\text { interessado em determinado } \\
\text { negócio }\end{array}$ & $\%$ & 70,3 & 24,4 & 2,2 & 3,2 & 100,0 \\
\hline Exigir fiador & Freq. & $\begin{array}{c}62 \\
222\end{array}$ & $\begin{array}{l}117 \\
419\end{array}$ & $\begin{array}{c}57 \\
20.4\end{array}$ & $\begin{array}{c}43 \\
15.4\end{array}$ & $\begin{array}{c}279 \\
1000\end{array}$ \\
\hline & Freq. & 29 & 109 & $\begin{array}{c}20,4 \\
87\end{array}$ & $\begin{array}{c}1 J, 4 \\
54\end{array}$ & $\begin{array}{c}100,0 \\
279\end{array}$ \\
\hline Exigir depósito prévio & $\%$ & 10,4 & 39,1 & 31,2 & 19,4 & 100,0 \\
\hline Evitar fazer negócios com o & Freq. & 69 & 75 & 69 & 66 & 279 \\
\hline setor público & $\%$ & 24,7 & 26,9 & 24,7 & 23,7 & 100,0 \\
\hline
\end{tabular}

\subsection{IMPACTO DO MAU FUNCIONAMENTO DO JUDICIÁRIO}

\subsubsection{Avaliação qualitativa}

O mau funcionamento da justiça pode levar a um grande número de distorções na economia, como visto no primeiro capítulo. Na sétima questão, perguntamos aos empresários se em suas respectivas áreas de negócio um conjunto dessas distorções ocorria. Os resultados indicam que:

a. Aproximadamente metade dos entrevistados achou que o desempenho insuficiente do judiciário levava os bancos a aumentarem seus spreads, as empresas a não implementarem ou a diminuírem o tamanho de muitos de seus projetos de investimento, e a não terceirizarem atividades diretamente relacionadas ao processo produtivo. Em todos os casos, no entanto, os entrevistados indicaram que o efeito não era forte.

b. Mais significante é a tendência de substituir mão de obra por equipamento, aceitar acordos desfavoráveis, e não fazer negócios em estados com judiciários menos confiáveis.

c. Ainda mais forte é o efeito sobre a propensão das firmas a terceirizar atividades intensivas em mão de obra (limpeza, segurança, etc.) e a triar seus parceiros de negócios.
Tabela 3.7: Impacto do mau funcionamento do judiciário sobre a economia

\begin{tabular}{|c|c|c|c|c|c|c|}
\hline \multicolumn{7}{|c|}{ Em seu setor de atividade, o Sr. diria que a expectativa de ineficiência do Judiciário chega a causar: } \\
\hline \multirow[b]{3}{*}{ Elevação de spreads bancários } & \multirow{3}{*}{$\begin{array}{c}\text { Freq } \\
\%\end{array}$} & Não & $\begin{array}{c}\text { Sim, um } \\
\text { pouco }\end{array}$ & $\begin{array}{c}\text { Sim, } \\
\text { bastante }\end{array}$ & $\begin{array}{c}\text { Sem } \\
\text { Opinião }\end{array}$ & Total \\
\hline & & 81 & 90 & 49 & 59 & 279 \\
\hline & & 29,0 & 32,3 & 17,6 & 21,1 & 100,0 \\
\hline \multirow{2}{*}{ Não realização ou redução de investimentos } & Freq. & 106 & 95 & 48 & 30 & 279 \\
\hline & $\%$ & 38,0 & 34,1 & 17,2 & 10,8 & 100,0 \\
\hline \multirow{2}{*}{ Uso de máquinas no lugar de trabalhadores } & Freq. & 78 & 72 & 101 & 28 & 279 \\
\hline & $\%$ & 28,0 & 28,8 & 36,2 & 10,0 & 100,0 \\
\hline \multirow{2}{*}{ Aceitação de maus acordos } & Freq. & 40 & 123 & 102 & 14 & 279 \\
\hline & $\%$ & 14,3 & 44,1 & 36,6 & 5,0 & 100,0 \\
\hline \multirow{2}{*}{$\begin{array}{l}\text { Terceirização de atividades que requerem muita } \\
\text { mão de obra (limpeza, segurança, etc.) }\end{array}$} & Freq & 46 & 79 & 136 & 18 & 279 \\
\hline & $\%$ & 16,5 & 28,3 & 48, & 6,5 & 100,0 \\
\hline \multirow{2}{*}{$\begin{array}{l}\text { Cuidados especiais na seleção de parceiros de } \\
\text { negócios }\end{array}$} & Freq. & 21 & 60 & 187 & 11 & 279 \\
\hline & $\%$ & 7,5 & 21,5 & 67,0 & 3,9 & 100,0 \\
\hline \multirow{2}{*}{$\begin{array}{l}\text { Não terceirização de atividades ligadas ao processo } \\
\text { produtivo }\end{array}$} & Freq & 89 & 81 & 57 & 52 & 279 \\
\hline & $\%$ & 31,9 & 29,0 & 20,4 & 18,6 & 100, \\
\hline \multirow{2}{*}{$\begin{array}{l}\text { Não realização de negócios em Estados onde a Justiça } \\
\text { parece ser menos confiável }\end{array}$} & Freq & 76 & 66 & 91 & 46 & 279 \\
\hline & $\%$ & 27,2 & 23,7 & 32,6 & 16,5 & 100,0 \\
\hline
\end{tabular}

\section{2. Impacto sobre a firma}

Perguntamos, então, se esses problemas afetaram alguma vez a firma do entrevistado. Aparentemente, o mau desempenho do judiciário não tem impedido/inibido a maioria das firmas de investirem, nos seus próprios estados ou mesmo em outros, tampouco de fazerem negócios em outros estados ou de recorrerem à terceirização. Ele tem, no entanto, influenciado decisões tais como com quem negociar, empregar ou não mais pessoal, e negociar ou não com o setor público. A questão, cujas respostas estão apresentadas na Tabela 3.8, é lida da seguinte maneira:

O Judiciário é o Poder responsável por garantir o correto cumprimento da lei e dos contratos, proteger o direito de propriedade e defender o cidadão e as empresas contra eventuais arbitrariedades por parte do Estado. Tem-se afirmado que as deficiências do Judiciário brasileiro em certos estados aumentam o risco e/ou o custo de fazer negócios, contratar mão de obra, trabalhar com o setor público e fazer investimentos em certos estados. Gostaríamos de saber se alguma vez os custos ou a falta de confiança na agilidade ou na imparcialidade do Judiciário foram o principal fator que levou a sua empresa a: 
Tabela 3.8: Impacto da ineficiência do judiciário sobre a firma

\begin{tabular}{|c|c|c|c|c|c|}
\hline & & Sim & Não & $\begin{array}{c}\text { Sem } \\
\text { Opinião }\end{array}$ & Total \\
\hline $\begin{array}{l}\text { Não realizar um investimento que de outra forma } \\
\text { teria levado adiante? }\end{array}$ & $\begin{array}{c}\text { Freq. } \\
\%\end{array}$ & $\begin{array}{c}59 \\
21,2\end{array}$ & $\begin{array}{l}181 \\
65,1\end{array}$ & $\begin{array}{c}38 \\
13,7\end{array}$ & $\begin{array}{c}278 \\
100,0\end{array}$ \\
\hline $\begin{array}{l}\text { Não fazer negócio com determinada pessoa ou } \\
\text { empresa? }\end{array}$ & $\begin{array}{c}\text { Freq. } \\
\%\end{array}$ & $\begin{array}{l}139 \\
50,0\end{array}$ & $\begin{array}{l}109 \\
39,2\end{array}$ & $\begin{array}{c}30 \\
10,8\end{array}$ & $\begin{array}{c}278 \\
100,0\end{array}$ \\
\hline $\begin{array}{l}\text { Não empregar trabalhadores, por achar que a } \\
\text { Justiça do Trabalho é parcial em favor dos } \\
\text { trabalhadores? }\end{array}$ & $\begin{array}{c}\text { Freq. } \\
\%\end{array}$ & $\begin{array}{l}140 \\
50,4\end{array}$ & $\begin{array}{l}122 \\
43,9\end{array}$ & $\begin{array}{r}16 \\
5,8\end{array}$ & $\begin{array}{c}278 \\
100,0\end{array}$ \\
\hline $\begin{array}{l}\text { Decidir fazer um investimento em um estado em } \\
\text { vez de outro por conta dos problemas com o } \\
\text { judiciário local }\end{array}$ & $\begin{array}{c}\text { Freq. } \\
\%\end{array}$ & $\begin{array}{c}48 \\
17,3\end{array}$ & $\begin{array}{l}166 \\
59,7\end{array}$ & $\begin{array}{c}64 \\
23,0\end{array}$ & $\begin{array}{c}278 \\
100,0\end{array}$ \\
\hline $\begin{array}{l}\text { Não realizar, ou realizar poucos negócios em } \\
\text { determinado estado? }\end{array}$ & $\begin{array}{c}\text { Freq. } \\
\%\end{array}$ & $\begin{array}{c}62 \\
22,3\end{array}$ & $\begin{array}{l}150 \\
54,0\end{array}$ & $\begin{array}{c}66 \\
23,7\end{array}$ & $\begin{array}{c}278 \\
100,0\end{array}$ \\
\hline $\begin{array}{l}\text { Não terceirizar determinada atividade por receio } \\
\text { de os fornecedores não cumprirem o contrato e a } \\
\text { justiça não prover recurso em tempo hábil? }\end{array}$ & $\begin{array}{c}\text { Freq. } \\
\%\end{array}$ & $\begin{array}{c}90 \\
32,4\end{array}$ & $\begin{array}{l}140 \\
50,4\end{array}$ & $\begin{array}{c}48 \\
17,3\end{array}$ & $\begin{array}{c}278 \\
100,0\end{array}$ \\
\hline $\begin{array}{l}\text { A não realizar, ou realizar poucos negócios com } \\
\text { empresas estatais ou a administração pública? }\end{array}$ & $\begin{array}{c}\text { Freq. } \\
\%\end{array}$ & $\begin{array}{l}134 \\
48,2\end{array}$ & $\begin{array}{c}97 \\
34,9\end{array}$ & $\begin{array}{c}47 \\
16,9\end{array}$ & $\begin{array}{c}278 \\
100,0\end{array}$ \\
\hline
\end{tabular}

\subsection{REAÇÃO À MELHORIA DE DESEMPENHO DO JUDICIÁRIO}

\subsubsection{Reação qualitativa}

A seguir, perguntamos se o entrevistado achava que a melhoria na qualidade do judiciário mudaria a decisão das firmas no que diz respeito à produção, ao investimento, ao emprego etc. A questão foi feita da seguinte maneira:

Suponhamos que fosse possível reformar o Judiciário brasileiro, tornando-o equivalente em termos de agilidade, imparcialidade e custos à Justiça de países do Primeiro Mundo, incluindo-se aí sua capacidade de fazer respeitar com rapidez as suas decisões. Além disso, a Justiça do Trabalho perderia o poder que hoje tem de decidir sobre reajustes salariais e outros conflitos econômicos entre empresas e empregados. Nesta hipótese - e em função apenas dessa melhoria no Judiciário -, o senhor acreditaria que sua empresa estaria disposta a:
Tabela 3.9: Reação qualitativa ao aumento em eficiência

\begin{tabular}{|c|c|c|c|c|c|c|}
\hline & & Não & $\begin{array}{c}\text { Sim, um } \\
\text { роисо }\end{array}$ & $\begin{array}{c}\text { Sim, } \\
\text { bastante }\end{array}$ & $\begin{array}{c}\text { Sem } \\
\text { opinião }\end{array}$ & Total \\
\hline \multirow{2}{*}{$\begin{array}{l}\text { Aumentar seu volume de investimento } \\
\text { anual? }\end{array}$} & Freq. & 69 & 116 & 74 & 20 & 279 \\
\hline & $\%$ & 24,7 & 41,6 & 26,5 & 7,2 & 100,0 \\
\hline \multirow{2}{*}{$\begin{array}{l}\text { Realizar negócios maiores c/ ou com } \\
\text { maior número de pessoas e empresas? }\end{array}$} & Freq. & 46 & 100 & 114 & 19 & 279 \\
\hline & $\%$ & 16,5 & 35,8 & 40,9 & 6,8 & 100,0 \\
\hline \multirow{2}{*}{ Aumentar o número de empregados? } & Freq. & 77 & 109 & 78 & 15 & 279 \\
\hline & $\%$ & 27,6 & 39,1 & 28,0 & 5,4 & 100,0 \\
\hline \multirow{2}{*}{$\begin{array}{l}\text { Não realizar um investimento que de } \\
\text { outra forma teria levado adiante? }\end{array}$} & Freq. & 59 & 181 & 38 & 38 & 278 \\
\hline & $\%$ & 21,2 & 65,1 & 13,7 & 13,7 & 100,0 \\
\hline \multirow{2}{*}{$\begin{array}{l}\text { Não fazer negócio com determinada } \\
\text { pessoa ou empresa? }\end{array}$} & Freq. & 139 & 109 & 30 & 30 & 278 \\
\hline & $\%$ & 50,0 & 39,2 & 10,8 & 10,8 & 100,0 \\
\hline \multirow{2}{*}{$\begin{array}{l}\text { Não empregar trabalhadores, por achar } \\
\text { que a Justiça do Trabalho é parcial em } \\
\text { favor dos trabalhadores? }\end{array}$} & Freq. & 140 & 122 & 16 & 16 & 278 \\
\hline & $\%$ & 50,4 & 43,9 & 5,8 & 5,8 & 100,0 \\
\hline \multirow{2}{*}{$\begin{array}{l}\text { Decidir fazer um investimento em um } \\
\text { estado em vez de outro por conta dos } \\
\text { problemas com o judiciário local? }\end{array}$} & Freq. & 48 & 166 & 64 & 64 & 278 \\
\hline & $\%$ & 17,3 & 59,7 & 23,0 & 23,0 & 100,0 \\
\hline \multirow{2}{*}{$\begin{array}{l}\text { Não realizar, ou realizar poucos } \\
\text { negócios em determinado estado? }\end{array}$} & Freq. & 62 & 150 & 66 & 66 & 278 \\
\hline & $\%$ & 22,3 & 54,0 & 23,7 & 23,7 & 100,0 \\
\hline \multirow{2}{*}{$\begin{array}{l}\text { Não terceirizar determinada atividade } \\
\text { por receio de os fornecedores não } \\
\text { cumprirem o contrato e a justiça não } \\
\text { prover recurso em tempo hábil? }\end{array}$} & Freq. & 90 & 140 & 48 & 48 & 278 \\
\hline & $\%$ & 32,4 & 50,4 & 17,3 & 17,3 & 100,0 \\
\hline \multirow{2}{*}{$\begin{array}{l}\text { A não realizar, ou realizar poucos } \\
\text { negócios com empresas estatais ou a } \\
\text { administração pública? }\end{array}$} & Freq. & 134 & 97 & 47 & 47 & 278 \\
\hline & $\%$ & 48,2 & 34,9 & 16,9 & 16,9 & 100,0 \\
\hline \multirow{2}{*}{ Investir mais em outros estados? } & Freq. & 138 & 56 & 33 & 52 & 279 \\
\hline & $\%$ & 49,5 & 20,1 & 11,8 & 18,6 & 100,0 \\
\hline \multirow{2}{*}{$\begin{array}{l}\text { Fazer mais negócios em outros } \\
\text { estados? }\end{array}$} & Freq. & 114 & 72 & 49 & 44 & 279 \\
\hline & $\%$ & 40,9 & 25,8 & 17,6 & 15,8 & 100,0 \\
\hline \multirow{2}{*}{$\begin{array}{l}\text { Terceirizar uma maior parcela de suas } \\
\text { atividades? }\end{array}$} & Freq. & 72 & 111 & 73 & 23 & 279 \\
\hline & $\%$ & 25,8 & 39,8 & 26,2 & 8,2 & 100,0 \\
\hline \multirow{2}{*}{$\begin{array}{l}\text { Realizar mais e maiores negócios com } \\
\text { empresas estatais e a administração } \\
\text { pública? }\end{array}$} & Freq. & 69 & 90 & 77 & 43 & 279 \\
\hline & $\%$ & 24,7 & 32,3 & 27,6 & 15,4 & 100,0 \\
\hline
\end{tabular}

Os resultados indicam que:

a. Haveria um aumento moderado no volume de investimento, no número de pessoas e firmas com as quais as empresas negociam, no nível de 
emprego, na extensão do recurso à terceirização e no volume de negócios com o setor público, incluindo empresas estatais.

$b$. A decisão de se investir e/ou fazer negócios em outros estados não seria afetada de forma significativa.

De maneira geral, as respostas indicam que haveria uma mudança nas práticas empresariais, mas que essa mudança não seria dramática. A produção seria afetada de forma mais significativa (positivamente) com um aumento menos acentuado no volume de investimentos e empregos.

\subsubsection{Reação quantitativa}

A décima questão seguiu um desdobramento da anterior, perguntando o quanto os entrevistados achavam que as práticas das companhias iriam mudar com a hipotética melhora do judiciário. A questão foi assim colocada:

Para os itens da pergunta anterior em que o Sr. acredita que haveria aumentos com a melhoria do desempenho do Judiciário, mais ou menos de que percentual, relativamente aos níveis atuais, o $\mathrm{Sr}$. estima que poderia ser esse aumento?

Os resultados para essa questão são apresentados desagregados de formas diversas nas Tabelas 3.10 a 3.12 .

De maneira geral, os resultados indicam que:

a. A produção, medida como o volume de negócios, seria a variável afetada de forma mais significativa, crescendo $18,5 \%$. O aumento médio para as empresas públicas e nacionais seria um pouco maior do que aquele projetado para as empresas privadas e estrangeiras. Firmas em todos os setores indicaram que estariam inclinadas a aumentar a produção caso a qualidade do judiciário melhorasse.

$b$. Haveria um crescimento de aproximadamente $13,7 \%$ no volume de investimentos. A dispersão setorial no aumento dos investimentos é mais significativa do que aquela referente ao volume de negócios, mas todos os setores, com exceção de previdência social e seguros, indicaram que aumentariam o investimento caso o judiciário se tornasse mais eficiente.

c. O emprego também seria positivamente afetado, aumentando em 12,3\%. Nesse caso, as empresas privadas nacionais apresentaram reações mais significativas. Importantes setores em termos de utilização de mão de obra, como construção e produtos alimentícios, indicaram que experimentariam uma ampliação acima da média no que diz respeito ao nível de emprego. Vale notar que o crescimento no volume de empregos, embora não seja tão grande quanto o observado em relação à produção, sugere uma elasticidade implícita da demanda por mão de obra $(0,66)$ que é maior do que a usualmente aceita como válida para o conjunto da economia (em torno de 0,5 ).

d. Tanto o investimento como o volume de negócios em outros estados seriam apenas marginalmente afetados por um melhor judiciário: os investimentos aumentariam em 6,2\%, o volume de negócios, em 8,4\%.

e. A proporção de atividades terceirizadas subiria em $13,9 \%$. No caso de empresas estrangeiras, em 20,5\%. Esses resultados sugerem que a ineficiência judicial é uma barreira relevante a uma maior especialização da produção.

f. Finalmente, os resultados indicam que um judiciário melhor encorajaria as firmas a desenvolverem mais negócios com o setor público (13,7\% mais, em média). Na medida que os entrevistados afirmaram que o volume total dos negócios subiria em $18,5 \%$, tais resultados parecem indicar que o mau funcionamento do judiciário afeta os negócios com o setor público de forma análoga ao que ocorre com as transações com agentes privados.

Tabela 3.10: Reação quantitativa ao aumento na eficiência

\begin{tabular}{|c|c|c|c|c|c|c|c|c|c|}
\hline \multicolumn{2}{|l|}{ Aumento no: } & $0 \%$ & $<5 \%$ & 5 a $10 \%$ & 10 a $20 \%$ & $20 a 40 \%$ & $40 a 60 \%$ & $>60 \%$ & Total \\
\hline Volume anual de & Freq. & 64 & 9 & 71 & 65 & 30 & 12 & 9 & 260 \\
\hline & $\%$ & 24,6 & 3,5 & 27,3 & 25,0 & 11,5 & 4,6 & 3,5 & 100,0 \\
\hline & Freq. & 39 & 12 & 53 & 75 & 49 & 21 & 13 & 262 \\
\hline vorume de negocios & $\%$ & 14,9 & 4,6 & 20,2 & 28,6 & 18,7 & 8,0 & 5,0 & 100,0 \\
\hline Número de empregados & Freq. & 66 & 19 & 73 & 67 & 21 & 5 & 13 & 264 \\
\hline 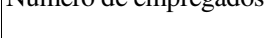 & $\%$ & 25,0 & 7,2 & 27,7 & 25,4 & 8,0 & 1,9 & 4,9 & 100,0 \\
\hline Investimento em outros & Freq. & 147 & 24 & 32 & 24 & 11 & 5 & 5 & 248 \\
\hline Estado & $\%$ & 59,3 & 9,7 & 12,9 & 9,7 & 4,4 & 2,0 & 2,0 & 100,0 \\
\hline Volur & Freq. & 122 & 21 & 41 & 39 & 15 & 7 & 6 & 251 \\
\hline outre & $\%$ & 48,6 & 8,4 & 16,3 & 15,5 & 6,0 & 2,8 & 2,4 & 100,0 \\
\hline ividades & Freq. & 59 & 20 & 59 & 71 & 29 & 13 & 9 & 260 \\
\hline & $\%$ & 22,7 & 7,7 & 22,7 & 27,3 & 11,2 & 5,0 & 3,5 & 100,0 \\
\hline Volume de negócios & Freq. & 80 & 18 & 52 & 46 & 27 & 17 & 11 & 251 \\
\hline $\begin{array}{l}\text { com estataals e } \\
\text { administração pública }\end{array}$ & $\%$ & 31,9 & 7,2 & 20,7 & 18,3 & 10,8 & 6,8 & 4,4 & 100,0 \\
\hline
\end{tabular}


Tabela 3.11: Impacto estimado do melhor desempenho do Judiciário (aumento médio em cada variável, \%)

\begin{tabular}{|l|c|c|c|c|c|}
\hline \multicolumn{1}{|c|}{ Aumento médio no } & $\begin{array}{c}\text { Todas as } \\
\text { firmas }\end{array}$ & $\begin{array}{c}\text { Firmas } \\
\text { privadas }\end{array}$ & $\begin{array}{c}\text { Firmas } \\
\text { públicas }\end{array}$ & $\begin{array}{c}\text { Firmas } \\
\text { nacionais }\end{array}$ & $\begin{array}{c}\text { Firmas } \\
\text { estrangeiras }\end{array}$ \\
\hline $\begin{array}{l}\text { Volume anual de } \\
\text { investimento }\end{array}$ & 13,7 & 13,3 & 16,8 & 13,6 & 9,8 \\
Volume de negócios & 18,5 & 18,1 & 20,1 & 18,6 & 14,0 \\
$\begin{array}{l}\text { Número de empregados } \\
\text { Investimentos em outros }\end{array}$ & 12,3 & 13,1 & 7,5 & 12,4 & 11,7 \\
$\begin{array}{l}\text { Estados } \\
\text { Volume de negócios em } \\
\text { outros Estados }\end{array}$ & 8,2 & 6,0 & 1,6 & 5,4 & 2,7 \\
$\begin{array}{l}\text { Proporção das atividades } \\
\text { terceirizadas }\end{array}$ & 13,9 & 13,8 & 13,2 & 13,4 & 20,5 \\
$\begin{array}{l}\text { Volume de negócios com } \\
\text { estatais e administração } \\
\text { pública }\end{array}$ & 13,7 & 14,0 & 10,4 & 13,7 & 12,5 \\
\hline
\end{tabular}

O que tais resultados revelam em termos do impacto agregado de uma melhora na qualidade do judiciário brasileiro? Aqui é importante estabelecermos uma diferença entre dois tipos de efeitos. Um primeiro, imediato, resulta do aumento na produção e no emprego. Um segundo, de mais longo prazo, decorre de uma maior propensão a investir, a qual, por sua vez, amplia as taxas de crescimento da produção.

Nós estimamos o efeito imediato tomando as médias ponderadas do aumento obtido para cada setor, utilizando a participação no PIB e no emprego global como pesos. Os resultados diferem dependendo do quê assumimos para os setores não cobertos pela pesquisa: agricultura, serviços fornecidos para famílias e empresas, aluguel de imóveis, administração pública e serviços não comerciais. Se propusermos que a produção e o emprego irão se expandir nesses setores a uma mesma taxa que a média das respostas obtidas na pesquisa, obtemos que a produção e o emprego irão crescer, como resultado de um judiciário melhor, em 18,6\% e 13,1\%, respectivamente. Esses valores são semelhantes à média simples obtida anteriormente, por que: (i) assumimos que importantes setores na economia apresentariam um comportamento "médio"; e porque, como aparece na Tabela 3.12, as taxas de expansão setoriais são em geral bastante similares. Se a expansão dos setores não cobertos pela pesquisa é fixada como igual à metade das taxas reportadas na Tabela 3.10, o aumento médio da produção e do emprego seria de $13,7 \%$ e 9,4\%, respectivamente. Em qualquer caso, estes são números bastante significativos, mesmo ao se levar em conta que seu impacto total só se faria sentir após um período de vários anos.

Para se estimar o impacto da melhoria do desempenho judicial sobre o investimento, seguimos um procedimento semelhante, supondo que os setores não cobertos na pesquisa expandiriam seus níveis de investimento a taxas iguais à metade daquela que foi observa da na média para os outros setores. Utilizando uma média ponderada dessas respostas setoriais (usando como pesos a participação de cada setor no investimento total), estimamos que o investimento agregada aumentaria em 10,4\%, como resultado de uma melhor performance do judiciário. A partir de um modelo simples relacionando investimento e crescimento, podemos concluir que esse aumento no investimento levaria a taxa de crescimento do PIB a aumentar em aproximadamente $25 \%$. Ou seja, esses resultados sugerem que o mau funcionamento do judiciário reduziu a taxa de crescimento do PIB em cerca de um quinto. É claro que essa é apenas uma medida aproximada. Uma estimativa precisa iria exigir, entre outras coisas, uma amostra maior, que permitisse estimar o impacto sobre o investimento setorial com alguma precisão e levar em conta as diferentes relações capital-produto em cada setor. Não obstante, o que esses valores deixam claro é que o impacto do mau funcionamento da justiça sobre o crescimento econômico é significativo. 
Tabela 3.12: Sumário das reações quantitativas à melhora da eficiência do Judiciário (aumento médio em cada variável, \%)

\begin{tabular}{|c|c|c|c|c|c|c|c|}
\hline Aumento médio no: & 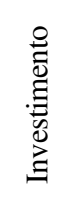 & 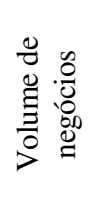 & 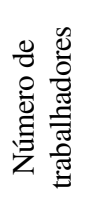 & 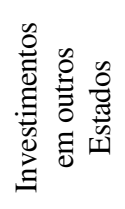 & 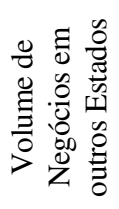 & 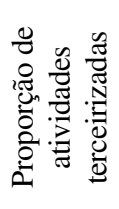 & 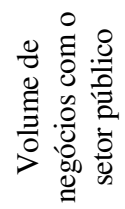 \\
\hline Mineração & 18,8 & 18,8 & 7,5 & 3,8 & 3,8 & 10,0 & 11,3 \\
\hline $\begin{array}{l}\text { Minerais não } \\
\text { metálicos }\end{array}$ & 15,0 & 15,0 & 7,5 & 10,8 & 12,5 & 8,3 & 5,0 \\
\hline Metalurgia & 13,3 & 19,3 & 13,2 & 11,5 & 16,1 & 17,4 & 18,9 \\
\hline $\begin{array}{l}\text { Maquinaria e } \\
\text { equipamentos }\end{array}$ & 15,9 & 13,3 & 8,9 & 4,7 & 9,4 & 24,4 & 11,4 \\
\hline $\begin{array}{l}\text { Equip. elétrico e de } \\
\text { comunicação }\end{array}$ & 6,6 & 9,7 & 8,4 & 1,9 & 1,9 & 14,7 & 13,1 \\
\hline $\begin{array}{l}\text { Peças e equip. de } \\
\text { transporte }\end{array}$ & 11,6 & 11,6 & 9,1 & 4,6 & 11,6 & 10,0 & 8,4 \\
\hline Madeiras e móveis & 23,3 & 28,3 & 30,0 & 13,3 & 24,6 & 22,1 & 18,3 \\
\hline Papel e celulose & 13,6 & 20,4 & 8,6 & 3,2 & 12,9 & 6,4 & 7,1 \\
\hline Plástico e borracha & 11,3 & 15,0 & 22,5 & 18,8 & 18,8 & 15,0 & 18,8 \\
\hline Têxtil e couros & 7,5 & 14,1 & 10,0 & 2,6 & 6,2 & 9,2 & 6,5 \\
\hline $\begin{array}{l}\text { Químicos e } \\
\text { petroquímicos }\end{array}$ & 13,7 & 21,2 & 13,7 & 9,1 & 10,3 & 17,1 & 13,3 \\
\hline $\begin{array}{l}\text { Farmacêuticos e } \\
\text { perfumaria }\end{array}$ & 5,0 & 9,2 & 8,3 & 4,2 & 3,6 & 7,8 & 13,6 \\
\hline Produtos alimentícios & 18,2 & 22,7 & 19,4 & 4,1 & 6,4 & 14,0 & 21,8 \\
\hline Bebidas e tabaco & 15,0 & 15,0 & 7,5 & 2,5 & 30,0 & 7,5 & 7,5 \\
\hline Construção pesada & 18,5 & 22,7 & 16,2 & 5,5 & 8,0 & 12,7 & 13,1 \\
\hline Outras construções & 20,8 & 19,8 & 19,8 & 6,9 & 7,2 & 11,6 & 19,0 \\
\hline $\begin{array}{l}\text { Serviços ind. de } \\
\text { utilidade pública }\end{array}$ & 12,1 & 13,3 & 7,8 & 3,5 & 3,9 & 16,3 & 12,4 \\
\hline Comércio atacadista & 16,0 & 20,5 & 16,0 & 11,3 & 10,0 & 9,2 & 15,2 \\
\hline Comércio exterior & 30,0 & 30,0 & 60,0 & 7,5 & 7,5 & 60,0 & 60,0 \\
\hline Comércio varejista & 13,1 & 17,3 & 8,7 & 6,9 & 9,8 & 10,2 & 11,5 \\
\hline $\begin{array}{l}\text { Distribuidor de } \\
\text { veículos e peças }\end{array}$ & 16,1 & 23,6 & 11,1 & 2,9 & 2,9 & 12,1 & 11,1 \\
\hline $\begin{array}{l}\text { Transporte e } \\
\text { armazenagem }\end{array}$ & 34,4 & 20,2 & 13,3 & 5,8 & 5,7 & 18,4 & 11,6 \\
\hline $\begin{array}{l}\text { Comunicação, } \\
\text { publicidade e gráfica }\end{array}$ & 7,5 & 20,6 & 9,7 & 2,8 & 3,8 & 12,9 & 12,5 \\
\hline Serviços gerais & 7,5 & 30,0 & 15,0 & 15,0 & 15,0 & 7,5 & 60,0 \\
\hline Finanças & 16,4 & 25,0 & 7,5 & 5,6 & 6,7 & 12,4 & 11,3 \\
\hline $\begin{array}{l}\text { Seguros e fundos de } \\
\text { pensão }\end{array}$ & 0,0 & 15,8 & 7,5 & 2,5 & 2,5 & 17,5 & 15,8 \\
\hline
\end{tabular}

\section{O PONTO DE VISTA DOS EXPORTADORES}

Vladimir Brandão

\subsection{INTRODUÇÃO}

Q oi sugerido que devido ao seu contato com o judiciário de outros países, empresários que operam em outros mercados, como os exportadores, estão melhor equipados para avaliar os custos econômicos do mau funcionamento do judiciário em países em desenvolvimento do que empresários que atuam apenas no mercado interno (Sherwood et al., 1994). Este capítulo explora essa ideia, buscando dimensionar a importância do judiciário nos negócios de empresas brasileiras que operam fora do país, detectar se empresários experientes em negócios no exterior veem o judiciário brasileiro de forma mais crítica do que os que não têm essa experiência, e comparar o judiciário do Brasil com o de outros países. Foram ouvidos empresários e executivos de grandes empresas nacionais de diversos setores, e a principal constatação foi a de que o judiciário é ignorado. Na maioria dos casos, é como se o poder judiciário simplesmente não existisse, pelo menos nos negócios de importação/exportação. Ele não é levado em conta como fator competitivo/de risco no planejamento e na realização de um negócio, e os empresários não têm interesse em se informar sobre suas características.

Para se ter uma ideia do distanciamento que rege as relações entre o mundo dos negócios e o judiciário, o advogado e diretor de Relações com o Mercado da empresa CV, o Sr. ACS, afirmou que o simples fato de responder às questões que lhe foram propostas para a realização deste trabalho poderia distorcer a importância do judiciário, dando a entender que ele seria mais relevante do que realmente é.

Nesse contexto, nos coube analisar os principais mecanismos facilitadores do comércio exterior que permitem que o judiciário seja ignorado. As cartas de crédito tendem a eliminar problemas de quebra de contrato, os difundidos seguros de responsabilidade civil afastam os

${ }^{1}$ Neste e nos dois próximos capítulos os nomes de pessoas e empresas entrevistadas foram omitidos. 
empresários de tribunais e os cada vez mais utilizados tribunais arbitrais agilizam a solução de controvérsias. Este conjunto de instrumentos constitui-se hoje numa alternativa bem mais competitiva do que o recurso ao judiciário. Há empresários que acham a arbitragem até mais justa do que a decisão judicial, pelo fato de alguns tribunais arbitrais serem especializados em determinado tipo de negócio, portanto com mais embasamento técnico para a tomada de decisões.

Quando nada disso funciona, a negociação garante, na visão de todos os empresários ouvidos, resultados bem mais satisfatórios do que os eventualmente conseguidos em tribunais. Vale ressaltar que eles afirmam isso sem jamais - ou apenas em raras oportunidades - terem enfrentado um tribunal no exterior. Mas de antemão sabem - e têm certeza disso - que ganham tempo e dinheiro negociando. Enquanto isso, no Brasil, onde as suas unidades industriais estão instaladas e as carteiras de trabalho de seus funcionários são assinadas, esses empresários não têm como escapar de litígios desencadeados por questões trabalhistas, ambientais, etc.

Esse conjunto de fatores permite concluir que esses empresários ignoram o judiciário no exterior mais que no Brasil, e que do seu ponto de vista o litígio definitivamente não compensa. Também permite concluir que o distanciamento dos tribunais não é só o resultado de um vício cultural de se tentar evitar o judiciário e priorizar a negociação, fazendo uso da máxima de que é melhor um mau acordo do que um bom processo, mas também o fruto da existência de mecanismos mais eficientes do que o judiciário.

Quanto à tendência natural à negociação, o Sr. ACS afirma que "a preocupação de se evitar o litígio - ou o judiciário - não existe por si só, ou como uma prioridade, mas pelos efeitos econômicos e comerciais que ele acarreta, qualquer que seja o caminho adotado para sua solução". Em outras palavras, o judiciário parece ser sempre - no Brasil e no exterior - o caminho mais longo e mais oneroso para a solução de problemas. Quem tem interesse em resolvê-los logo, portanto, prefere a visão negocial.

Cabe também destacar que no comércio exterior a relação cliente fornecedor é algo cultivado com carinho. Como é difícil conseguir clientes, em muitos casos formam-se relações de profunda parceria difíceis de serem abaladas devido a pequenos desentendimentos, conforme mostram alguns casos discutidos a seguir. Contribui ainda o fato de os empresários terem a certeza de que acionar a justiça no exterior é muito caro e complicado, e tem- se um bom elenco de explicações para o distanciamento dos empresários brasileiros da justiça no exterior.

Parece claro que esses empresários experientes no comércio internacional não gostam do judiciário, porque descobriram com a prática que ele, na maioria das vezes, se configura num "atraso de vida". Todos os mecanismos criados para simplificar o comércio exterior na prática viabilizaram essa atividade, que precisa da agilidade que o ritmo dos negócios impõe. Sabendo que esses mecanismos existem e fazendo largo uso deles, os empresários acabam desprezando o judiciário como um mecanismo eficaz de solucionar suas controvérsias. Têm, portanto, mais subsídios para fazer críticas não exatamente ao judiciário brasileiro, mas sim à presença do judiciário brasileiro em tantas questões que envolvem negócios. Eles são quase unânimes em sugerir, por exemplo, a rápida adoção da mediação e da arbitragem nos contratos domésticos.

Quando se trata de um investimento em outro país, o judiciário não é exatamente ignorado. Se não chega a ser analisado isoladamente pelos investidores, o risco do país é levado em consideração, e o judiciário normalmente integra o conjunto de variáveis analisadas para se chegar a esse risco. Porém, as possibilidades do mercado podem falar mais alto. Caso da empresa EMB, que se instalou na Itália e na China. A China sequer tem algo que possa ser chamado de judiciário da forma que conhecemos. "Foi uma decisão estratégica, de nos instalarmos no mercado que mais cresce no mundo", diz o seu diretor comercial.

O economista Rudiger Dornbusch declarou em certa ocasião, com base em uma pesquisa realizada por acadêmicos de Harvard, que aplicar recursos em países que não possuam o sistema jurídico da common law, característico dos países de colonização anglo-saxônica, é uma fraca estratégia de investimento devido ao baixo grau de proteção aos investidores. ${ }^{2}$ Sua afirmação parece valer mais para investimentos no mercado financeiro, tema que não está sendo abordado aqui. Nada nesse sentido foi detectado junto aos empresários ouvidos. $O$ que se pode observar é que os países nos quais as empresas ouvidas possuem subsidiárias ou filiais - Argentina, EUA, Alemanha, China, paraísos fiscais e outros - incluem tanto aqueles do sistema da common law como os da

${ }^{2} \mathrm{O}$ artigo, originalmente publicado na revista Business Week e reproduzido na Gazeta Mercantil de 28 de janeiro de 1996, fazia menção ao trabalho de La Porta et al. (1996). 
civil law, o que permite concluir que esse fator não parece decisivo na hora de se decidir onde investir no exterior.

\subsection{METODOLOGIA E SÍNTESE DOS PRINCIPAIS RESULTADOS}

Para a realização deste trabalho foram ouvidas cerca de 20 pessoas, a maioria empresários e executivos de grandes empresas. O texto a seguir e as conclusões dele tiradas foram extraídos quase que exclusivamente da matéria-prima fornecida por essas pessoas, de forma que o trabalho reflete em grande medida o ponto de vista delas. Nem todos os empresários ouvidos estão citados no texto, mas seus pontos de vista são consistentes com as conclusões aqui apresentadas. Alguns empresários procurados sequer se julgaram capazes de participar. Alegaram que o judiciário é insignificante e jamais foi levado em consideração para a realização de negócios no exterior. Opiniões, afinal, parecidas com as de quem participou.

A amostra é constituída por empresas com faturamento anual de mais de US\$ 100 milhões e experientes no comércio internacional. A justificativa é que esse tipo de empresa é que negocia os grandes volumes no exterior e importa pelo menos matéria-prima e equipamentos. Só para se ter uma ideia, somente a empresa $\mathrm{CV}$ responde por $2 \%$ das exportações brasileiras - exporta US\$ 1,1 bilhão. Juntas, as empresas SA, CV (como SA, uma exportadora de produtos alimentícios), a WE e a EMB (estas, produtoras de máquinas e equipamentos) exportam mais de US\$ 2 bilhões. Foram consultados ainda, entre outros, fabricantes de autopeças, revestimentos cerâmicos e artigos têxteis. Os produtos das empresas consultadas chegam a mais de 100 países. O fato de a maioria das empresas ser sediada em Santa Catarina e no Rio Grande do Sul não deve influir na qualidade das respostas, porque trata-se de grandes empresas, líderes em seus setores, que lidam com clientes no mundo inteiro. O parâmetro é o exterior, e não as regiões brasileiras. Acredita-se, portanto, que a amostra reflete adequadamente o que pensam os empresários e executivos de grandes empresas brasileiras com experiência em comércio internacional, até porque praticamente não houve contradição nas respostas.

Juízes não fazem parte das preocupações de quem lida com negócios internacionais. Empresários e executivos experientes em comércio exterior, via de regra, não têm experiência em lidar com a justiça de outros países. $\mathrm{O}$ poder judiciário é distante do mundo das exportações e importações porque há uma série de mecanismos que não deixam o problema chegar até ele. São desde cartas de crédito que garantem o negócio do fornecedor caso o comprador não queira ou não possa pagar, até a ampla adoção das câmaras de mediação e arbitragem que agilizam a solução de controvérsias. Juizados e tribunais não têm agilidade suficiente para acompanhar o ritmo dos negócios, e até por isso surgiram com força os tribunais arbitrais.

Quem exporta para a Europa e para os Estados Unidos tem recorrido aos seguros para evitar ser acionado por responsabilidade civil em caso de defeito de produto. Esses seguros não são tão caros quanto podem parecer a princípio. Enfim, o judiciário é praticamente ignorado no comércio exterior porque tem fama de caro e demorado, sendo na maior parte das vezes desaconselhado por consultores e advogados. É ponto pacífico que ir à justiça não compensa. Para a solução de controvérsias, a ampla preferência é pela negociação dentro da esfera cliente-fornecedor. O que mais incomoda os exportadores é o crescimento dos processos antidumping, mas não se trata de processo judicial, e sim administrativo.

“A justiça não é importante no comércio exterior", diz o Sr. LCM, presidente da empresa $\mathrm{D}$, uma fabricante autopeças que jamais enfrentou uma demanda em outro país. "Existe desconfiança no judiciário de alguns países, mas essa desconfiança jamais nos levou a deixar de realizar um negócio", diz o Sr. ACS, diretor de relações com o mercado da empresa CV. "Deixamos de fazer alguns negócios por falta de confiança, mas por falta de confiança nos clientes. Não cremos que a dificuldade em se lidar com o judiciário seja fator de limitação de nossas exportações", completa.

Quando o negócio é apenas exportar, geralmente os empresários não têm interesse em examinar o arcabouço jurídico dos países de destino das suas mercadorias. "Não costumamos fazer essa análise porque procuramos exportar somente com carta de crédito de bancos de primeira linha. Senão, analisamos primeiro o risco do cliente e depois o risco do país, a sua tradição no comércio exterior", diz o Sr. EJS, presidente do conselho de administração da WE, grande fabricante de equipamentos.

"O mais importante é ter conhecimento das normas gerais de comércio internacional e as específicas do negócio que se está realizando. Não há uma preocupação com o conhecimento específico do judiciário de cada país. É justamente por existirem diferenças entre os mecanismos judiciários dos países e as dificuldades que resultam dessas diferenças que os contratos 
internacionais padronizam a solução de litígios através de tribunais arbitrais", diz o Sr. ACS. Ele vai ainda mais longe. Para ele, sequer os negócios no mercado interno, que praticamente ainda não contam com tribunais arbitrais, exigem conhecimento do funcionamento do judiciário. "O que se exige é um conhecimento das normas comerciais e civis, mas não do mecanismo judiciário. Este ficará a cargo de advogados, se necessário".

"Deveria haver mais cuidado por parte das empresas. Quando se está vendendo para um país do terceiro mundo é adequado se cobrir. Mesmo uma carta de crédito oferece riscos, pois o banco que a garante também pode quebrar", diz o Sr. CLSP, diretor de relações como o mercado da AV e dirigente da Associação Brasileira dos Analistas de Mercado de Capitais (ABAMEC)-Sul. Ao que parece, seria prevenção demais chegar a esse ponto. Os empresários que exportam afirmam estar atentos de fato é para os seus clientes, e dependendo do tipo de negócio, no máximo se atentam para leis específicas dos países de destino de suas mercadorias. A SA, que vende grandes quantidade de alimentos para países islâmicos, tem linhas especiais de abate em suas fábricas para que os animais sejam abatidos numa posição adequada, virados para Meca, conforme reza a legislação desses países. Atualmente faz uso intensivo da Internet para se atualizar sobre as legislações sanitárias dos diversos países com os quais negocia.

Se, por um lado, os esforços são para agradar o cliente e não perdêlo, por outro,busca-se saber se eles são confiáveis para se evitar inadimplência, atraso ou calote. Existem alguns bons instrumentos para isso. As companhias que fornecem dados cadastrais de empresas inseridas no comércio internacional, por exemplo, já conseguem fornecer informações bem atualizadas. Sobre países também há fontes de informações, como a tabela da Hermes Kreditversicherungs, companhia que segura os créditos oficiais que a Alemanha oferece para importadores de seus produtos. Quanto mais calotes empresários do país importador derem, maior é o valor do seguro para aquele país - o funcionamento do judiciário não é levado em consideração para se chegar aos valores. Existem ainda as análises de grau de risco dos países, que levam em conta fatores políticos, sociais e econômicos, ou seja, a estabilidade institucional do país. A última tabela divulgada pelo The Economist antes da elaboração deste capítulo colocava o Brasil como um país de alto risco para investimentos. Mais arriscado até do que a China. Segundo a publicação, o Brasil só seria menos arriscado do que a Venezuela, o México e a Rússia.
"O comércio exterior se profissionalizou muito de alguns anos para cá", diz o Sr. LCM. Isso se deu pelo próprio aumento de negócios com o avanço da globalização, pela profusão de cursos que surgiram nessa área e por experiências como a que LCM relata. Ele conta que certa vez um americano chegou ao Brasil e se hospedou no melhor hotel de São Paulo. Convocou fabricantes de autopeças, fez grandes compras e pagou corretamente a todos. Na segunda vez, ele pediu prazo para pagar, foi atendido e até hoje ninguém viu a cor do dinheiro. Em outro caso, um grupo de pequenas empresas se uniu num pool e embarcou um razoável lote de mercadorias, mas o cliente desistiu do negócio no meio do caminho. O pool não recebeu o dinheiro e ainda teve que pagar para trazer os contêineres de volta, que ficaram abandonados no porto. "Isso não acontece mais hoje em dia. Acabou o amadorismo em comércio exterior", acredita LCM.

Pelo menos nos grandes contratos é largamente disseminado o uso de cartas de crédito, que dependendo do grau de risco, são endossadas pelos chamados bancos de primeira linha. Para que sejam firmados contratos de exportação com novos clientes ou clientes de países que têm tradição de calote, por exemplo, a carta de crédito é condição para a realização do negócio. $\mathrm{O}$ exportador recebe o dinheiro quando o produto é embarcado no navio, e quem paga a taxa que o banco cobra para emiti-la muitas vezes é o importador, não onerando assim a exportação.

"Essas cartas eliminam o risco de calote. Todos os negócios realizados em nosso setor são feitos com carta de crédito", afirma LM, dirigente da Associação Brasileira de Exportadores de Frango (ABEF) e da Associação Brasileira de Exportadores de Suínos (ABECS). Um exemplo dessa tranquilidade garantida pela carta de crédito é o da empresa SA, que recentemente passou a negociar com a Rússia, um país com notórias deficiências jurídicas. Os negócios são feitos com carta de crédito.

O juízo arbitral, por sua vez, tem aparecido cada vez mais nos contratos, e com muita frequência a sua adoção traz expressa a proibição de se recorrer à justiça comum. Só para citar um exemplo, toda a atividade de exportação do complexo de cereais utiliza contratos adotados pela Associação Nacional dos Exportadores de Cereais (ANEC). Esses contratos remetem a solução de litígios para a Câmara Arbitral do Grain and Feed Trade Association (GAFTA) em Londres. Se a importação for feita pelos Estados Unidos, o contrato adotado é o NAEGA 2, da North American 
Export Grain Association, cuja câmara arbitral competente é a da American Arbitration Association. Até na Argentina os tribunais arbitrais são desenvolvidos. A Corte de Arbitraje de la Camara de Comércio Internacional de la Ciudad de Buenos Aires é indicada como foro de solução de controvérsias em todos os contratos celebrados na capital portenha.

"O foro dos contratos mais importantes feitos hoje em dia é a câmara de arbitragem", afirma LCM. "Esses tribunais têm se mostrado ágeis, práticos e de baixo custo", diz ACS. "Entre nós, o mesmo sistema de solução de litígios deve se instalar rapidamente, especialmente agora com o Mercosul e com a experiência exitosa da Argentina", completa. Mas a experiência com esse mecanismo extrajudicial não é positiva para todo mundo. A empresa SA teve que esperar quatro anos para que fosse resolvida uma controvérsia por um juízo arbitral em Milão (Itália). Há empresários que duvidam da imparcialidade desses tribunais, achando que eles tendem a beneficiar as grandes corporações internacionais. O fato concreto, porém, é que o mecanismo é cada vez mais utilizado.

Se hoje, em muitos casos, a quebra de contrato é um fator de risco minimizado, em função do uso de cartas de crédito e das relações de parceria com os clientes, de uns tempos para cá surgiu com força uma outra dor de cabeça para os exportadores. Trata-se do liability, ou a responsabilidade civil, que só começou a se tornar realidade no Brasil com o código do consumidor, de maneira ainda muito incipiente. "No exterior é uma grande preocupação, dada a permanente ideia fixa das pessoas físicas e jurídicas por indenizações, principalmente nos Estados Unidos e na Europa. Temos apólice contra ações que possam ocorrer", diz o Sr. GK, diretor comercial da EMB, grande fabricante de equipamentos. Por conta do seguro, a empresa não enfrentou nenhuma ação por perdas e danos. "A responsabilidade civil em função de produto é um dos tipos de processo mais prováveis para os quais devemos nos preparar", diz EJS, da WE.

"Nesses países, se alguém escorregar em um piso e cair é capaz de processar o fabricante, mesmo que não haja problema algum com o produto", diz o Sr. RW, presidente da fabricante cerâmica TC. Por conta disso, a empresa $\mathrm{P}$, da qual foi superintendente, também produtora de cerâmica, tem seguro desde 1984. Não é um seguro caro. Para se ter uma ideia, todas as exportações da WE - US\$ 100 milhões anuais - estão seguradas por um valor anual de US\$ 250 mil. O que sensibilizou a empresa para a importância desse seguro foi o fato de ter sido acionada pela justiça canadense por perdas e danos. Um acidente envolvendo um motor fabricado pela WE acabou provocando uma explosão em uma empresa fornecedora de gás. A empresa canadense ingressou com ação de perdas e danos no valor de US\$ 900 mil e lucro cessante de US\$ 3 milhões contra a instaladora, a empresa que faz a manutenção, a empresa de engenharia e a WE. O processo está em andamento. $\mathrm{O}$ acidente ocorreu há dois anos e, até então, a WE não tinha seguro.

Há, portanto, vários mecanismos que ajudam os empresários a se manterem longe dos juízes. Mesmo que por algum motivo eles não sejam eficientes o bastante, é ponto pacífico entre os exportadores que a justiça em outros países - em princípio em qualquer país - deve ser evitada. As justificativas são o custo e o tempo. "É muito caro entrar na justiça no exterior, e quando alguém pede uma consultoria, quase sempre o conselho é esquecer o prejuízo. Geralmente tem que se contratar um advogado aqui e outro no exterior, tem que fazer procuração, é caro. Só vale a pena se os valores em jogo forem muito altos", diz o chefe do Centro Internacional de Negócios da Federação das Indústrias do Estado de Santa Catarina (FIESC). Para se ter uma noção desses custos, a WE pagou US\$ 200 a hora para os advogados que a defenderam em uma ação movida contra ela nos Estados Unidos.

O Sr. HHM, advogado especializado em marcas e patentes, tem a mesma opinião quando o assunto é a pirataria de marcas. "Às vezes é tão complicado acionar o judiciário de outros países que vale mais a pena comprar a marca de volta", diz. A empresa HE tomou esse caminho há tempo. Em 1978, ela comprou sua marca na Argentina, pois os seus produtos estavam sujeitos a busca e apreensão em Buenos Aires. O proprietário pediu US\$ 100 mil, e a HE fechou negócio por US\$ 40 mil. A empresa MC gastou US\$ 100 mil há cerca de dois anos para reaver sua marca no Uruguai, que estava registrada pelo seu próprio distribuidor. A WE comprou a marca WE no Japão e na Alemanha. "Fizemos acordos amigáveis", diz o Sr. EJS. Atualmente a WE tem a marca registrada em mais de 70 países.

A negociação é a saída preferida para solucionar controvérsias, mesmo que uma das partes se julgue com total razão e dê como certo o ganho de causa, o que deixaria os custos na mão do perdedor. "O problema é que enquanto o processo está em andamento é necessário fazer uma série de adiantamentos, o que acaba provocando um saldo desvantajoso", diz RW. A empresa P certa vez comprou na Itália um equipamento avaliado em US\$ 3 
milhões. O contrato era para sete meses e, nesse meio tempo, houve uma supervalorização da lira. Com isso o vendedor arcaria com um prejuízo de cerca de $25 \%$ do valor do contrato, e se recusou a entregar a máquina. Num primeiro momento, a empresa brasileira pensou em fazer uso do contrato, que lhe dava direito a receber o produto por aquele valor, e entrar com uma ação judicial contra o fornecedor. Só que voltou atrás. "Concluímos que iria ser mais demorado e oneroso entrar em foros internacionais do que negociar", diz o Sr. RW. Cada uma das partes cedeu um pouco e o negócio acabou sendo concretizado sem a intervenção judicial.

Num outro caso, a empresa $\mathrm{P}$ vendeu um lote de produtos para os Estados Unidos e o cliente se recusou a pagar, alegando defeito. A empresa brasileira mandou técnicos aos Estados Unidos, que, de acordo com RW, não encontraram defeito algum. "Pensamos em ir para a briga judicial, mas concluímos que iria ser muito complicado. Acabamos dando um desconto no preço", diz. O que acaba valendo aí é um velho chavão. "É preferível uma má negociação do que um bom processo. Este significa sempre muito tempo e dinheiro", acredita o empresário. Essa é a opinião de nove entre dez empresários.

Praticamente todos os problemas de rejeição de produtos e compra de tecnologia da empresa $\mathrm{P}$ eram resolvidos sem o envolvimento de advogados. Na verdade, durante o tempo em que RW esteve à frente da empresa, o seu advogado nos Estados Unidos só foi acionado uma vez, quando a empresa quis desfazer um contrato com um representante em Porto Rico. A negociação é uma arma tão poderosa para agilizar os negócios que a empresa SA tomou como uma grande lição aquela longa espera por uma arbitragem em Milão. Ficou quatro anos sem negociar com uma empresa com a qual faz muitos negócios hoje. A empresa brasileira acredita que se tivesse resolvido o problema através de um acordo teria ganho muito mais.

O Sr. AF, consultor e ex-executivo da empresa AX, uma grande empresa têxtil, nunca tomou conhecimento de problemas jurídicos em exportações de artigos têxteis. "Os problemas são resolvidos na esfera cliente-fornecedor", diz. Nesse sentido, a empresa AX passou por experiências interessantes. Um lote de produtos entregue a um dos maiores fornecedores por catálogo da Alemanha estava defeituoso. Ao serem lavadas, as peças liberavam um odor desagradável, devido a um problema com os produtos químicos utilizados. O cliente da $\mathrm{AX}$ não teve dúvidas e recolheu rapidamente todo o lote, temendo sofrer pesadas ações judiciais. "Se isso acontecesse, ele procuraria transferir o problema para o fabricante", diz AF. "Sofreríamos pressão até mesmo a ponto de parar a produção. Na época, não tínhamos dúvidas de que a justiça nos imporia uma pena forte", diz.

Obviamente havia outra questão em jogo. Se a $\mathrm{AX}$ não fizesse imediatamente a reposição do lote, perderia um grande cliente e Ficaria com uma imagem manchada no mercado. Ganhar clientes na Europa não é fácil, e acaba sendo mais negócio manter a qualquer custo os que já estão em carteira. Assim, a reposição foi feita rapidamente. Num outro caso, a AX teve problemas de atraso na entrega de um lote de roupas para os Estados Unidos e tomou uma decisão na mesma linha da anterior. Para não correr o risco de se indispor com o cliente, que já havia distribuído catálogos com os artigos, a empresa brasileira colocou a encomenda em um avião, teve prejuízo com a venda, mas ficou de bem com o mercado. A empresa SA chega a proteger com air bags suas carnes, porque um lote que estava em um navio que enfrentou uma tempestade foi danificado e houve reclamação do importador. Esse tipo de procedimento é comum entre os exportadores, o que afasta as possibilidades de pendengas jurídicas.

Mas vale dizer que essa relação existe entre as grandes empresas e clientes de países desenvolvidos. Quando o mercado, as leis e a justiça de um país são menos exigentes, via de regra ele acaba servindo de destino para lotes de produtos problemáticos - que muitas vezes tinham como destino exatamente a Europa ou os Estados Unidos. Essa desova geralmente é feita no Mercosul. "É muito mais fácil exportar para a Argentina do que para a Alemanha. No Mercosul é raro se enfrentar problemas com produtos fora da especificação ou de responsabilidade civil", diz uma fonte ligada ao setor têxtil.

Se o judiciário de um país, enquanto fator isolado, não é levado em consideração em negócios de importação e exportação de grandes empresas, quando se trata de um investimento no exterior a coisa pode mudar de figura. O Sr. CLSP, da ABAMEC, afirma que nesses casos geralmente se analisa uma série histórica de como foi feito o tratamento das leis pelo judiciário e se faz um levantamento das jurisprudências. Além, é claro, de outros itens como as próprias leis. "Existem bancas de advogados que fazem isso. Em alguns casos, a própria embaixada do Brasil no país dispõe desse tipo de informação", diz CLSP. 
Ele conta que, há alguns anos, a empresa em que atuava resolveu abrir subsidiárias no México e em Portugal a fim de contornar experiências malsucedidas com representantes, e mandou fazer esse tipo de análise. Ela determinou que os dois países têm estrutura adequada para a realização de negócios internacionais. Para CLSP, os países do G7 e do Mercosul têm o mesmo perfil. "Há exceções como a França, no caso dos frangos. Como o governo subsidia a produção, geralmente quem exporta para lá enfrenta processos antidumping. A segunda instância desse processo administrativo é o judiciário, e ele sempre legitima o protecionismo francês. Dessa forma, o judiciário acaba sendo um inibidor para as vendas". Vale argumentar nesse caso que o fator inibidor é o protecionismo enquanto posição do país, e não uma atitude isolada do judiciário.

Às vezes, entretanto, o mercado fala mais alto do que o chamado risco sistêmico de um país, que é o conjunto de fatores que propicia ou inibe os negócios e do qual faz parte o judiciário. A empresa EMB, que exporta para mais de 60 países e tem duas fábricas na Itália, resolveu ampliar os seus negócios se instalando na China, país tido como de alto risco pelo mercado. Fez isso através de uma joint-venture firmada com uma companhia estatal em 1996. "Foi uma decisão estratégica, de estar no mercado onde há maior expansão no mundo", diz o diretor comercial Sr. GK. "Quem for para a China deve estar preparado para atuar numa cultura completamente diferente, num país fechado, hermético. A falta de leis claras e de um aparato jurídico são as maiores dificuldades. No Ocidente já existe uma cultura de lei, pode-se invocar a lei. Lá não. O que está escrito em um contrato pode não valer, e não há como exigir ou chamar as empresas à responsabilidade. Só agora estão começando as mudanças nesse sentido. O que dá maior segurança é o desejo da China de fazer parte da Organização Mundial do Comércio e com isso estabelecer regras claras em relação a impostos, tributos e aplicação das leis. Mas a China é uma aposta, um negócio de risco com retorno razoável", diz o Sr. RCL, gerente de vendas internacionais para o Extremo Oriente, África e Oriente Médio da EMB. A empresa não mantém departamento jurídico no país. Todas as questões ficam a cargo de seu sócio estatal.

O judiciário muitas vezes é ignorado nos negócios internacionais, como já foi visto, já que entre outros mecanismos existe a carta de crédito. Mas é comum se deixar de fazer negócios por não haver carta de crédito, quando a negociação se dá com países com alto grau de risco. O Sr. LCM foi vítima de um calote de uma empresa da Bolívia, e perdeu a confiança no cliente andino e no país. "Hoje só faço negócio com eles com carta de crédito. Sem carta, nada feito", diz.

Alguns países são um verdadeiro terror para os empresários. "Quem vende sem carta de crédito para a Nigéria não recebe e não tem a quem recorrer. É humanamente impossível receber", exagera o Sr. RW. Outro desses países-arapucas é o Paquistão. Em 1995, surgiu entre as empresas de Blumenau (SC), que concentra um grande polo têxtil, uma febre de importação de fios e tecidos do Paquistão, produtos com preço muito bom. A empresa SL, uma das maiores da região, recebeu um pequeno lote, de boa qualidade, e fez um grande pedido em seguida. Só que todo o material era de péssima qualidade. A empresa entendeu que não tinha como recorrer, e acabou arcando com o prejuízo.

O algodão russo também aparentava ser um bom negócio, mas as empresas, vacinadas, preferiram esperar por outras oportunidades de negócios. A AX, por exemplo, só comprou quando uma empresa brasileira entrou no circuito. "Geralmente só se compra produtos asiáticos se houver uma triangulação, que quase sempre é assumida por empresas de comércio exterior europeias", diz o Sr. AF.

Fica a questão: se a justiça boliviana fosse ágil, barata e imparcial, garantindo eficazmente o cumprimento do contrato, será que não seria possível que o Sr. LCM incrementasse os seus negócios com o país? E se os empresários de Blumenau tivessem a quem recorrer no Paquistão, eles não poderiam continuar comprando de lá? E se os empresários pudessem comprar com mais segurança dos asiáticos que tanto temem? E se o judiciário russo fosse eficiente, será que a SA não poderia exportar a mais tempo para lá? "Se houvesse um poder judiciário mais ágil e que fosse capaz de forçar um importador a cumprir suas obrigações, poderia até haver um aumento de vendas para o país", diz LCM.

O que parece acontecer nesses casos é o seguinte: mecanismos extrajudiciais facilitaram as relações comerciais entre países de maneira tal que praticamente alijaram o judiciário do processo, e por isso ele é ignorado. Se não existem os mecanismos extrajudiciais, o negócio tende a nem ser feito. Se for feito, é realizada uma análise do cliente, da tradição do país e do grau de risco do país. O judiciário pode até ser um componente desse grau de risco, mas enquanto fator isolado não parece ser considerado. 
É difícil dimensionar quanto se poderia vender a mais se houvessem judiciários eficientes que dessem mais segurança nos negócios. $\mathrm{O}$ Ministério da Indústria e Comércio, quando foi regulamentado o seguro de crédito à exportação, informou que, graças ao seguro, as exportações brasileiras poderão crescer, por ano, US $\$ 500$ milhões. Pode-se deduzir, então, que no mínimo esse valor deixa de ser vendido por falta de segurança - não exatamente no judiciário, mas em clientes e países. O seguro cobre riscos econômicos e políticos. Entenda-se por riscos econômicos a inadimplência do importador por prazo igual ou superior a 180 dias, a insuficiência dos seus bens após a execução judicial e a falência ou concordata do importador. Quanto ao risco político, trata-se de moratória do país de domicílio do importador ou a proibição de remessa de divisas para o exterior; guerra civil ou revolução que impeça pagamento do débito; ou ainda a impossibilidade de pagamento de débitos devido a terremotos, maremotos e outros fenômenos naturais.

\subsection{UMA AVALIAÇÃO COMPARADA DO JUDICIÁRIO BRASILEIRO}

Considerando-se que os empresários brasileiros têm muito pouco ou nenhum contato com a justiça no exterior, fica difícil, por parte deles, uma comparação do judiciário brasileiro com o de outros países. Ao tentar descobrir se o empresário com experiência internacional vê o judiciário brasileiro de forma diferente dos que não têm essa experiência, aparecem algumas surpresas. É que o pouco contato com a justiça devido aos tribunais arbitrais, cartas de créditos etc. significa agilidade nos negócios, às vezes maior do que a que se tem no mercado interno, sujeito a um judiciário moroso. Daí a crítica ao judiciário brasileiro.

Eis algumas das impressões colhidas sobre o judiciário de alguns países e o brasileiro:

* A empresa WE se envolveu numa demanda jurídica nos Estados Unidos em 1982. O ocorrido deu ao Sr. EJS, fundador e presidente do conselho de administração da empresa, a certeza de que a justiça norte americana é bastante eficiente nas questões que envolvem negócios. A WE moveu um processo contra seu distribuidor, que tinha exclusividade para todo o território norte-americano, com contrato de cinco anos. A empresa brasileira rompeu unilateralmente o contrato porque o distribuidor não liquidou nos vencimentos as cambiais devidas. Como o contrato elegia o município sede da WE, em Santa Catarina, como foro, a empresa propôs a rescisão contratual no Brasil. O distribuidor não contestou e o processo foi julgado à revelia.

Mas o distribuidor ingressou com uma ação de indenização por quebra de contrato contra a WE nos Estados Unidos, alegando que não aceitou a cláusula de foro, que o contrato fora rescindido unilateralmente e que a legislação brasileira não oferecia proteção adequada à empresa americana. A citação da WE foi feita através de um escritório de advocacia do Brasil. Vale dizer que a citação inicial foi feita sem carta rogatória - a solicitação que um juiz ou tribunal de um país faz a outro para que se cumpram atos processuais que escapam à jurisdição da autoridade solicitadora. A WE procedeu à defesa nos Estados Unidos e, diante das provas produzidas no processo, o advogado americano contratado acabou efetuando um acordo, cobrando o débito do distribuidor e considerando rescindido o contrato, sem julgamento de mérito.

EJS, na época presidente executivo da WE, ficou com uma impressão positiva da justiça norte americana. "A grande vantagem é na parte processual", diz. Ele destaca o fato de que a citação inicial é feita pelo advogado, que merece fé pública, sem interferência de funcionários da justiça. "Isso permite uma maior celeridade nos processos", diz. Outra característica que o impressionou é que não há a obrigatoriedade de traduções de documentos - os documentos normalmente utilizados nas transações comerciais são suficientes para se instruir os processos. "No Brasil se exigiria tradução juramentada de todos os documentos. Além disso, qualquer citação ou intimação é feita para o exterior com carta rogatória, via relações exteriores. Já no exterior a empresa é citada diretamente pelo advogado da parte contrária”, explica o empresário.

Analisando comparativamente o judiciário brasileiro, EJS faz as suas críticas. "O Brasil tem um sistema processual bem estruturado, porém peca quanto ao cumprimento dos prazos pelos juízes, promotores e outros auxiliares da Justiça, tornando o processo moroso e oneroso. Além disso, deveria se atribuir fé pública aos advogados para permitir maior celeridade no processo, sem que haja necessidade de citações através de oficiais de justiça e escrivães".

* O Sr. LCM, presidente da D, acha que um ponto negativo no Brasil é o fato de haver um direito ilimitado de julgar, dada a falta da súmula 
vinculante, a jurisprudência. "O judiciário americano trabalha com a lei e com a jurisprudência da Suprema Corte. O poder é limitado a saber se há jurisprudência e aplicá-la. No Brasil a máquina gera sentenças que somente geram demandas". Outro problema, segundo ele, é que aqui os juízes não têm prazo para julgar, o que provoca enormes prejuízos à atividade econômica. Cita como exemplo o caso de uma empresa que extraviou uma mercadoria importada pela D em 1981, e por isso a empresa ficou dois meses sem faturar. Demandou contra essa empresa e até hoje não houve julgamento definitivo - 0 recurso está há sete anos no STJ. Segundo os cálculos da D, seu prejuízo foi de US\$ 2,5 milhões. Mas se hoje ela ganhar tudo que pretende, pelos critérios de correção vigentes, receberia apenas US\$ 1 milhão.

LCM tem ojeriza à Justiça do Trabalho no Brasil. A quitação de horas-extras, por exemplo, não vale nada para a Justiça. "Ela serve bem ao mau empregado e ao mau empregador". Por exemplo: em qualquer demanda o advogado do trabalhador interpõe um perito. Isso, na visão de LCM, já torna o laudo parcial porque o perito tende a condenar a empresa. "Como é a parte sucumbente que paga e o trabalhador não tem dinheiro suficiente, o perito já de cara condena a empresa. O centro da demanda passa a ser o perito e não o juiz", diz. "Se há área que está pedindo arbitragem é a trabalhista".

Segundo ele, a figura Justiça do Trabalho não existe na maioria dos países. Essas questões são julgadas pela justiça comum e há liberdade de contrato entre empregado e empregador. O contrato de trabalho nos EUA é pequeno. Grande é a execução do contrato. Enquanto o contrato diz quanto se paga de horas-extras, a execução diz a forma e o dia do pagamento, por exemplo. No Brasil, esta parte da execução não depende do contrato, mas sim da lei. Certa vez LCM fez um acordo com os seus funcionários para que o intervalo para a refeição fosse menor, de apenas meia hora. $\mathrm{O}$ sindicato dos trabalhadores apoiou o acordo, mas a Delegacia Regional do Trabalho acabou multando a companhia. "A lei é minuciosa demais".

* O advogado ACS, diretor da empresa CV, acha que o judiciário brasileiro precisa passar por profundas reformas que lhe permitam atender minimamente as suas funções essenciais. "Ele está totalmente divorciado da realidade atual, especialmente no que diz respeito à atividade econômica e à dinâmica em que atuam os seus agentes. Não é só a inaceitável morosidade, o excesso de formalismo, o descompasso de seu aparelhamento, um código de processo desatualizado e tantas outras falhas, mas o que ocorre de mais grave é uma distorção que nos parece cultural. Trata-se de um problema de mentalidade que envolve nossos juizados e tribunais, completamente distanciados da realidade em que se desenvolve nossa atividade econômica e na qual temos que competir arduamente para sobreviver. As dificuldades, quando se necessita de uma decisão rápida sobre um assunto bastante especializado, quer de natureza industrial, comercial ou mesmo tributária, são intransponíveis e fatalmente a justiça não será realizada. Embora a maioria desses problemas não seja exclusividade do judiciário brasileiro, em poucos países eles se apresentam de forma tão acentuada. Não é por outra razão que na generalidade dos países se tem adotado os tribunais arbitrais como o foro adequado para solução de controvérsias, com resultados práticos muito mais eficientes - e até mais justos - do que no judiciário comum".

* A experiência do Sr. RW lhe dá uma noção de como a justiça funciona nos Estados Unidos e na Itália. Sua impressão é que o dia-a-dia das empresas é muito menos dependente dos advogados. As amarras jurídicas são muito mais fáceis de desatar. $O$ próprio sistema legal é bem mais simplificado. Quanto a custos, ele considera caríssimo um advogado nos EUA. "Ele cobra por hora, sentou na sua frente dispara o cronômetro", diz. "Em compensação, precisa-se do advogado por menos tempo. Acredito que, em caso de calote, nos Estados Unidos, as chances do exportador reaver o dinheiro são muito boas". 


\section{O JUDICIÁRIO E AS MICRO E PEQUENAS EMPRESAS}

Eunice Nunes

\subsection{INTRODUÇÃO}

$\mathrm{E}$

ste capítulo descreve o relacionamento das micro e pequenas empresas com o judiciário e o impacto desse relacionamento sobre as suas atividades. Para contextualizar a discussão, foi preciso buscar informações sobre o número dessas empresas no Brasil. Além disso, mostrou-se necessário conceituar esses dois tipos de empresa e examinar a sua distribuição por setor de atividade. O contexto e os conceitos relevantes para a compreensão da discussão que segue são apresentados na segunda seção do capítulo.

Ao todo, foram entrevistadas 12 empresas de diversos ramos de atividade: comércio, indústria e prestação de serviços. Entre as questões abordadas, destacam-se: as dificuldades de acesso ao judiciário, a incidência da litigação vs. acordo, as situações que levam à litigação, e como essas empresas resolvem os problemas decorrentes da falta de conhecimento jurídico. Os casos mais interessantes do ponto de vista da compreensão do papel do judiciário na vida das empresas de pequeno porte são descritos na seção 3 .

A tentativa de quantificar a litigação judicial no universo de micro e pequenas empresas não obteve sucesso. Os bancos de dados do Poder Judiciário consultados não contêm a informação de quantas ações foram ajuizadas por essas empresas. Eles informam apenas o número de processos por tipo de ação: mandado de segurança, habeas corpus, etc.

\subsection{CONTEXTO E CONCEITOS}

O SEBRAE (Serviço Nacional de Apoio à Pequena Empresa) estima em 3,5 milhões o número de micro e pequenas empresas no Brasil. É quase impossível chegar a um número preciso, porque é comum empresas abrirem e depois fecharem sem dar baixa nos órgãos competentes. A entidade tem adotado o critério clássico do número de empregados para classificar as empresas em micro, pequena, média e grande, embora o conceito fiscal seja baseado no faturamento anual. Nos setores de comércio e prestação de serviços é considerada microempresa aquela que tem até 9 empregados. A pequena vai de 10 a 49 funcionários. Já na indústria, enquadra-se como microempresa aquela que tem até 19 empregados e, como pequena, a que emprega entre 20 e 99 pessoas.

Estudo do SEBRAE indica que cerca de $90 \%$ dos estabelecimentos do país são microempresas. O mesmo estudo dá uma ideia aproximada de como se distribuem, por setor de atividade, as micro e pequenas empresas, assim classificadas pelo critério do número de empregados. Segundo a projeção do SEBRAE, $50 \%$ dos estabelecimentos do país concentram-se no comércio. Nesse universo de estabelecimentos comerciais, 90,3\% são microempresas e $9 \%$ são pequenas empresas. Na indústria, as microempresas constituem $81,4 \%$ dos estabelecimentos e as pequenas $13,6 \%$. No setor de prestação de serviços, $93,6 \%$ são microempresas e $5,4 \%$ pequenas.

Pelo critério fiscal de classificação, microempresa é a que fatura por ano até $\mathrm{R} \$ 120$ mil. A pequena empresa é aquela cujo faturamento anual vai de $\mathrm{R} \$ 120$ mil a $\mathrm{R} \$ 720$ mil. O SEBRAE começou agora a trabalhar também com esse critério fiscal, em função da implantação, em 1998, do sistema federal de tributação simplificada para esses dois tipos de empresa. A tendência, daqui para a frente, é usar apenas a classificação fiscal. Enquanto isso não acontecer, fica difícil conceituar com precisão o que é micro e pequena empresa. Neste trabalho foi adotado o critério tradicional do número de empregados na escolha das empresas consultadas, por ser aquele que ainda predomina nas pesquisas do SEBRAE.

\subsection{O ESTUDO}

As micro e pequenas empresas, de modo geral, não recorrem ao judiciário, a não ser quando, processadas ou autuadas, precisam defender-se. Elas procuram resolver seus conflitos pela via consensual, preferindo até um mau acordo a verem-se às voltas com a justiça. Isso porque elas não têm confiança no judiciário, especialmente devido à sua lentidão, e por ser cara a contratação de um advogado. 
As pequenas empresas não costumam ter departamento jurídico, nem contratar serviços de consultoria jurídica. É o contador que acaba fazendo o papel de consultor e suprindo às vezes o advogado nessa função. O contador informa à empresa sobre as mudanças na legislação trabalhista, tributária etc., e diz como a empresa deve proceder. Além disso, em caso de autuação fiscal, quem costuma fazer a defesa nas instâncias administrativas é o contador.

A maioria dos litígios judiciais em que estão envolvidas as pequenas empresas é trabalhista. Neste caso, são elas as acusadas e, obviamente, precisam defender-se. Portanto, não se trata de uma iniciativa delas, ou seja, não são elas o sujeito ativo do processo. A ida ao judiciário é apenas uma reação à reclamação trabalhista do empregado.

Basicamente, as micro e pequenas empresas costumam tomar a iniciativa de recorrer ao judiciário em duas situações:

1. Quando têm débitos tributários e não podem ou não querem pagá-los. Entram então na justiça e adiam o pagamento enquanto durar o processo, o que pode demorar sete anos ou mais.

2. Quando são indevidamente autuadas e, para defender-se da autuação injusta, vão ao judiciário contra o ato administrativo.

Em outras questões, elas evitam ir à justiça. Veem com descrédito e desconfiança o desempenho do judiciário, devido à demora da decisão judicial. Afirmam que, via de regra, não compensa (é cara a contratação de um advogado), mesmo quando há a certeza de ganhar a ação. Neste Ultimo caso enquadram-se, por exemplo, ações contra a cobrança de tributos já julgados inconstitucionais pelo Supremo Tribunal Federal (STF), como a mudança da base de cálculo do PIS (Programa de Integração Social) e os compulsórios sobre combustíveis e automóveis novos. Nenhuma das empresas entrevistadas sequer entrou com ação para reaver o que pagou indevidamente. Elas avaliam que o custo do processo é maior do que o valor do imposto a ser devolvido.

Algumas até chegaram a avaliar a hipótese de discutir judicialmente a cobrança de alguns impostos, mas desistiram diante da possibilidade de ter de depositar em juízo o valor contestado. O raciocínio é o seguinte: já que vão ter de dispor do dinheiro de qualquer maneira, pagam de uma vez. Assim não têm de gastar dinheiro com advogado e custas processuais.
Outras, depois da declaração da inconstitucionalidade do tributo pelo STF, simplesmente param de pagá-lo.

Fora da órbita trabalhista e tributária, o principal problema enfrentado pelas micro e pequenas empresas é a falta de pagamento de contas a receber. Neste caso, elas sempre procuram encontrar uma solução negociada. Mesmo o pedido de falência, que vem sendo banalmente usado como instrumento de pressão contra o devedor, quase não é utilizado pelas pequenas empresas. ${ }^{1}$ Elas negociam com o devedor, fazem acordo de parcelamento da dívida, mas procuram resolver o problema entre eles. $\mathrm{O}$ máximo que costumam fazer é protestar em cartório o título de crédito.

A seguir, alguns casos ilustram os fatos descritos acima.

\section{Caso 1}

O Instituto FG foi fundado em 1976 e conta com três sócios e 27 funcionários. A empresa já teve envolvimento com o judiciário na área trabalhista e tributária. Quando se defronta com alguma controvérsia em outros campos do Direito tem optado pela negociação.

Como é empresa que presta serviços médicos, a maior parte de seus pacientes chega por intermédio de convênios de assistência médica ou empresas de seguro-saúde. E são estas empresas que pagam pelos serviços prestados pelo Instituto. Às vezes, algumas destas empresas passam por dificuldades financeiras e atrasam os pagamentos. Alguns atrasos chegam a seis meses. A decisão do Instituto foi sempre negociar e chegar a um acordo para o pagamento, com o propósito de parcelar a dívida, fazer um desconto, ou ambos.

A atitude de negociar baseia-se na constatação de que cobrar na justiça demora sempre mais tempo do que a realização de um acordo e não garante o recebimento da dívida (o devedor sempre pode arrumar formas de protelar o pagamento). Além disso, o embate judicial pode levar à perda do cliente, enquanto o acordo é visto como uma forma mais cordial de resolver o impasse.

${ }^{1}$ É comum hoje a empresa credora entrar com o pedido de falência da empresa devedora só para forçá-la a pagar o que deve mais rapidamente. O credor não quer, realmente, a falência do devedor, só quer receber aquilo que lhe e devido. E o devedor acaba pagando, pois só o pagamento permite levantar o pedido de falência. 
Quanto à Justiça do Trabalho, o Instituto enfrentou quatro ações trabalhistas, tendo ganho uma delas. Tratava-se de funcionário demitido por justa causa que, inconformado, entrou na justiça, mas a decisão da empresa foi mantida. As outras três reclamações trabalhistas acabaram em acordo.

No campo tributário, o Instituto contesta a cobrança de ICMS sobre a importação de um aparelho de tomografia computadorizada, realizada em 1992. O valor do ICMS em discussão está avaliado em R\$36 mil. A empresa ganhou em primeira instância e aguarda decisão do tribunal. Ainda na área tributária, o Instituto tem outro processo em que discute a mudança de critério na cobrança de ISS. O ISS era cobrado anualmente com base no número de sócios, por ser a empresa uma sociedade de pessoas de profissão legalmente regulamentada. Mas a prefeitura mudou o critério e passou a cobrar o imposto sobre o faturamento. Como isso implicou em substancial aumento de tributação, a empresa contestou a mudança na justiça. Já ganhou em primeira e segunda instâncias. Aguarda agora decisão do Superior Tribunal de Justiça (STJ).

O Instituto não entrou com ação para reaver o compulsório sobre combustíveis, nem o PIS e o Finsocial pagos a mais (o STF decidiu que o compulsório e o Finsocial eram inconstitucionais e mudou a base de cálculo do PIS). A devolução a que teria direito não compensava os gastos com o processo judicial.

\section{Caso 2}

A CCC, empresa que importa e distribui no Brasil várias linhas de cosméticos norte-americanos, criada em 1992, nunca precisou recorrer ao judiciário. A empresa tem sete funcionários e dois sócios. "Faço qualquer coisa para não precisar ir à justiça. Negocio, faço acordo. Aliás, prefiro um mau acordo que resolva o problema. O judiciário é caro, lento e a incerteza quanto ao resultado é grande", declara o $\mathrm{Sr}$. MBG, um dos sócios da importadora.

$\mathrm{Na} \mathrm{CCC}$, a maior parte dos problemas envolve clientes que não pagam. Neste caso, a empresa negocia formas de pagamento da dívida. Se ainda assim o devedor não pagar, a empresa protesta o título de crédito e fica por isso mesmo. "Não vale a pena constituir advogado, pagar custas e cobrar judicialmente. Até porque isso não traz a certeza de receber o débito", afirma MBG. Às vezes, depois de algum tempo, o cliente devedor precisa limpar o nome para restabelecer seu crédito e procura a empresa para negociar a sustação do protesto.

O Sr. MBG conta que teve experiências pessoais muito ruins com o judiciário e que, enquanto for possível, vai evitá-lo. Ele tinha um terreno que foi objeto de tramoia do próprio cartório. O pessoal do cartório forjou, com assinaturas falsas, uma venda para terceiros. Esses compradores começaram a construir no terreno.

Entrei com uma ação judicial que durou mais de 10 anos. Enquanto isso, os compradores construíram a casa. No fim ganhei, mas não fiquei com o terreno. Teria de indenizar os gastos com a construção. Preferi vender para quem lá estava. Se fosse hoje, teria tentado um acordo. Não teria perdido tempo, dinheiro, nem me desgastado à toa.

\section{Caso 3}

A EL, escritório de contabilidade cujos clientes são, na maioria, micro e pequenas empresas, já recorreu ao judiciário "por absoluta necessidade". A empresa sucedeu à EL Processamento de Dados. A sucessão" provocou uma autuação fiscal, que acabou sendo discutida na justiça. A prefeitura cobrava indevidamente cerca de R $\$ 40$ mil a título de ISS. Os dois sócios da empresa eram também sócios da empresa antecessora que, além deles, tinha outro sócio. Este terceiro sócio saiu e a EL Processamento de Dados encerrou suas atividades. Os dois sócios remanescentes abriram a atual empresa, em outro endereço, mas no mesmo prédio.

Em 1990, um fiscal da prefeitura foi visitar a empresa desativada mas que ainda não tinha sido extinta junto aos órgãos competentes - e acabou no endereço da nova, confundindo uma com a outra. Foi esclarecido sobre a mudança na sociedade, informado sobre a criação da nova empresa. Todos os documentos foram postos à sua disposição, mas o fiscal não se convenceu e resolveu autuar a empresa desativada por sonegação do ISS.

Nas instâncias administrativas, os argumentos da empresa não tiveram sucesso e a autuação foi mantida. Em 1991, a EL resolveu entrar na justiça para pedir o cancelamento do auto de infração fiscal. Contratou um advogado, pagou perícia judicial e demais custas processuais. $\mathrm{O}$ valor gasto até agora com o processo está estimado em $\mathrm{R} \$ 5$ mil. A EL já ganhou em primeira instância, mas aguarda decisão do tribunal sobre o assunto. 
"Se ganharmos o processo em definitivo, teremos direito a reaver da prefeitura o que gastamos. Mas é outro processo complicado (tem de entrar no orçamento), demora muito tempo e, via de regra, não compensa", comenta um dos sócios da empresa.

Mas o prejuízo da EL não se restringe ao custo do processo judicial. Com a autuação, e enquanto não sair a decisão final, a empresa desativada não pode ser legalmente extinta. Isso significa que sua contabilidade tem de ser mantida e as suas obrigações fiscais cumpridas: pagar anualmente a Taxa de Licença de Funcionamento, declarar o Imposto de Renda, entregar a RAIS (Relação Anual de Informações Sociais) para o Ministério do Trabalho, entre outras.

No campo trabalhista, a EL nunca teve problemas. No comercial, quando acontece de algum cliente não pagar em dia os serviços prestados, a empresa negocia. Nunca foi além do protesto de título em cartório.

"Existe uma relação muito pessoal no relacionamento das pequenas empresas com seus clientes. Na grande maioria dos casos, a falta de pagamento se deve a dificuldades financeiras por que passam os clientes e isso é sabido. Então não adianta apertar mais ainda a situação e levar o cliente à insolvência total. É melhor aguardar que a situação melhore e o cliente salde os seus débitos. Postura muito diferente do relacionamento impessoal das grandes empresas, que não sabem nem quem está sendo cobrado", lembra um dos sócios.

\section{Caso 4}

A TSP, empresa fundada em 1987, que fabrica pranchas de surf, nunca teve qualquer tipo de experiência com o judiciário. Seus principais problemas concentram-se também na falta de pagamento dos clientes. Nunca enfrentou problemas com fornecedores, com funcionários ou com o Fisco. E sempre recorreu à negociação para manter o cliente. Em último caso, se a negociação não der certo, corta o cliente. Mas essa medida drástica só foi tomada três vezes. Normalmente, o acordo resolve. O Sr. MD, sócio da TSP, diz que não costuma protestar o devedor. "Quem quer dar o calote dá mesmo. Não é o protesto que vai fazer pagar. Nem seria uma ação judicial. Essas pessoas não se incomodam de ter o nome sujo. Mas esses são minoria. A maioria negocia e paga", avalia.
Para MD, tudo que passa pelo judiciário demora muito. E quando envolve dinheiro, segundo ele, não vale a pena, porque acaba inviabilizando outros negócios. "Mesmo que a TSP fosse envolvida em um processo judicial, eu procuraria resolver por acordo. Não ia levar o processo até ao fim", afirma. MD conta que deixou de comprar uma casa - que seria a sede da fábrica - porque o proprietário estava enredado em um processo judicial. "Era o único bem que ele tinha. Fiquei com medo de dar confusão mais para a frente e não comprei”, declara.

A TSP tem um advogado de confiança que contrata para elaborar contratos comerciais. Não é uma consultoria permanente. O advogado é pago por contrato feito.

$$
\text { Caso } 5
$$

A DAE, fundada em 1987 e que fabrica produtos de limpeza para armas de caça, precisou recorrer ao judiciário para defender-se de uma autuação da fiscalização do ICMS. O fiscal visitou a empresa e avaliou o valor do estoque em cinco vezes mais que a sua receita anual. Apesar de ter sido alertado do erro, o fiscal manteve aquele cálculo e a autuação. A solução foi entrar na justiça para contestar a autuação. A DAE ganhou o processo. Fora esse, não teve mais nenhum envolvimento com a justiça. Em caso de problema, negocia uma solução.

\section{Outros casos}

A IPR, empresa de informática criada em 1990, só foi ao judiciário para defender-se em um processo trabalhista. E a ação acabou resolvida por acordo. A empresa terceiriza vários serviços. E resolveu tomar essa iniciativa para economizar encargos sociais com funcionários. Privilegia a negociação em situações de conflito e tem funcionado bem assim. Vê o judiciário com reservas (a demora é o maior problema) e só recorreria a ele se não houvesse outra possibilidade.

Situação parecida é a do SCR, do ramo de restaurantes. Só teve experiência com a Justiça do Trabalho. Com fornecedores e clientes resolve eventuais problemas por acordo. 


\subsection{OBSERVAÇõES FINAIS}

As entrevistas realizadas indicam o tipo de visão e, consequentemente, o comportamento que as micro e pequenas empresas têm em relação ao judiciário. É um tipo de visão semelhante, guardadas as proporções, ao da maioria excluída da população. Esta maioria, quando tem acesso ao judiciário, é como réu ou vítima. Elas também não tomam a iniciativa de ir ao judiciário para encontrar soluções para os seus problemas. Vão quando não têm alternativa e precisam defender-se. Os motivos da população são os mesmos das micro e pequenas empresas: o judiciário é lento e muito caro.

Essa percepção do judiciário - caro, lento e inoperante - leva à sua negação como fonte de resolução de conflitos. Privilegia-se, então, a negociação ou outras formas de satisfação de necessidades.

O judiciário é tradicionalmente utilizado pela elite e alguns setores de classe média. Esse quadro não é diferente no universo das empresas. Ele é mais solicitado pela elite empresarial, ou seja, são as grandes empresas que mais recorrem a ele. As micro e pequenas empresas, que são a maioria das empresas em atividade, raramente o fazem. Mais do que isso, evitam-no, e só o procuram em último caso e numa atitude de defesa. Assim, o impacto econômico do funcionamento do judiciário sobre as atividades das micro e pequenas empresas é praticamente nenhum. O judiciário quase não é levado em conta enquanto instância de solução de litígios.

É curioso notar que o pequeno e microempresário tende a confundir a pessoa física com a jurídica. E a sua visão pessoal do judiciário, que é a mais comum e deriva de suas experiências pessoais, acaba se sobrepondo à empresarial, norteando as suas decisões.

A situação tem mudado um pouco para as pessoas físicas com os Juizados Especiais (antigos Juizados de Pequenas Causas). Lá, causas de menor complexidade e com valor de até 40 salários mínimos, são julgadas com menos burocracia. Não é preciso advogado para as causas de até 20 salários mínimos. Mas a grande procura e a falta de meios materiais, em São Paulo, têm retardado a solução dos litígios também nesses juizados. Em dezembro de 1997, alguns juizados estavam marcando audiências para abril do ano seguinte. Situação absurda para juizados que foram criados para julgar rapidamente.
Mas as pessoas jurídicas não podem litigar nos Juizados Especiais. “As micro e pequenas empresas deviam possuir uma instância de resolução de conflitos como os Juizados Especiais. Elas nem sempre podem pagar um advogado. E a maior parte de seus problemas poderia ser resolvida de forma satisfatória e rápida num Juizado Especial", conclui o Sr. PM, tributarista e consultor de empresas. 


\section{O IMPACTO DO JUDICIÁRIO NAS ATIVIDADES DAS INSTITUIÇÕES FINANCEIRAS}

Marcio Aith

\subsection{INTRODUÇÃO}

$\mathrm{E}$

ste capítulo tem como objetivo identificar, quantificar e detalhar o impacto das atividades do Poder Judiciário brasileiro nas operações de instituições financeiras instaladas no país. Foram entrevistados seis diretores de bancos, representando instituições com perfil e porte diferenciados. Todos os executivos ouvidos estão ligados às atividades do dia-a-dia dos bancos e, ao mesmo tempo, executam funções de direção. Decidem onde aplicar recursos e para quem emprestá-los (ou não emprestá-los).

Para a realização deste trabalho, procurou-se evitar entrevistas com pessoas ligadas diretamente aos departamentos jurídicos dos bancos, que pudessem ter avaliações viciadas sobre a importância do judiciário para as atividades do setor. A escolha das instituições procuradas e das pessoas entrevistadas exige outra explicação. $\mathrm{Na}$ verdade, o termo "instituição financeira" compreende não só bancos (de varejo, de investimento, etc.), mas também corretoras de valores mobiliários e distribuidoras de títulos. Trata-se de um universo amplo, compreendendo instituições com propósitos distintos e atividades diferenciadas. No Brasil, segundo alguns critérios, até os consórcios de automóveis são enquadrados como instituições financeiras, já que estão sujeitos à fiscalização, à intervenção e à liquidação pelo Banco Central. De comum, todas essas instituições têm a qualidade de lidar com a chamada poupança popular e/ou com investimentos de pessoas físicas e jurídicas.

Dada a amplitude desse universo, optou-se por concentrar as entrevistas e pesquisa num grupo de bancos. Tal escolha deveu-se ao fato de que, das instituições financeiras, são os bancos os que mais lidam com a poupança popular e cujo objetivo - o lucro - depende essencialmente do funcionamento da justiça, como veremos a seguir. Foi também relevante para a escolha o fato de que os bancos são basicamente as instituições que concedem crédito e que, portanto, correm riscos.
Como também veremos adiante, o aspecto da atividade de intermediação financeira que mais sofre a influência negativa das deficiências do Poder Judiciário é justamente o risco das operações de crédito. E os efeitos dessas influências são devastadores. Pelas respostas dadas pelos entrevistados, o mau funcionamento do judiciário limita a expansão das atividades no setor e, mais importante, aumenta consideravelmente os spreads bancários - em até 30\%, dependendo da situação.

Os diretores entrevistados representam seis bancos, incluindo instituições nacionais e estrangeiras, todas privadas. Dos seis, apenas três autorizaram a divulgação de seus nomes. Os demais alegaram, depois da entrevista, receio de que a publicação de suas avaliações causasse problemas junto à diretoria dos bancos e, principalmente, uma eventual retaliação dos juízes em processos já existentes ou futuros envolvendo suas instituições. O diretor de um dos bancos sugeriu que se fizesse uma solicitação formal de entrevista à diretoria do banco. Se o pedido fosse autorizado, ele permitiria a divulgação de seu nome. A resposta do banco foi negativa: a instituição, segundo a assessoria da direção, não participa desse tipo de pesquisa. O conteúdo da entrevista, no entanto, consta deste trabalho.

Apesar de ser negativa para os propósitos do trabalho (já que os diretores que não quiseram aparecer também não puderam pedir dados aos departamentos jurídicos de seus bancos), a não divulgação de seus nomes permitiu que os mesmos fizessem críticas abertas e aparentemente inéditas (partindo de banqueiros) ao Poder Judiciário, principalmente em relação à suposta imparcialidade do judiciário.

\subsection{INDICAÇÕES QUANTITATIVAS}

O estudo das respostas dadas pelos entrevistados revela um cipoal de situações nas quais os bancos se defrontam com as deficiências do Poder Judiciário. Além da conhecida e antiga morosidade da justiça brasileira, que transforma uma ação de cobrança ou de execução numa novela de até oito anos (um dos bancos tem processos de dez anos), os chamados bancos de varejo - principalmente os grandes - passaram a enfrentar, desde 1988, problemas dentro do judiciário que os levaram a não realizar ou reduzir negócios em determinados estados e a não realizar investimentos que, de outra forma, teriam levado adiante. 
Como resultado do impacto desses problemas nas atividades dos bancos, percebe-se um aumento dos juros cobrados nos empréstimos, talvez o impacto mais nocivo do mau funcionamento do judiciário, não só para os bancos (que usam esse aumento como defesa), mas para a economia. Percebe-se que esse aumento faz parte de um círculo vicioso assim resumido: para compensar e diluir as perdas financeiras causadas pela morosidade da justiça (dificuldade de cobrar, por meio de processos judiciais demorados, empréstimos não pagos), os bancos aumentam os juros; aumentando os juros, elevam a inadimplência e dependem cada vez mais da justiça morosa.

Entre alguns casos que revelam problemas mais recentes no judiciário, podemos citar as milionárias e suspeitas condenações judiciais impostas aos bancos no Estado do Maranhão e as dificuldades que algumas instituições financeiras tiveram para acompanhar e fiscalizar os processos de concordata do Grupo Santos e da Mesbla, e a falência da Cevekol - processos que, juntos, causaram aos bancos perdas de cerca de $\mathrm{R} \$ 1,5$ bilhão. Os bancos citaram ainda as decisões de juízes no Rio Grande do Sul, que insistem em limitar em $12 \%$ as taxas de juros previstas em contratos de empréstimos feitos pelos bancos, mesmo tendo o Supremo Tribunal Federal estabelecido que tal limitação - criada pela atual Constituição - depende de regulamentação.

De uma forma geral, verificou-se praticamente um consenso entre os bancos com relação ao impacto das deficiências do judiciário sobre suas atividades. Todos os diretores ouvidos consideraram que essas deficiências prejudicam gravemente o funcionamento da economia brasileira. Com relação às instituições para as quais trabalham, quatro dos seis afirmaram que essas deficiências prejudicam gravemente as atividades; os outros dois afirmaram que elas atrapalham, mas pouco.

O Sr. OS, diretor de um dos bancos, fez uma avaliação interessante sobre o efeito do mau funcionamento da justiça nos spreads bancários. Segundo ele, esse efeito é duplo, como se vê por esse trecho da entrevista:

O cálculo do spread leva em consideração, basicamente, os custos administrativos do banco e os riscos da operação. Como o judiciário tem uma estrutura burocrática grande, os bancos são obrigados a construir estruturas grandes o suficiente para acompanhar os processos existentes, o que encarece os custos administrativos do banco. De outro lado, a morosidade do judiciário torna mais arriscado aos bancos reaverem os créditos na justiça, o que também encarece os spreads.
O departamento jurídico do banco emprega diretamente 70 pessoas e, indiretamente, outras 78. Dos empregados diretos, 22 são advogados. O restante trabalha no setor de renegociação e contábil. Os empregados indiretos são 78 advogados credenciados pelo banco, que fazem serviços externos e eventuais. Toda essa estrutura custa ao banco, por mês, $\mathrm{R}$ \$1,1 milhão.

O Sr. OS calculou que o efeito dos custos administrativos do banco (inflados indiretamente pelo mau funcionamento do judiciário) e da morosidade do judiciário aumentam em $8 \%$ a $10 \%$ os spreads aplicados pelo banco nos contratos. Os diretores de outros três grandes bancos consultados calcularam o aumento do spread entre $10 \%$ e $30 \%$, variando conforme os índices de inadimplência.

$\mathrm{O}$ banco $\mathrm{N}$ é um banco de capital privado nacional (no momento em que este capítulo estava sendo escrito, o banco estava sendo vendido para uma instituição estrangeira) que emprega 5 mil funcionários e tem um ativo estimado em R\$ 6 bilhões. O banco tem um perfil popular. Em 1995, o banco $\mathrm{N}$ foi parte em duas mil ações na justiça, sendo que $75 \%$ dessas ações foram de natureza comercial e $25 \%$ trabalhista. Mil e quinhentas $(75 \%)$ das duas mil ações envolvendo o banco acabaram sendo resolvidas por meio de acordos, dentro ou fora do judiciário.

O impacto das despesas administrativas dos bancos (vinculadas ao judiciário) no cálculo do spread bancário pode ser melhor compreendido no caso do banco B, instituição de capital estrangeiro instalada no país. Segundo o Sr. AZ, vice-presidente do banco, uma pesquisa feita junto à matriz do banco, nos Estados Unidos, comprovou que, lá, contrata-se, para as mesmas funções administrativo-jurídicas, apenas $20 \%$ das pessoas arregimentadas no Brasil.

No caso do banco B, esse dado é quase que preponderante no cálculo do spread bancário aplicado pela instituição. Isso porque o banco é uma instituição financeira de elite que, ao menos por enquanto, não tem problemas com a recuperação de créditos na justiça. Em 1995, o banco foi parte em 205 ações, sendo 155 trabalhistas, 45 comerciais, 3 tributárias e outras duas na justiça comum.

As respostas do Sr. AZ sugerem que, ao contrário de quase todos os bancos similares, a principal preocupação do banco B com relação ao judiciário se concentra na justiça trabalhista. Isso porque, além do alto número de ações trabalhistas envolvendo o banco, se comparadas com as ações de 
outra natureza, $\mathrm{AZ}$ afirmou que a expectativa de ineficiência do judiciário, em seu setor de atividade, chega a causar a terceirização de atividades que requerem muita mão de obra. No entanto, de forma contraditória, o executivo disse que o banco nunca suspendeu a contratação de trabalhadores sob a alegação de que a Justiça do Trabalho é parcial em favor dos empregados.

As entrevistas feitas para este trabalho revelaram ainda uma outra sorte de problemas do judiciário que impactam as atividades dos bancos, como a corrupção e a politização das decisões. Podemos chamar esses problemas de heterodoxos, por duas razões. Primeiro, porque estão fora do dilema "morosidade/aumento do spread elevação da inadimplência" já explicado. Segundo, porque independem de uma reforma institucional do judiciário. Não guardam relação direta, por exemplo, com a implementação do efeito vinculante ou com a redução do número de recursos processuais.

As entrevistas feitas com diretores de três grandes bancos nacionais revelaram uma indisposição surpreendente e crescente dessas instituições com o Poder Judiciário com relação a esses dois problemas. Como exemplo, os três diretores entrevistados afirmaram que acontecimentos no judiciário estão levando esses bancos a pensarem seriamente em se retirar do Maranhão, estado onde as condenações por danos morais impostas aos bancos por juízes e por um Tribunal já passaram a cifra de $\mathrm{R} \$ 1$ bilhão. Segundo eles, que deram entrevistas separadamente, o caso do Maranhão é um indício de que há corrupção no judiciário brasileiro e que essa corrupção prejudica, e não beneficia os bancos.

O caso do Maranhão se resume a condenações milionárias ganhas por correntistas que se sentiram lesados por devoluções equivocadas de cheques e por protestos de títulos que já haviam sido pagos. Alguns desses correntistas são delegados de polícia e juízes. O caso é tão preocupante para os bancos que a FEBRABAN (Federação Brasileira das Associações de Bancos), a discreta e influente entidade que representa os bancos brasileiros, encomendou uma perícia de US\$ 100 mil que comprovou que uma mesma máquina de escrever fora usada para redigir as petições dos advogados dos correntistas, os laudos judiciais e as sentenças nos processos movidos contra os bancos. Justificando as condenações milionárias, um dos juízes que ganhou pessoalmente indenizações contra os bancos chegou a afirmar para a imprensa que "os bancos têm que pagar bastante porque eles têm muito".
Com relação à politização do judiciário, os três comentaram ainda que existe uma predisposição dos juízes em defenderem os devedores nas ações de cobrança movidas por bancos. Segundo eles, essa predisposição se confunde com democracia em estados como Rio Grande do Sul, onde juízes têm insistido em limitar em $12 \%$ os juros aplicados por bancos mesmo depois de o Supremo Tribunal Federal ter derrubado essa limitação. Os três fizeram ainda avaliações semelhantes sobre o que consideram o "caos" nos processos de concordata e de falência tramitando hoje no judiciário. Segundo eles, as instituições financeiras são obrigadas a aceitar qualquer acordo proposto por seus devedores para evitar processos de falência nos quais não há garantia de que os bens não serão desviados nem os funcionários da justiça comprados.

\subsection{INDICAÇÕES QUALITATIVAS}

As entrevistas revelam aspectos importantes do impacto do mau funcionamento do judiciário nas atividades das instituições financeiras. No entanto, é necessário interpretá-las de forma crítica e jogar luz sobre outros aspectos do relacionamento dos bancos com o judiciário não mencionados pelos diretores das instituições.

Se observarmos as respostas dos diretores dos bancos em relação a um eventual aumento do volume de seus negócios numa hipotética e instantânea melhoria do judiciário, verificaremos respostas positivas - todos afirmaram que o volume de negócios aumentaria. No entanto, é importante notar que esse aumento se daria na forma de um maior número de pessoas ou empresas com as quais os bancos fariam negócios, e não no volume de investimentos.

$\mathrm{O}$ diretor do banco $\mathrm{N}$, por exemplo, afirmou que se o judiciário brasileiro fosse reformado, tornando-se equivalente à justiça de países de Primeiro Mundo, o banco N aumentaria seu volume de negócios entre $20 \%$ e $40 \%$. Mas, ainda segundo ele, o volume de investimentos se manteria estável. Já o vice-presidente do banco $\mathrm{B}$ acredita que uma melhoria do judiciário permitiria um aumento no volume anual de investimento do banco em 5\%, um percentual que não chega a ser significativo.

Esses dois dados permitem concluir que, nos moldes atuais, os problemas do judiciário impedem que o crédito financeiro atinja uma determinada camada da população - incapaz de fornecer garantias e de 
pagar spreads altíssimos -, mas não restringem de forma expressiva os investimentos dos bancos, canalizados para setores da economia saudáveis, a seus olhos confiáveis e que não carecem de empréstimos. Para escapar do mau funcionamento da justiça, os bancos também procuram diversificar seus investimentos, ingressando em projetos que não guardam relação com a concessão de empréstimos (consórcios para telefonia celular, por exemplo).

É preciso notar também que o impacto negativo do judiciário nas atividades dos bancos não é novo. Justamente por essa razão, os bancos patrocinaram, nos últimos 25 anos, formas de reduzir esses efeitos. A mais notória dessas criações foi feita em 1969, durante o regime militar, e levada a cabo pelo governo da época. Trata-se da alienação fiduciária em garantia, um instituto jurídico atípico que permite aos bancos fazerem "justiça com as próprias mãos", nas palavras do diretor de um dos bancos ouvidos para o trabalho.

A alienação fiduciária, como é chamada, permite até hoje a venda extrajudicial do bem (automóveis e máquinas) dado em garantia pelo tomador de empréstimos bancários e a prisão imediata desse tomador caso a garantia desapareça durante o andamento do contrato de crédito. Em suma: ao tomar empréstimo de um banco, o devedor indica como garantia desse empréstimo um bem. Se o empréstimo não for pago, o banco poderá vender esse bem sem precisar ativar o judiciário. Caso o bem tenha desaparecido, o banco pode pedir a prisão sumária desse tomador, considerado por uma lei de 1969 como sendo um "depositário infiel".

Apesar de seu conteúdo jurídico complexo, a alienação fiduciária tem significado e objetivo simples: reduz fortemente o risco do emprestador do dinheiro, que ganha um instrumento rápido, extrajudicial, para a satisfação de seu crédito. O banqueiro (ou outra instituição financeira credora) possui a garantia física de um bem que cobre o valor da dívida e, ao mesmo tempo, a segurança de que o devedor irá para a cadeia, sem burocracias, se sumir com o bem.

Já na década de 90, à luz da aplicação do Código do Consumidor, as instituições financeiras conseguiram implementar como cláusulas nos contratos de empréstimo outro instrumento criado para que os bancos fugissem do judiciário e buscassem seus créditos não pagos por vias rápidas e sumárias. Esse novo instrumento ficou conhecido como "cláusulamandato". Limitava-se a um ou dois parágrafos nos contratos de empréstimos. Por meio dela, os tomadores davam poderes aos bancos, sob a forma de procuração, para que vendessem seus bens (dos devedores), pegassem recursos em nome deles ou simplesmente entrassem em suas contas correntes para quitar empréstimos não pagos. Depois de uma batalha jurídica de cerca de quatro anos, a cláusula-mandato foi anulada pela justiça, que obrigou os bancos a buscarem nos tribunais (e não por meios considerados agressivos e leoninos) a satisfação de seus direitos.

A alienação fiduciária e a cláusula-mandato revelaram agilidade e criatividade dos bancos para driblar um dilema crucial para eles, sintetizado na seguinte pergunta, feita por pelo menos três entrevistados: "Como posso emprestar dinheiro se não há meios rápidos de recuperá-lo em caso de inadimplência?" O que se viu neste trabalho é que, apesar dessa espantosa "agilidade contratual" revelada pelos bancos nos últimos dois anos, foi e é quase impossível para eles neutralizar completamente os efeitos das ineficiências do judiciário.

É preciso que se diga que o setor financeiro está, no momento, em profunda modificação. Com o fím da inflação, bancos até então tradicionais quebraram ou se fundiram. Bancos estrangeiros estão entrando ou montando projetos para ingressar no país, num aparente clima de competição. Nesse processo, o papel do judiciário tem ainda maior importância.

O banco U, ainda não definitivamente instalado no país, aumentaria seu volume anual de investimentos no Brasil em mais de $60 \%$, caso o judiciário fosse reformado. A instituição avalia no momento a possibilidade de entrar de vez no mercado brasileiro. Por enquanto, o banco possui um escritório em São Paulo que assessora empresas na emissão de eurobônus. Segundo o Sr. RL, diretor e gerente do banco U, as deficiências do judiciário prejudicam gravemente o funcionamento da economia brasileira e, também gravemente, o funcionamento do seu banco. O diretor explicou que a instituição para a qual trabalha é cuidadosa em sua decisão de investimentos. RL afirmou que, dada a situação atual da justiça brasileira, instituições como a sua preferem optar por negócios cujo andamento são tranquilos e independem de provocação do judiciário.

Ele relatou que alguns bancos, similares ao seu, escolhem tão bem os clientes que nem redigem contrato prevendo o pagamento dos serviços. "Eles fazem apenas um protocolo de intenção para definir a emissão de títulos e não há nenhuma preocupação quanto ao não pagamento da 
comissão negociada”. Por enquanto, o banco U tem 21 funcionários e emitiu em eurobônus, no ano de 1997, R \$ 1,7 bilhão. O banco não é parte em ações na justiça. $O$ único litígio envolvendo o banco foi resolvido por sua diretoria fora do judiciário.

Outro aspecto importante do mau funcionamento do judiciário no atual processo de transformação do sistema financeiro nacional guarda relação com os bancos que estão saindo de cena e deixando à mostra uma coleção de crimes financeiros. Trata-se, mais especificamente, da incapacidade do judiciário de julgar irregularidades praticadas por bancos e de condenar banqueiros, seja no campo civil seja no criminal. Uma pesquisa conduzida pelo Ministério Público Federal em Brasília constatou que, dos cerca de 400 casos de irregularidades praticadas no sistema financeiro e comunicadas ao judiciário nos últimos quinze anos, apenas quatro acabaram em condenações, de primeira e de segunda instância. Nenhum deles transitou em julgado. A prática revela ser praticamente impossível condenar em última instância alguém que pratica irregularidades no sistema financeiro nacional.

Esse dado também faz parte do quadro de mau funcionamento do judiciário, embora - de forma compreensível - não tenha sido mencionado pelos entrevistados. Percebe-se aí que os problemas do judiciário também podem beneficiar os bancos, principalmente aqueles com práticas antigas e que, aos poucos, parecem estar saindo de cena.

Analistas do setor afirmam que, nos próximos cinco anos, os bancos brasileiros poderão entrar num clima de competição que os forçará a baixar seus custos e juros. Se isso acontecer, espera-se que os próprios bancos pressionem o judiciário por mudanças. É importante notar que há cerca de uma década os diretores jurídicos dos bancos vêm se reunindo, ao menos uma vez por mês, para discutirem a relação do judiciário com o sistema financeiro e as questões jurídicas que interessam aos bancos. Nessas reuniões, sigilosas, já se discutiu corrupção de juízes, morosidade da justiça e os projetos de reforma do judiciário.

Como conclusão, podemos afirmar que existe e é relevante o impacto do mau funcionamento do judiciário nas atividades do sistema financeiro. Esse impacto pode ser medido (eleva em $10 \%$ a $30 \%$ os spreads cobrados) e limita os negócios feitos por bancos no país, além de impedir, em alguns casos, a entrada de novos investimentos. Apesar disso, o mau funcionamento do judiciário não é o principal problema que afeta os custos, operações e planos de investimentos dos bancos. O principal problema apontado por cinco das pessoas entrevistadas foi a carga tributária elevada. Os bancos revelaram uma notável criatividade e um natural poder para driblarem os problemas do judiciário e reduzirem seus riscos. 


\section{CONCLUSÕES}

Armando Castelar Pinheiro

O objetivo da pesquisa apresentada neste volume foi avaliar como e em que extensão os problemas enfrentados pelo judiciário no Brasil afetam o desempenho econômico do país. Para tanto, desenvolvemos primeiro um instrumental conceitual que explica como o mau funcionamento da justiça impacta a economia. Em seguida, concebemos uma metodologia que utiliza nosso instrumental teórico para mensurar esse impacto e a aplicamos ao caso do Brasil.

O primeiro capítulo revisou a literatura e elaborou, no plano teórico, a moldura dentro da qual se relaciona o desempenho judicial e a eficiência econômica. Identificamos quatro campos de relacionamento: tecnologia, eficiência, investimento e qualidade da política econômica.

Um bom judiciário contribui para o desenvolvimento econômico ao proteger a propriedade intelectual, encorajando dessa maneira as atividades de $P \& D$ e facilitando a importação de tecnologia de ponta. Igualmente importante, reduz os custos de transação e, como consequência, estimula os agentes econômicos a empreenderem negócios mais dispersos e em maior quantidade. Isso, por sua vez, conduz à maior difusão de conhecimento sobre tecnologias de produção, gerência, finanças e marketing.

Um judiciário disfuncional aumenta o custo e o risco das transações econômicas, distorcendo os preços e a alocação de recursos. Em razão de contar apenas com precários mecanismos judiciais para garantir o cumprimento dos contratos, as firmas podem fazer as seguintes opções: não entrar em negócios contratualmente complexos, combinar fatores de produção, distribuir suas vendas entre os diferentes mercados de forma ineficiente ou, ainda, manter recursos ociosos. Ao lado disso, as firmas têm um incentivo a se integrarem verticalmente, desempenhando internamente atividades que poderiam ser processadas de forma mais eficiente por outras empresas. A eficiência econômica também é prejudicada pela necessidade de se alocar recursos escassos para administrar conflitos. Disputas judiciais longas e frequentes consomem o tempo dos juízes, dos advogados e das partes. Os agentes econômicos também despendem recursos para se manterem atualizados em relação à legislação usualmente mais complexa que procura substituir um judiciário eficiente.

Um bom sistema judicial é essencial para permitir investimentos específicos em capital físico e humano. Isso porque se espera que, no momento em que um investimento específico é feito, a outra parte na transação tente agir de maneira oportunista, buscando expropriar o investidor. Um judiciário imparcial e ágil é necessário para impedir esse tipo de conduta. Além disso, investimentos específicos estão geralmente presentes em contratos de longo prazo, os quais tendem a ser mais incompletos e a requerer um árbitro para interpretar como as partes devem se conduzir em situações não antecipadas no contrato.

A qualidade da política econômica também se beneficia de um judiciário eficiente. Governos dotados de amplo grau de autonomia para traçar suas políticas econômicas geralmente dispõem de grande liberdade para agirem de forma oportunista. Na medida em que os agentes privados sabem disso, eles evitam fazer investimentos específicos em ambientes em que o governo goza de muita autonomia no desenho e na aplicação de suas políticas.

Deixar esses investimentos a cargo das empresas estatais seria uma possível "solução" para este problema. Uma outra alternativa seria estabelecer limites legais estritos para controlar a liberdade de ação do governo, reduzindo a sua autonomia. Mas uma medida dessa natureza reduziria a habilidade do governo de administrar a economia em um ambiente em constante mudança. $\mathrm{O}$ resultado final, nos dois casos, seria um equilíbrio subótimo, caracterizado por baixos investimentos, ou por baixa eficiência econômica ou, ainda, por uma política econômica ineficiente. Um equilíbrio socialmente mais desejável seria produzido por um judiciário eficiente e independente que permitisse ao governo flexibilidade no manejo de suas políticas, ao mesmo tempo em que garantisse o investidor privado contra o comportamento oportunista do governo.

Uma outra conclusão de nossa análise teórica é que, embora haja diversos canais através dos quais o funcionamento dos sistemas judiciais afeta o crescimento, o tamanho desse impacto e a sua natureza irão depender de dois conjuntos de fatores. O primeiro refere-se aos tipos de problemas enfrentados: são os tribunais tendenciosos, imprevisíveis ou somente lentos, mas de resto justos e previsíveis? 
A parcialidade, pelo fato de afetar o sentido de justiça em si, e a imprevisibilidade, porque impacta o incentivo de se procurar por justiça, são provavelmente os piores problemas. A morosidade também tem consequências sérias, tanto por estimular os agentes a se comportarem de forma oportunista, iniciando processos que têm poucas chances de ganhar, como por ser injusta com a parte que teve seus direitos feridos.

$\mathrm{O}$ outro conjunto de fatores inclui a complexidade da economia, a disponibilidade e a qualidade dos mecanismos que permitem aos agentes substituir o judiciário ou atenuar os problemas causados por seu mau funcionamento, e a existência de outros problemas que, sobrepondo-se à eficiência do judiciário, são suficientes, por si só, para limitar o investimento e reduzir a eficiência, como por exemplo, um ambiente hiperinflacionário.

Avaliar qual o impacto efetivo das disfunções de um sistema judicial sobre o crescimento é uma questão cuja resposta depende de pesquisa empírica específica. A revisão da literatura disponível sobre esse tema levou-nos a três conclusões principais. Primeiro, quase todos resultados empíricos baseiam-se em regressões de cross-sections de países, que utilizam diferentes medidas indiretas da qualidade dos sistemas legal e judicial para aferir seu impacto sobre as taxas de investimento e de crescimento da produtividade. Segundo, a maioria dos estudos conclui que o mau funcionamento dos sistemas legal e judicial compromete seriamente a formação de capital e o crescimento econômico, com efeitos comparáveis ao de um baixo nível de escolaridade da força de trabalho. Terceiro, modelos de regressão com cross-sections de países, embora sejam ferramentas úteis para identificar fatos estilizados e obter ordens de magnitude capazes de indicar onde residem as explicações para diferenciais de crescimento, em geral sofrem de graves problemas econométricos. A despeito de muitos relatos sugestivos, encontramos escassa evidência empírica sobre a magnitude ou a significância do efeito do judiciário na economia fora dessas regressões de cross-sections de países.

A metodologia que utilizamos para mensurar o quanto o mau funcionamento da justiça prejudica o desempenho econômico focalizou o seu impacto sobre a atividade empresarial. Por essa razão, nossas duas pesquisas de campo focaram a visão dos empresários sobre esse tema e a maneira pela qual o judiciário afeta o processo de decisão gerencial. A primeira pesquisa perguntou aos empresários como eles avaliam o judiciário brasileiro e levantou um conjunto de informações inéditas sobre a atividade litigante das empresas.

Os resultados dessa pesquisa, apresentados e discutidos no segundo capítulo, indicam que a morosidade é o principal problema do judiciário no Brasil. Na média, uma ação que não seja resolvida por acordo leva 31 meses até uma decisão final na Justiça do Trabalho, 38 meses na Justiça Comum Estadual e 46 meses na Justiça Federal. A falta de imparcialidade e os altos custos, embora também relevantes, foram classificados como problemas menores.

A pesquisa mostrou ainda que, por vezes, a morosidade da justiça beneficia, em vez de prejudicar as empresas. Isso é frequente em disputas trabalhistas e, em menor grau, tributárias. As empresas entrevistadas revelaram ainda que o benefício líquido de recorrer ao judiciário é em geral positivo. Finalmente, as empresas em nossa amostra com experiência no mercado internacional indicaram que, apesar das criticas ao judiciário brasileiro, não o consideram pior do que o de outros países em desenvolvimento, nem muito pior do que o dos países industrializados.

Uma segunda pesquisa de campo explorou mais de perto os canais que ligam a justiça à economia, perguntando aos empresários sobre o impacto do mau funcionamento do judiciário sobre a economia, de forma geral, e sobre suas respectivas firmas, em particular. Os resultados sugerem que a melhora no desempenho do judiciário teria um importante impacto na economia. A partir de uma média simples das respostas dadas ao nosso questionário, obtivemos que uma melhora do judiciário que o situasse em "Padrões de Primeiro - Mundo" resultaria em um aumento de produção, do investimento e do emprego de, respectivamente, $18,5 \%, 13,7 \%$ e $12,3 \%$. Se tomarmos essas médias separadamente para cada setor e utilizarmos como pesos a participação de casa setor no PIB, no investimento e no emprego, iremos obter uma média ponderada de crescimento dessas três variáveis de 13,7\%, $10,4 \%$ e $9,4 \%$, respectivamente.

Um aumento do investimento levaria o PIB a crescer mais rapidamente. Utilizando um modelo simples de crescimento, nós estimamos que o PIB cresceria a taxas de $25 \%$ mais altas se a qualidade dos serviços prestados pelo judiciário evoluísse na direção de padrões de " PrimeiroMundo". Ou seja, o mau funcionamento do judiciário reduz a taxa de crescimento do PIB em cerca de um quinto. É claro que essa é apenas uma 
medida aproximada. Uma estimativa precisa iria exigir, entre outras coisas, uma amostra maior, que permitisse estimar com precisão o impacto setorial sobre o investimento e levasse em conta a relação capital - produto de cada setor. Não obstante, esses valores deixam claro que o impacto do mau funcionamento da justiça sobre o crescimento econômico é significativo.

O projeto contou ainda com três estudos de caso sobre atividades (comércio exterior e intermediação financeira) e segmentos empresariais (micro e pequenas empresas) específicos. No primeiro estudo, ouviu-se vinte executivos de grandes empresas exportadoras, sendo a principal conclusão a de que o judiciário é ainda mais ausente da vida dessas empresas em suas atividades comerciais no exterior do que dentro do país. São três as razões que contribuem para isso.

Primeiro, essas empresas recorrem a um conjunto de instrumentos cartas de crédito, seguro de responsabilidade civil, etc. - que as protegem de situações que poderiam exigir o recurso ao judiciário. Segundo, a renegociação do contrato ou mesmo a aceitação de perdas é usualmente preferida ao conflito com clientes no exterior, seja para evitar que a disputa se arraste no tempo, bloqueando outros negócios, seja para preservar a imagem da empresa em mercados extremamente competitivos. Terceiro, quando o conflito se mostra inevitável, em geral as partes preferem o recurso aos tribunais arbitrais, que são normalmente (mas nem sempre) mais rápidos e mais bem informados sobre as questões em disputa.

O judiciário é mais presente nas decisões de investimento no exterior. Mas isso ocorre no contexto da análise do risco do país, que também considera um amplo conjunto de outras variáveis. Na prática, a má qualidade do judiciário não parece ter inibido o investimento de empresas em outros países, sendo o caso mais recorrentemente citado o da China, onde na visão dos empresários consultados não há uma tradição de respeito à lei.

$\mathrm{O}$ segundo estudo de caso mostrou que as micro e pequenas empresas têm muito pouco contato com o judiciário. Esse contato raramente se dá por iniciativa das empresas e, em geral, só ocorre quando elas precisam defenderse em causas trabalhistas, que constituem a maioria dos casos, ou em autuações fiscais, uma vez vencida a fase de contestação administrativa. $\mathrm{O}$ contador é quem usualmente orienta as empresas nesses casos. Em disputas comerciais, geralmente envolvendo contas a receber, a negociação, o protesto de títulos ou o simples abandono da disputa (por exemplo, abrir mão da cobrança de dívida) são em geral alternativas preferidas a recorrer ao judiciário. A lentidão da justiça e o alto custo de contratação de um advogado são os principais problemas que afastam as empresas do judiciário.

O setor que se mostrou mais sensível ao funcionamento do judiciário foi o de intermediação financeira, objeto do terceiro estudo de caso. Uma evidência dessa sensibilidade são as reuniões mensais de diretores jurídicos dos bancos para discutir a relação do judiciário com o sistema financeiro, em claro contraste com a posição dominante em outros setores, nos quais o judiciário não está presente no dia a dia da gestão das empresas. Outra é a expectativa de que uma melhora no desempenho do sistema judicial leve a um significativo aumento do nível de atividade das instituições financeiras.

Os bancos reclamam da morosidade da justiça e se sentem vulneráveis às posições de alguns juízes, que consideram viesadas em favor dos devedores. A reação dos bancos tem se dado de duas formas. De um lado, eles têm procurado criar instrumentos que reduzam sua vulnerabilidade ao mau funcionamento da justiça, acelerando o resgate de garantias e facilitando a cobrança de dívidas. São exemplos a alienação fiduciária e a cláusula-mandato. De outro lado, elevam os spreads bancários de forma a compensar o aumento do risco e dos custos decorrentes das práticas judiciais. De acordo com os bancos consultados, esse aumento dos spreads gira em torno de 10 a 30\%.

Como sugerido pelas análises teóricas e empíricas apresentadas neste volume, há ampla evidência de que o bom funcionamento do sistema judicial promove o crescimento econômico. Apesar disso, em economias em transição e em desenvolvimento, a reforma do judiciário tem sido morosa e em muitos casos nem mesmo se iniciou. Em particular, ela tem se atrasado muito em relação a outras reformas, como a liberalização do comércio exterior, a privatização e, em alguns países, a reforma da previdência.

Reformar o judiciário pode parecer, à primeira vista, uma tarefa simples. Se os recursos disponíveis não são suficientes para que se processe com rapidez e segurança o grande número de casos que chegam à justiça a cada ano, a solução seria aumentar a disponibilidade de recursos ou reduzir o número de casos. No primeiro grupo, estão as propostas de se investir mais em tecnologia de informação (informática) e preencher os cargos 
vagos de juízes. ${ }^{1}$ Ou seja, fazer mais da mesma maneira. Obviamente, isso implicaria o aumento dos gastos com o judiciário, o que se chocaria com a necessidade de reduzir o déficit público e ao mesmo tempo elevar a oferta de serviços como saúde, educação e segurança pública. Além disso, os expressivos aumentos de gastos com o judiciário,entre 1988 e 1997, sugerem que somente essa medida não resolveria o problema. $^{2}$

No segundo grupo estão as propostas para se reduzir o número de casos que chegam ao judiciário, ou, pelo menos, para agilizar a sua análise. A nova lei de arbitragem é um importante passo nessa direção. A primeira pesquisa de campo deste estudo mostrou que $66,3 \%$ das empresas brasileiras de grande e médio porte não incluem cláusulas de arbitragem ou de mediação em nenhum de seus contratos, enquanto $22,9 \%$ o fazem raramente. Consequentemente, há um grande potencial para se explorar com o uso desses instrumentos, ainda que a arbitragem seja em alguns casos uma alternativa cara, aconselhada principalmente em disputas envolvendo grandes somas e temas técnicos complexos.

Uma outra opção é tornar automática parte do processo decisório, sendo a "súmula vinculante" a proposta mais conhecida nessa direção. Através desse mecanismo, os tribunais inferiores teriam de seguir a decisão dos tribunais superiores no momento de julgar casos similares. Estima-se que em torno de $60 \%$ de todos os casos que chegam ao judiciário têm o setor público como uma das partes e envolvem um número muito pequeno de controversas (por exemplo, quebra de contratos quando do lançamento dos planos heterodoxos de estabilização no período 1986/91). Em princípio, a "súmula vinculante" poderia agilizar a análise da grande maioria desses processos, tornando o judiciário mais previsível, desencorajando as partes a encaminharem certos casos para os tribunais para se beneficiarem de sua morosidade, e liberando os juízes para se concentrarem nos casos restantes. ${ }^{3}$ Através dessas alternativas seria possível fazer mais com os mesmos recursos.

\footnotetext{
${ }^{1}$ De acordo com o Banco Nacional de Dados do Poder Judiciário, nas Justiças Comum, Federal e do Trabalho de $1^{\circ}$ Grau havia ao final de 1998 um total de 3247 cargos vagos (incluindo juízes substitutos), contra um total de 11.706 juízes em atividade. Nas Justiças de $2^{\circ}$ Grau, as vagas não ocupadas somavam 82 , contra 1668 cargos providos.

${ }^{2}$ Ver Pinheiro (1998) para uma análise da evolução dos gastos com o judiciário no Brasil.

${ }^{3}$ No entanto, há estudiosos que questionam a eficácia desse instrumento.
}

Embora útil, a visão do judiciário como produtor de serviços ignora alguns aspectos complexos do problema, que, na prática, consistem em impedimentos importantes à sua reforma. Além de toda a complexidade técnica, envolvendo um amplo número de leis e códigos processuais, há outras questões não legais que não têm respostas óbvias. Por exemplo, num contexto de recursos escassos, deve um país tentar garantir o máximo de "justiça" em cada caso individual, mesmo sacrificando o acesso de uma larga proporção da população a essa mesma justiça? $\mathrm{O}$ direito irrestrito à defesa e ao recurso a instâncias superiores, sem qualquer dúvida, tem aspectos positivos, mas também torna a justiça mais cara, lenta e menos acessível a amplos segmentos da população. Deve-se então alterar os procedimentos judiciais para se agilizar e reduzir os custos dos julgamentos, facilitando-se o acesso de um maior número das pessoas ao judiciário?

A resposta de um economista, e dos empresários em geral, a essas questões seria "sim", feitas as ressalvas naturais. Mas a maioria dos juristas e demais operadores do direito provavelmente responderiam "não", também com as devidas ressalvas. Aqui é importante refletir sobre a observação de Stigler a respeito dos mundos diferentes em que habitam economistas e juristas. De uma forma um tanto quanto simplificada, pode-se dizer que aos economistas falam mais alto os grandes números e os incentivos perversos criados pelo mau funcionamento da justiça. Para os juristas prevalece a visão de que na escolha entre a certeza e a celeridade deve-se sempre optar pela primeira.

Ainda de forma bastante simplificada, pode-se apontar outros dois pontos de discordância entre "economistas" e "juristas" sobre a atuação do judiciário em questões econômicas. Primeiro, a latitude com que muitos juízes interpretam o fato de a mudança no ambiente econômico permitir o não cumprimento de contratos é certamente maior do que a do economista típico, que entende que uma das funções do contrato é exatamente estabelecer uma distribuição implícita de riscos, aceita pelas partes quando este é celebrado. Segundo, os economistas entendem que os objetivos sociais devem ser perseguidos através do binômio taxação - subsídios, com o mínimo de interferência na eficiência econômica, e não através da interpretação diferenciada de contratos, ao contrário de muitos juízes, que defendem o princípio de que o juiz, enquanto juiz, tem um papel social a cumprir. 
A complexidade da questão e a diversidade de perspectivas sobre ela são, portanto, obstáculos a uma reforma do judiciário que reduza os custos econômicos do seu mau funcionamento. Não causa surpresa, assim, a dificuldade de se obter propostas claras, abrangentes e bem definidas, seja sobre a direção em que essa reforma deveria caminhar, seja sobre como proceder para lá chegar. Para muitos, a reforma judicial é percebida como um salto no escuro. Atores avessos ao risco resistem a mudanças em favor da manutenção do status quo. Também é importante ressaltar que muitas das mudanças propostas são defendidas como receitas de bolo, sem atentar para as especificidades institucionais de cada país. Como apontado no primeiro capítulo, a literatura não oferece uma clara definição do que venha a ser um bom judiciário, misturando com frequência o problema da eficiência com questões relativas aos objetivos de justiça. Em última instância, o estabelecimento de um equilíbrio entre esses diferentes objetivos irá exigir uma solução mais política do que técnica.

Uma segunda razão para o escasso progresso até aqui alcançado reside no fato de a sociedade estar relativamente adaptada ao atual sistema, não dispondo de uma visão clara dos custos que ele impõe e, ao mesmo tempo, percebendo que as reformas necessárias demandarão tempo e muito esforço político. De maneira geral, o nível de descontentamento com essa situação é muito inferior ao que existe em relação à instabilidade macroeconômica. Há, consequentemente, uma tendência a adiar a reforma. Isto é o resultado de dois fatores. Primeiro, muitos dos custos são arcados pelos contribuintes de uma maneira geral, e não de forma privada. Estes custos se perdem no meio de outros gastos públicos muito mais elevados. Segundo, o grosso do ônus social do mau funcionamento do judiciário é oculto. Resulta muito mais de investimentos e negócios que não ocorrem, ou que são processados de uma forma ineficiente, do que de gastos com litígios. Ao lado disso, há mecanismos alternativos privados para assegurar o direito de propriedade e para a resolução de conflitos, que atenuam a importância de sistemas judiciais disfuncionais.

Algumas evidências nesse sentido ficaram evidentes em nossa segunda pesquisa de campo. Metade dos empresários entrevistados declarou que o mau funcionamento do judiciário prejudicava seriamente o desempenho da economia, enquanto somente $25 \%$ afirmaram que o mesmo ocorria em relação às suas respectivas empresas. Tais resultados refletem o fato de as empresas brasileiras se acharem organizadas de maneira a evitarem "a qualquer custo" o contato com o judiciário, mesmo quando isso implica perder oportunidades de negócio, produzir ineficientemente etc. O judiciário pouco afeta as empresas porque elas tende a evitá-lo sempre que possível, mas é precisamente porque as empresas agem dessa maneira que a economia é prejudicada.

A complexidade da reforma judicial deve-se também à necessidade da reforma de outras instituições a ela relacionadas. É necessário, por exemplo, reformar a polícia de maneira que as decisões judiciais sejam rápida e efetivamente implementadas, um desafio talvez ainda maior do que reformar o judiciário. Igualmente necessário e difícil é formar melhores advogados. Num exame para o preenchimento de 170 vagas de juiz no Rio de Janeiro, no segundo semestre de 1997, somente 30 dos mil candidatos inscritos foram aprovados. Ainda assim, vários analistas argumentam que a formação média dos novos juízes está declinando.

Uma dificuldade complementar consiste no fato de que, na maioria dos países, a reforma do judiciário significa a passagem de um sistema desenhado para satisfazer os produtores de justiça, para outro orientado para o benefício dos consumidores (Economist, 1996). O problema está no fato de que enquanto as perdas infringidas aos produtores são claras, imediatas e concentradas, os benefícios para os consumidores se acham espalhados pela população, não são evidentes e só serão inteiramente sentidos a longo prazo.

Há diversos grupos que podem perder com a reforma judicial. Primeiro, pessoas que ganham a vida vendendo facilidades e agilizando processos judiciais - em países onde a corrupção é comum, tais interesses se afiguram particularmente pronunciados. Outra parte afetada serão os fornecedores de substitutos. ${ }^{4}$ Em terceiro lugar, os advogados litigantes. Quarto, as firmas e os agentes privados que se beneficiam de sistemas judiciários disfuncionais, ou seja, firmas que se mostram capazes de adiar o pagamento de impostos e reduzir os encargos sobre as folhas de pagamento recorrendo aos tribunais; companhias de seguros que ganham com o atraso do pagamento a clientes; locatários capazes de pagar baixos aluguéis sem correrem o risco do despejo; invasores de propriedades no campo e na cidade; para não mencionar as pessoas envolvidas em atividades criminais e ilegais.

${ }^{4}$ Ryterman et al. (1996, p. 14), por exemplo, mencionam que, na Rússia, a ausência de um bom sistema judicial levou à disseminação da prática de escambo e ao "aumento do número de intermediários, cuja única razão de existir parece consistir no desempenho do papel de fiadores de complicadas transações sob a forma de escambo". 
A dificuldade de se avançar com a reforma do judiciário também se deve à incerteza sobre o ganho líquido que grupos importantes podem aferir desse processo. Não é sequer claro como alguns grupos serão afetados. No Brasil, por exemplo, as firmas têm uma posição por vezes ambígua em relação a custos e benefícios da lentidão da justiça (ver, por exemplo, os resultados do segundo capítulo). Ninguém sabe o efeito líquido desses impactos. Ao lado disso, como observado por Haussman (1996, p. 45):

$\mathrm{Na}$ medida em que a reforma é um processo de tentativa e erro, o surgimento de benefícios tangíveis para grupos cujo apoio político é decisivo pode não se dar de forma suficientemente rápida e transparente.

Um último aspecto que torna a reforma do judiciário algo tão complexo consiste na necessidade de coordená-la com outras reformas, que também disputam os escassos recursos políticos do executivo. Muitas delas dependem de um bom judiciário para serem bem sucedidas, como é o caso da privatização dos serviços públicos. Neste e em outros casos similares, a reforma judicial constitui uma etapa crítica para se atrair investimentos privados para a economia. A dimensão da agenda de reformas e as múltiplas interações entre elas trazem à tona a questão sobre qual a sequencia ideal das reformas. A literatura a esse respeito não é conclusiva. North (1992, p. 27), por exemplo, observa que:

Não há teoria referente à dinâmica da evolução das estruturas políticas capaz de orientar os tomadores de decisão em muitos dos atuais esforços de reestruturação que estão em andamento em economias em desenvolvimento e em países que foram socialistas no passado. Mas o dilema é bastante claro. Mudanças lentas e incrementais serão sabotadas pela criação de "direitos de corrupção" por parte da burocracia existente. Isso implica que alterações radicais nas políticas devem ser acompanhadas pela reestruturação radical da burocracia. Mas isso só será possível onde a ideologia existente juntamente com os constrangimentos informais correlatos ao campo ideológico sejam pelo menos parcialmente complementares à criação de direitos de propriedade mais eficientes. Economias desprovidas da herança de instituições informais e de percepções ideológicas capazes de ajustá-las às tensões da competição, aos mercados impessoais e a outras consequências institucionais que emergem dos imperativos tecnológicos da segunda revolução econômica, simplesmente não podem se ajustar de um dia para o outro.
Levy e Spiller (1994) defendem posição semelhante, ao afirmarem que em muitos países reformas judiciais e outras correlatas devem preceder a privatização dos serviços públicos. De acordo com os autores, é necessário que uma estrutura institucional adequada esteja previamente montada para que a privatização ocorra de forma bem sucedida em setores como o de telecomunicações, por exemplo.

Hay et al. (1996) defendem uma visão oposta. Argumentam que, especialmente em economias em transição, privatizações e outras reformas liberais são necessárias para a criação de partes interessadas na reforma judicial. Consequentemente, argumentam os autores, a reforma do sistema judicial - incluindo-se os tribunais, ministério público e a polícia - não deve representar o ponto de partida, já que provavelmente irá transcorrer num longo horizonte de tempo. A reforma deve inicialmente se orientar na direção de tornar os sistemas legais e judiciais mais competitivos, tentando adaptá-los às práticas empresariais. ${ }^{5}$

A engenharia política necessária para se viabilizar a reforma judicial dentro e fora do Congresso é, portanto, bastante complexa. Obviamente, isso não significa que o tema não seja importante ou urgente. Até que o judiciário seja capaz de melhorar sua eficiência, continuará servindo majoritariamente a uma camada pequena da população e a grandes empresas. A maioria da população continuará a evitá-lo, abrindo mão do seu direito à justiça ou recorrendo a outros meios para tentar obtê-la. O resultado será a expansão de tipos de "justiça" paralelos e violentos que começam a surgir em alguns lugares. Caso não ocorram mudanças, a própria legitimidade do judiciário irá sofrer, postergando a consolidação da democracia. 


\section{REFERÊNCIAS BIBLIOGRÁFICAS}

ALESINA, Alberto \& Roberto PEROTTI, "The Political Economy of Growth: A Critical Survey of the Recent Literature", The World Bank Economic Review, vol. 8, n. 3, setembro 1994.

"Income Distribution, Political Instability, and Investment", European Economic Review, vol. 40, n. 6, junho 1996.

AUERBACH, Alan J., Kevin HASSET \& Stephen D. OLINER, "Reassessing the Social Returns to Equipment Investment", mimeo, The University of Pennsylvania, 1993.

BARRO, Robert, J., "Economic Growth in a Cross-section of Countries," Quarterly Journal of Economics, maio 1991, vol. 106, n. .2, 407-43.

BARRO, Robert J. \& Jong-Wha LEE, "Losers and Winners in Economic Growth", Proceedings of the World Bank Annual Conference on Development Economics 1993, 1994.

BARRO, Robert J. \& SALA-I-MARTIN, Xavier, “Convergence”, Journal of Economy, vol. 100, n. 2, Abril 1992, 223-51.

Economic Growth, Boston, MA: McGrawHill, 1995.

BERNARD, Andrew B. \& Charles J. JONES, "Technology and Convergence", Economic Journal, vol. 106, n. 437, Julho 1996.

BERNSTEIN, Lisa, "Opting Out of the Legal System: Extralegal Contractual Relations in the Diamond Industry", Journal of Legal Studies, vol. XXI, 1992.

BESLEY, T, "Property Rights and Investment Incentives: Theory and Micro-Evidence from Ghana". Princeton: Princeton University, Research program in developing studies, Discussion Paper 170, 1993.

BLEANEY, Michael E, "Macroeconomic Stability, Investment and Growth in Developing Countries", Journal of Development Economics, vol. 48, n. 2, março 1996.

BORNER, Silvio, Aymo BRUNETTI \& Beatrice WEDER, "Institutional Obstacles to Latin American Growth", International Center for Economic Growth, Occasional Papers n. 24, 1992.
BRUNETTI, Aymo \& Beatrice WEDER, "Subjective Perceptions of Political Instability and Economic Growth", mimeo, 1995.

BRUNO, Michael, "Development Issues in a Changing World: New Lessons, Old Debates, Open Questions", Proceedings of the World Bank Annual Conference on Development Economics 1994, 1995.

CAMARGO, José M., "Labour Standards, Labour Justice and the Brazilian Labour Market", Rio de Janeiro, Pontifícia Universidade Católica, mimeo, 1996.

CASELLA, Alessandra, "On Market Integration and the Development of Institutions: The Case of International Commercial Arbitration", European Economic Review, vol. 40, n. 1, janeiro 1996.

CLAGUE, Christopher, "Relative Efficiency Self-Containment and Comparative Costs of Less Developed Countries", Economic Development and Cultural Change, Abril 1991, vol. 39, n. 3, 507-30.

CLAGUE, Christopher, Philip KEEFER, Stephen KNACK \& Mancur OLSON, 1995, "Contract Intensive Money: Contract Enforcement, Property Rights and Economic Performance”, IRIS Working Paper 151.

COASE, Ronald H., The Firm, the Market and the Law, Chicago, The University of Chicago Press, 1988.

COOTER, Robert D., "The Rule of State Law Versus the Rule-of-Law State: Economic Analysis of the Legal Foundation of Development", paper prepared for the World Bank's Annual Bank Conference on Development Economics, Washington D.C., abril 25-26, 1996.

COOTER, Robert D. \& Daniel RUBINFELD, "Economic Analysis of Legal Disputes and Their Resolution", Journal of Economic Literature, vol. XXVII, n. 3, Setembro 1989.

CUKIERMAN, Alex \&Steven B. WEBB, "Political Influence on the Central Bank: International Evidence", The World Bank Economic Review, vol. 9, n. 3, Setembro 1995.

DE LONG, J. Bradford \& Lawrence H. SUMMERS, "Equipment Investment and Economic Growth", Quarterly Journal of Economics, vol. 106, maio 1991. 
DIXIT, Avinash K., The Making of Economic Policy: A Transaction-Cost Politics Perspective, MIT Press, Cambridge, Massachusetts, 1996.

EASTERLY, William \& Sergio REBELO, "Fiscal Policy and Growth: An Empirical Investigation", Journal of Monetary Economics, vol. 32, dezembro 1993.

ECONOMIST, “The End of the Feast,” julho, 27, 1996.

FAERMAN, M., "Perto do Colapso", Revista Problemas Brasileiros, janeiro/fevereiro de 1998.

FEDER, Gershon, "On Exports and Economic Growth," Journal of Developing Economics, vol. 12, n. 1/2, fevereiro/abril 1983.

FRY, Maxwell J., "Models of Financially Repressed Developing Economies", World Development, vol. 10, 1982.

GOULD, David M. \& William C. GRUBEN, "The Role of Intellectual Property Rights in Economic Growth', Journal of Development Economics, vol. 48, n. 2, março 1996.

GRAY, Cheryl W, "Legal Process and Economic Development: A Case Study of Indonesia”, World Development, vol. 19, n. 7, julho 1991.

\& Associates, "Evolving Legal Framework for Private Sector Development in Central and Eastern Europe", World Bank Discussion Paper No. 209, The World Bank, Washington, D.C., julho 1993.

GROSSMAN, Gene M. \& Elhanan HELPMAN, Innovation and Growth in the Global Economy, MIT Press, Cambridge, Massachusetts, 1992.

GUNNING, Jan W. \& Michael A. KUZZER, "Applied General Equilibrium Models for Policy Analysis", Handbook of Development Economics, Vol. IIIA, J. Behrman \& T. N. Srinivasan (eds.), Elsevier Science B.V., 1995.

HANDLIN, Oscar \& Mary E. HANDLIN, Commonwealth: A Study of the Role of Government in the American Economy: Massachusetts 17741861 (revised edition). Cambridge, MA, Belknap Press of Harvard University Press, 1969.
HARRISON, Ann, "Openness and Growth: A Time-Series, Cross-Country Analysis for Developing Countries", Journal of Development Economics, vol. 48, n. 2, março 1996.

HARTZ, Louis, Economic Policy and democratic Thought: Pennsylvania 1776-1860, Cambridge, MA, Harvard University Press, 1969.

HAUSSMAN, Ricardo, "La Economia Política de la Reforma Judicial en América Latina", mimeo, 1996.

HAY, Jonathan, Andrei SHLEIFER \& Robert W. VISHNY, "Toward a Theory of Legal Reform,", European Economic Review, vol. 40, n. 3 5, abril 1996.

HELPMAN, Elhanan, "Innovation, Imitation, and Intellectual Property Rights," Econometrica, vol. 61, n. .6, novembro 1993.

HIBBS, Douglas, Mass Political Violence: A Cross-Sectional Analysis, New York, Willey and Sons, 1973.

HOLDEN, P. \& S. RAJAPATIRANA, "Unshackling the Private Sector: A Latin American Story”, World Bank, LATAD, mimeo, Setembro 1994

HOROWITZ, M, The Transformation of American Law, Cambridge, MA, Harvard University Press, 1977.

JARQUÍN, E. \& E CARRILLO (eds.), La Economia Política de la Reforma Judicial, Banco Interamericano de Desarrollo, Washington, D. C., 1997.

JONES, Leroy P, “Appropriate Regulatory Technology: The Interplay of Economic and Institutional Conditions", Proceedings of the World Bank Annual Conference on Development Economics 1993, 1994.

KLEIN, Benjamim \& Keith B. LEFFLER, "The Role of Market Forces in Assuring Contractual Performance," Journal of Political Economy, vol. 89 , n. 4, agosto 1981.

KNACK, Stephen \& Philip KEEFER, "Institutions and Economic Performance: Cross Country Tests Using Alternative Institutional Measures", Economics and Politics, vol. 7, n. 3, novembro 1995.

KORMENDI, Roger \& Phillip MEGUIRRE, "Macroeconomic Determinants of Growth: Cross-Country Evidence", Journal of Monetary Economics, vol. 16, n. 2, setembro 1985. 
LANJOUW, Jean O. \& Josh LERNER, "Preliminary Injunctive Relief Theory and Evidence from Patent Litigation," National Bureau of Economic Research, Working Paper 5689, Julho 1996.

LA PORTA, R., F. LOPEZ DE SILANES, A. SHLEIFER \& R. VISHNY, "Law and Finance", NBER working paper 5661, 1996.

"Legal determinants of external finance "NBER working paper 5879, 1997.

LEVINE, Ross \& David RENELT, "A Sensitivity Analysis of CrossCountry Growth Regressions", American Economic Review, vol. 82, n. 4, setembro 1992.

LEVY, Brian \& Pablo T. SPILLER, "Regulation, Institutions, and Commitment in Telecommunications: A Comparative Analysis of Five Country Studies", Proceedings of the World Bank Annual Conference on Development Economics 1993, 1994.

LIN, Justin Y. \& Jeffrey B. NUGENT, "Institutions and Economic Development", Handbook of Development Economics, vol. IIIA, J. Behrman \& T. N. Srinivasan (eds.), Elsevier Science B.V., 1995.

MAKLER, Alexandre B., "The Privatization of Electricity Distribution in Brazil: A Public Law Analysis", Law School, University of California, Berkeley, mimeo, abril 1996.

MANKIW, N. Gregory, ROMER, David 8E WEIL, David N., "A Contribution to the Empirics of Economic Growth", Quarterly Journal of Economics, vol. 107, n. 2, maio 1992, 407-37.

MANSFIELD, Edwin, "Intellectual Property Protection, Foreign Direct Investment, and Technology Transfer", International Finance Corporation, Discussion Paper 19, 1994.

"Intellectual Property Protection, Foreign Direct Investment, e Technology Transfer: Germany, Japan and the United States", International Finance Corporation, Discussion Paper 27, 1995.

MAURO, Paolo, "Corruption and Growth," Quarterly Journal of Economics, vol. 110, n. 3, agosto 1995.
MICHALOPOULOS, C. \& K. JAV, "Growth of Exports in the Developing World: A Neoclassical View', Agency for International Development, Discussion Paper 28, Washington, D.C., 1973.

NORTH, Douglass C., Structure and Change in Economic History. New York: W. W. Norton, 1981.

Institutions, Institutional Change, and Economic Performance. Cambridge, U.K., Cambridge University Press, 1990.

, "Institutions", Journal of Economic Perspectives, vol. 5, n. 1, winter 1991.

, "Transaction Costs, Institutions, and Economic Performance", International Center for Economic Growth, Occasional Papers n. 30, 1992.

\& Barry C. WEINGAST, "Constitutions and Commitment: The Evolution of Institutions Governing Public Choice in the SeventeenCentury England", Journal of Economic History, vol. 49, n. 4, dezembro 1989.

OLSON, Mancur, "Economic Nationalism and Economic Progress, the Harry Johnson Memorial Lecture," The World Economy, vol 10, n. 3, setembro 1987.

1996, "Distinguished Lecture on Economics in Government: Big Bills Left on the Sidewalk: Why Some Nations are Rich, and Others Poor", Journal of Economic Perspectives, vol. 10, n. 2, spring 1996.

PACK, Howard, "Endogenous Growth Theory: Intellectual Appeal and Empirical Shortcomings," Journal of Economic Perspectives, vol. 8, n. 1, winter 1994.

PERKINS, Dwight, "Completing China's Move to the Market", Journal of Economic Perspectives, vol. 8, n. 2, spring 1994.

PINHEIRO, Armando C., "A Reforma do Judiciário: Uma Análise Econômica". Trabalho apresentado no seminário "Sociedade e reforma do Estado", São Paulo, março 26-26, 1998. 
PLANE, P., "Productive Efficiency of Public Enterprises: A Macroeconomic Analysis Based on Cross-Section Estimation of a Neoclassical Production Function,” Applied Economics, vol. 24, 1992.

POLINSKY, A. Mitchell \& Daniel L. RUBINFELD, 1996, "Optimal Awards and Penalties When the Probability of Prevailing Varies Among Plaintiffs", Rand Journal of Economics, vol. 27, n. 2, summer 1996.

PRZEWORSKI, Adam, "Comment of 'The Impact of Constitutions on Economic Performance", Proceedings of the World Bank Annual Conference on Development Economics 1994, 1995.

PRZEWORSKI, Adam \& Fernando LIMONGI, "Political Regimes and Economic Growth", Journal of Economic Perspectives, vol. 7, n. 3, summer 1993.

RAMEY, Garey \& Vlarie A. RAMEY, "Cross-Country Evidence on the Link Between Volatility and Growth", American Economic Review, vol. 85, n. 5, dezembro 1995.

REBELO, Sergio, "Long Run Policy Analysis and Long Run Growth", Journal of Political Economy, October 1991, vol. 94, 1002-37.

ROMER, Paul M., "The Origins of Endogenous Growth", Journal of Economic Perspectives, vol. 8, n. 1, winter 1994.

ROWAT, Malcolm, Waleed MALIK \& Maria DAKOLIAS (eds.), Judicial Reform in Latin America and the Caribbean: Proceedings of a World Bank Conference, World Bank Technical Paper 260. Washington, D.C., The World Bank, 233 pages, 1995.

SALA-I-MARTIN, Xavier X, "The Classical Approach to Convergence Analysis," Economic Journal, vol. 106, n. 437, julho, 1996.

SCHMIDT-HEBBEL, Klaus, Luis SERVÉN \& Andrés SOLIMANO, "Saving and Investment: Paradigms, Puzzles, Policies", The World Bank Research Observer, vol. 11, n. 1, fevereiro 1996.

SCULLY, Gerald W, "The Institutional Framework and Economic Development", Journal of Political Economy, vol. 96, n. 3, 1988.

SHAPIRO, Helen \& Lance TAYLOR, "The State and Industrial Strategy", World Development, vol. 18, n. 6, junho 1990.
SHAVELL, Steven, "Alternative Dispute Resolution: An Economic Analysis", Journal of Legal Studies, vol. XXIV, 1995.

RYTERMAN, Randi, Kathryn HENDLEY, Barry ICKES \& Peter MURRELL, "The Reach of Law into the Enterprise in Transition", World Bank, maio - junho, 1996.

SHERWOOD, Robert M., Geoffrey SHEPHERD \& Celso Marcos de SOUZA, "Judicial Systems and Economic Performance", The Quarterly Review of Economics and Finance, vol. 34, summer 1994.

SHIHATA, Ibrahim E, "Legal Framework for Development: The World Bank's Role in Legal and Judicial Reform", in Rowat et al., 1995.

SRINIVASAN, T. N. \& John WHALLEY (eds.), General Equilibrium Trade Policy Modeling, Cambridge, Massachusetts, MIT Press, 1986.

STIGLER, George, J., "Law or Economics?", The Journal of Law and Economics, vol. 35, n,2, october 1992, 455-68.

SUMMERS, Lawrence H. \& VINOD Thomas, "Recent Lessons of development", The World Bank Research Observer, vol. 8, n. 2, julho 1993.

TAYLOR, Lance, Edmar L. BACFIA, Eliana A. CARDOSO \& Frank J. LYSY, Models of Growth and Distribution for BraziI, World Bank, Oxford University Press, 1980.

VAN DEN BERGH, Roger, "The Growth of Law and Economics in Europe", European Economic Review, vol.40, n. 3-5, 1996.

WILLIAMSON, Oliver E., The Economic Institutions of Capitalism, Free Press, 1985.

., "The Institutions and Governance of Economic Development and Reform", Proceedings of the World Bank Annual Conference on Development Economics 1994, 1995.

WILLIG, Robert D., "Public versus Regulated Private Enterprise", Proceedings of the World Bank Annual Conference on Development Economics 1993, World Bank, 1994.

WORLD BANK, "From Plan to Market”, World Development Report, 1996. 
WORLD BANK, "The State in a Changing World", World Development Report, 1997.

YODER, R., P. BORKHOLDER \& P FRIEDËN, "Privatization and Development: The Empirical Evidence," Journal of Developing Areas, vol. 25, abril 1991.

\section{APÊNDICE METODOLÓGICO}

\section{A.1. Derivando a utilidade de se recorrer à justiça}

\section{A.1.1. O Caso Geral}

Formalmente, seja $U_{N}$ a utilidade de não se litigar; $U_{c}$ a utilidade esperada de se recorrer ao judiciário; e $\mathrm{U}_{\mathrm{A}}$ a utilidade esperada de se adotar um mecanismo alternativo de resolução do litígio. A disputa não chegará aos tribunais caso $\mathrm{U}_{\mathrm{N}}>\max \left(\mathrm{U}_{\mathrm{c}}, \mathrm{U}_{\mathrm{A}}\right)$ para ambas as partes envolvidas. A adoção de um mecanismo alternativo de resolução de conflitos será preferível se $\mathrm{U}_{\mathrm{A}}>\max \left(\mathrm{U}_{\mathrm{c}}, \mathrm{U}_{\mathrm{N}}\right)$ também para ambas as partes. $\mathrm{O}$ resultado é indefinido se para uma parte $\mathrm{U}_{\mathrm{N}}>\max \left(\mathrm{U}_{\mathrm{c}}, \mathrm{U}_{\mathrm{A}}\right)$ e para a outra $\mathrm{U}_{\mathrm{A}}>\max$ $\left(\mathrm{U}_{\mathrm{c}}, \mathrm{U}_{\mathrm{N}}\right)$. Nos casos restantes, as disputas serão levadas para os tribunais. ${ }^{1} \mathrm{~A}$ utilidade de cada parte pode ser expressa como:

$\mathrm{U}=\mathrm{U}\left[\mathrm{g}, \sigma^{2}\right]$

onde,

$\mathrm{g}=\mathrm{E}($ ganho líquido $)=\mathrm{E}($ ganho $)-\mathrm{E}($ custo do litígio $)$,

$\mathrm{E}($ ganho $)=\mathrm{E}\left[\mathrm{G} 1 /(1+\mathrm{i})^{\mathrm{T}}\right]=\mathrm{p} . \mathrm{VE}\left[1 /(1+\mathrm{i})^{\mathrm{T}}\right]$,

$\mathrm{E}\left[1 /(1+1)^{\mathrm{T}}\right]=\sum_{\mathrm{t}-1} \infty \mathrm{p}_{\mathrm{t}} /(1+\mathrm{i})^{\mathrm{T}}, \mathrm{e}$

$\mathrm{E}$ (custo do litígio) $=\mathrm{E}\left[\mathrm{c}_{\mathrm{A}}+\mathrm{C} /(1+\mathrm{i})^{\mathrm{T}}\right]=\mathrm{C}_{\mathrm{A}}+\left[\mathrm{pc}_{\mathrm{G}}+(1-\mathrm{p}) \mathrm{C}_{\mathrm{L}}\right]\left[\sum_{\mathrm{t}-1} \infty \mathrm{p}_{\mathrm{t}} /(1+\mathrm{i})^{\mathrm{T}}\right]$.

$\mathrm{U}_{1}>0$ e $\mathrm{U}_{2}$ é negativo, igual a zero ou positivo, caso a pessoa seja neutra, avessa ou propensa ao risco.

Nessas expressões, G representa o ganho bruto, uma variável aleatória que pode assumir valores 0 ou $\mathrm{V}$, onde $\mathrm{V}$ significa $\mathrm{o}$ valor dos direitos de propriedade em disputa. ${ }^{2}$ A probabilidade de se vencer é p eT

${ }^{1}$ A análise a seguir pretende demonstrar como a qualidade do sistema judicial afeta a conduta dos agentes. Cooter e Rubinfeld (1989) conduzem análise semelhante buscando identificar como as regras processuais, a percepção dos agentes e a natureza da disputa afetam a conduta das partes nas diversas etapas de uma disputa.

2 "Os direitos de propriedade incluem o direito de se utilizar um ativo, de se permitir ou excluir essa utilização por outros, receber a renda gerada pelo ativo, vendê-lo ou dele dispor de outra maneira. Em economias de mercado, esses direitos estão definidos na lei, usualmente de forma bastante detalhada”. [Banco Mundial (1996, p. 49)] 
representa o número de períodos até que uma decisão seja alcançada. T é uma variável aleatória, com $\mathrm{p},(\mathrm{t}=1,2, \ldots)$ sendo a probabilidade que a causa seja resolvida em t. Assume-se que a natureza da decisão é independente de quanto tempo esta leva para ser alcançada.

Já que somente depois de $\mathrm{T}$ períodos o litigante saberá se ganhou $(\mathrm{G}=\mathrm{V})$ ou perdeu o caso $(\mathrm{G}=0)$, receberá um direito que tem um valor presente igual $\mathrm{V} /(1+\mathrm{i})^{\mathrm{T}}$, onde $\mathrm{i}$ é a taxa de juros. ${ }^{3} \mathrm{O}$ custo esperado do litígio irá depender, além disso, de $\mathrm{c}_{\mathrm{A}}$, o custo de acesso, isto é da utilização de mecanismos específicos de resolução de disputas, e de $c_{\mathrm{G}}$ e $\mathrm{c}_{1}$, que refletem outros custos no caso de veredictos favoráveis ou desfavoráveis, respectivamente. ${ }^{4}$ Além disso,

$\sigma^{2}=\operatorname{Var}($ ganho líquido $)=\operatorname{Var}($ ganho - custo do litígio $)=$

$\left.=\operatorname{Var}(\mathrm{G}-\mathrm{C}) \mathrm{E}\left[1 /(1+\mathrm{i})^{2 \mathrm{~T}}\right]+\operatorname{Var}\left[1 /(1+\mathrm{i})^{\mathrm{T}}\right] \mathrm{E}(\mathrm{G}-\mathrm{C})\right]^{2}=$

$=\mathrm{p}(1-\mathrm{p})\left[\mathrm{V}-\mathrm{c}_{\mathrm{G}}+\mathrm{c}_{\mathrm{L}}\right]^{2} \mathrm{E}\left[1 /(1+\mathrm{i})^{2 \mathrm{~T}}\right]+\operatorname{Var}\left[1 /(1+\mathrm{i})^{\mathrm{T}}\right]\left[\mathrm{p} \cdot\left(\mathrm{V}-\mathrm{c}_{\mathrm{G}}\right)-(1-\mathrm{p}) \mathrm{c}_{\mathrm{L}}\right]^{2}$.

As funções de utilidade acima apresentadas podem ser adaptadas às três opções anteriormente elencadas - o recurso ao judiciário, a utilização de mecanismos alternativos de resolução de disputas, ou não se litigar bastando para isso fixar-se corretamente o valor dos parâmetros. No entanto, é necessário ter em mente que os parâmetros apresentam significados diversos para cada uma das partes - por exemplo, a probabilidade de uma parte ganhar é a probabilidade da outra perder. Além disso, as partes podem ter avaliações diferentes dos valores dos parâmetros, muito embora essas discrepâncias devam ser pequenas em um bom sistema judicial. Vale a pena assinalar, ainda, que os sistemas judiciais não operam em um vácuo institucional. Ao contrário, o desempenho de um sistema

\footnotetext{
${ }^{3}$ É importante notar que i pode ser alternativamente interpretada como taxa de preferência intertemporal, a qual pode diferir de um agente para outro. Em todos os casos, o valor presente tenderá a diferir entre os agentes, já que a taxa de juros paga por firmas distintas pode também variar (empresas pequenas usualmente pagam taxas de juro mais elevadas). Isso pode ajudar a explicar porque firmas grandes tendem a entrar em litígios com mais frequência do que firmas pequenas. Taxas de juro variam no tempo também, de maneira que pode fazer menos sentido entrar na justiça em certos períodos do que em outros.

${ }^{4}$ Há diferentes maneiras de se repartirem os custos do litígio entre as partes. Em alguns países, cada parte paga seu custo; em outros, o lado perdedor arca com o total dos custos.
}

judicial de um país irá depender do conjunto de sua estrutura institucional, em particular do sistema legal. ${ }^{5}$

\section{A.1.2. Um modelo simplificado}

Uma versão mais simples do modelo irá facilitar o entendimento dos benefícios do bom funcionamento de um judiciário. Assuma-se, para efeito da análise, que $\mathrm{T}$ apresenta uma distribuição geométrica, com a probabilidade de uma decisão ser alcançada no primeiro período igual a $\theta$ $(\mathrm{T}-\mathrm{G}(\theta)),{ }^{6}$ então,

$\mathrm{g}=\theta\left[\mathrm{p} . \mathrm{V}-\mathrm{p} \mathrm{c}_{\mathrm{G}}-(1-\mathrm{p}) \mathrm{c}_{\mathrm{L}} /(\mathrm{i}+\theta)-\mathrm{c}_{\mathrm{A}}\right.$

$\sigma^{2}=\theta\left\{p(1-p)\left[V-{ }_{G}{ }_{G}+{ }_{L}^{c}\right]^{2}+i^{2}(1-\theta)\left[p \cdot\left(V-c_{G}\right)-(1-p) c_{L}\right]^{2} /(i+\theta)^{2}\right\} /\left[\theta+2 i+i^{2}\right]$

Além disso, assumindo (1) uma aproximação simples de primeira ordem da função de utilidade, da forma $U\left[\mathrm{~g}, \sigma^{2}\right]=\mathrm{g}-\sigma$; (2) supondo que $\mathrm{c}_{\mathrm{G}}=\mathrm{c}_{\mathrm{L}}=\mathrm{cV}$; e ainda que (3) $\mathrm{c}_{\mathrm{A}}$ seja muito pequeno $(=0)$, a função de utilidade se simplifica para:

$\mathrm{U}=\theta \mathrm{V}[\mathrm{p}-\mathrm{c}] /(\mathrm{i}+\theta)-\mathrm{aV}\left\{\left[\mathrm{p}(1-\mathrm{p})+\mathrm{i}^{2}(1-\theta)(\mathrm{p}-\mathrm{c})^{2} /(\mathrm{i}+\theta)^{2}\right]\left[\theta /\left(\theta+2 \mathrm{i}+\mathrm{i}^{2}\right)\right]\right\}^{1 / 2}$.

\section{A.2. Um modelo simples para ilustrar o impacto do mau- funcionamento do judiciário sobre os investimentos}

Um modelo simples irá ajudar no entendimento da importância desempenhada pelos sistemas judiciais ao estimularem o investimento nos casos em que a natureza específica dos ativos constitui fato importante. Suponha que, para cumprir um contrato, uma firma deva investir \$1 e como

\footnotetext{
${ }^{5}$ Levy e Spiller (1994, p. 221) identificam cinco diferentes componentes da estrutura institucional de um país: [1] "Suas instituições legislativas e executivas - os mecanismos formais de se designar legisladores e tomadores de decisão, de elaboração e implementação das leis, e de determinaçã̃o das relações entre essas duas instituições," [2] "Suas instituições judiciais - os mecanismos formais da escolha dos juízes, da formatação da estrutura interna do judiciário e da resolução imparcial das disputas entre partes privadas ou entre estas e o Estado;" 131 "Seus recursos administrativos," [4] "Costumes e outras normas informais amplamente aceitas que constrangem tacitamente a ação de indivíduos e instituições”; e [5] "O caráter dos interesses sociais em disputa no interior de uma sociedade e o equilíbrio entre esses interesses, incluindo- se aí o papel da ideologia".

${ }^{6}$ Uma limitação da distribuição geométrica consiste no fato de não ter memória. Ou seja, a probabilidade de uma causa julgada no período $\mathrm{k}+1$, dado que não foi julgada até $\mathrm{k}$, é de $\theta$, para todo k. Isso, no entanto, não irá afetar nossos resultados.
} 
resultado receba como retorno $\mathrm{r}$ dólares por período. Na ausência do risco de que a outra parte no contrato aja de maneira oportunista, o valor esperado do montante que a firma receberá em troca de seu investimento tem um valor presente de $\mathrm{r} / \mathrm{i}$, onde $\mathrm{i}$ representa a taxa de juros. Consequentemente, a firma entrará no contrato se $r>i$.

Suponha agora que, devido à especificidade dos ativos, há a probabilidade $\mathrm{p}$ da outra parte agir de forma oportunista. Assuma-se que, em razão da possibilidade de êxodo da firma ser limitada, a outra parte pode expropriar uma proporção a do retorno da firma. De outra forma, $(1-\alpha)$ pode ser visto como o valor de recuperação do investimento da firma. Nesse caso, o valor atual esperado do retorno da firma sobre o investimento é [(1 $\pi) \mathrm{r}+\pi(1-\alpha) \mathrm{r}] / \mathrm{i}$. A firma, nesse quadro, só irá se engajar no contrato se $\mathrm{r}$ $>\mathrm{i} /(1-\pi \alpha)$. Ou seja, a firma irá requerer uma maior taxa de retorno para se acomodar ao risco da expropriação. Este prêmio de risco será tanto mais elevado quanto maiores os valores de $\pi$ e $\alpha$.

Caso a firma venha a recorrer aos tribunais para obrigar o cumprimento do contrato, poderá evitar ou ao menos limitar a extensão da apropriação. Suponha-se, como na seção A.1, que as firmas têm uma probabilidade $\mathrm{p}$ de ganhar o caso, que uma decisão será tomada depois de T períodos, e que os custos do litígio assumam uma proporção c do direito em disputa. Nesse caso, o valor presente esperado do retorno do investimento da firma é:

$(\mathrm{r} / \mathrm{i})\{1-\pi \alpha-\mathrm{p}(1-\alpha) \pi+\pi[\mathrm{p}(\theta+\mathrm{i}(1-\alpha)(1-\theta))-\mathrm{c} \alpha \theta] /(\mathrm{i}+\theta)\}$.

A Tabela A.1 fornece o valor da taxa de retorno mínima que a firma aceitaria para diferentes valores dos parâmetros. Diante de um judiciário imparcial, previsível, rápido, de litígios baratos ( $\mathrm{p}$ e $\theta$ elevados e c baixo), e de baixas taxas de juros, a firma irá aceitar uma taxa de retorno (r) só ligeiramente superior à taxa de juros (i). Mesmo diante da pior situação apresentada na Tabela A.1 ( $\mathrm{p}=0,5 ; \theta=0,1 \mathrm{e}$ i $=20 \%)$, no entanto, o judiciário ainda assim contribui para reduzir a taxa de retorno mínima aceitável, em contraste com os casos onde não há recurso a uma terceira parte para a obrigação dos contratos. ${ }^{7}$

\footnotetext{
${ }^{7}$ Note-se que o modelo não considera o ônus associado à imprevisibilidade do judiciário, como aconteceu na seção A.1. Caso essa fosse introduzida no modelo, a taxa de retorno demandada pela firma seria mais alta.
}

Tabela A.1: Impacto do judiciário sobre prêmios sobre taxa de juros ( $r / i-1$, em percentual)

\begin{tabular}{|l|c|c|c|c|}
\hline \multirow{2}{*}{} & \multicolumn{4}{|c|}{$(\pi=0,5 ; \alpha=0,5 ; \mathrm{c}=0,05)$} \\
\cline { 2 - 5 } $\mathrm{P}$ & $\mathrm{I}=8 \%$ & $\mathrm{i}=20 \%$ & $\mathrm{i}=8 \%$ & $\mathrm{i}=20 \%$ \\
\cline { 2 - 5 } & 8 & 13 & 17 & 24 \\
0,9 & 13 & 17 & 20 & 26 \\
0,5 & 19 & 22 & 24 & 28 \\
\hline
\end{tabular}

\section{A.3. Um modelo de ilustração do impacto do mau funcionamento do judiciário sobre os preços}

Um modelo simples irá ajudar a entender o impacto exercido pelo mau funcionamento dos sistemas judiciais sobre o sistema de preços e, como consequência, sobre a eficiência econômica. Assuma-se que uma firma serve um mercado com dois tipos de clientes. Os clientes de tipo 1 cumprem inteiramente o contrato $\mathrm{e}$ fornecem um retorno de $\mathrm{r}$ para a firma pelos serviços prestados. Os clientes de tipo 2 sempre ab-rogam o contrato. Nesse caso, a firma tem de renegociar o contrato e é capaz de recuperar um retorno de $\mathrm{r}(1-\alpha)$, líquido dos custos de renegociação. A firma não sabe qual o tipo dos clientes, mas dispõe do conhecimento que uma proporção $\pi$ pertence ao tipo 2. ${ }^{8}$ Utilizando um modelo padrão de determinação do preço de ativos (Capital-asset-pricing model), temos que, nesse caso, a firma irá fixar seu preço do seu serviço de modo a obter uma taxa esperada de retorno dada por:

$\mathrm{E}\left(\right.$ retorno) $\mathrm{i}+\mathrm{a} \sigma_{\mathrm{r}}$,

onde,

i é a taxa de retorno isenta de risco,

$\mathrm{E}($ retorno $)=(1-\pi) \mathrm{r}+\pi(1-\mathrm{a}) \mathrm{r}=\mathrm{r}(1-\mathrm{a} \pi)$

$\sigma_{\mathrm{r}}^{2}=\mathrm{r}^{2} \alpha^{2} \pi(1-\pi)$

de onde se deduz que a firma irá operar com uma taxa de retorno igual a:

$\mathrm{r}=\mathrm{i} /[1-\mathrm{a} \pi(\mathrm{i}+\mathrm{a} \sqrt{(1-\pi) / \pi]}$

${ }^{8}$ Este modelo não se distingue do outro no qual uma proporção b dos clientes das firmas são
de tipo 2 e cada um deles tem uma probabilidade e de renegar o contrato original. Para tal, de tipo 2 e cada um deles tem uma probabilidade
basta substituir a por b.s nas expressões seguintes. 
Fica claro a partir da expressão acima que r/i será tão maior quanto mais elevados forem os valores de $\alpha, \pi$, e a. Enquanto a reflete a aversão ao risco, $\alpha$ e $\pi$ são características do mercado em que opera a firma, as quais são influenciadas pela qualidade do sistema judicial de duas maneiras relacionadas. Primeiro, note-se que, em lugar de renegociar o contrato, a firma pode tentar obrigar seu cumprimento recorrendo aos tribunais. A utilidade de assim agir é dada por U, como estabelecido acima. Desse maneira, o modelo pode ser especificado mais adequadamente substituindo-se $1-\alpha$ por max (U, 1 $-\alpha$ ) nas expressões acima. Obviamente, porque os clientes de tipo 2 sabem que a firma irá apelar para os tribunais, irão se oferecer para renegociar a um valor de $1-\alpha$ igual ou superior a U. Neste caso, $\alpha$ irá se situar no intervalo definido por 1- $\alpha \geq \mathrm{U}_{\mathrm{f}}$ e $\alpha \geq \mathrm{U}_{2}$, onde $\mathrm{U}_{\mathrm{f}}$ e $\mathrm{U}_{2}$ representam a utilidade de se litigar para a firma e para os clientes de tipo 2 , respectivamente, caso este não se trate de um conjunto vazio. Em segundo lugar, o valor de $\alpha$ e a possibilidade de serem penalizados pelos tribunais, além da cultura e das normas sociais, irão determinar o valor de $\pi$. No caso limite, um bom judiciário reduziria o valor de $\alpha$ a ponto de $\pi$ tornar-se razoavelmente pequeno.

A Tabela A.2 fornece o valor do prêmio sobre a taxa de retorno livre de risco demandada pela firma para diferentes valores dos parâmetros. Embora o prêmio seja baixo - inferior a $10 \%$ - para valores relativamente baixos de $\alpha \mathrm{e}$ $\pi$, os quais prevaleceriam no caso de um judiciário que funcionasse bem, ele aumentaria de forma significativa para valores altos desses parâmetros. ${ }^{9}$ Pelo fato de os mercados onde as firmas se situam serem de natureza distinta, o valor do premio também irá variar de um setor para outro. Isto ilustra o argumento de que a introdução de distorções no sistema de preços é um caminho pelo qual judiciários que funcionam mal podem reduzir a eficiência.

Tabela A.2: Prêmio de risco devido a clientes de tipo 2 ( $r / i-1$, em\%)

\begin{tabular}{|c|c|c|c|c|}
\hline & & $\pi=0,2$ & $\pi=0,5$ & $\pi=0,8$ \\
\hline \multirow{3}{*}{$a=0,3$} & $\alpha=0,2$ & 6,8 & 14,9 & 22,6 \\
\hline & $\alpha=0,5$ & 19,1 & 48,2 & 85,2 \\
\hline & $\alpha=0,8$ & 34,4 & 108,3 & 278,8 \\
\hline \multirow{3}{*}{$a=0,6$} & $\alpha=0,2$ & 9,7 & 19,1 & 26,3 \\
\hline & $\alpha=0,5$ & 28,2 & 66,7 & 108,3 \\
\hline & $\alpha=0,8$ & 54,3 & 177,8 & 495,2 \\
\hline
\end{tabular}

\footnotetext{
${ }^{9}$ Note que tais resultados sugerem que o prêmio é mais sensível ao valor de $\alpha$ do que de $\pi$.
}

\section{A.4. Um modelo para ilustrar a importância de mecanismo de proteção}

Uma extensão simples do modelo discutido acima ajuda a esclarecer o papel de mecanismos de triagem de parceiros de negócios. Suponhamos no modelo anterior que alguma instituição se especializa em vender informações sobre a reputação e a capacidade de endividamento de indivíduos. Em particular, esse bureau de informações se mostrará capaz de, mediante o pagamento de uma taxa $\mathrm{f}$, reduzir a probabilidade de a firma fazer negócio com clientes do tipo 2 de $\pi$ para $\rho(<<\pi)$. Nesse caso, o valor esperado e a variância do retorno da firma tornam-se:

$\mathrm{E}($ retorno $)=\mathrm{r}(1-\alpha \rho)-\mathrm{f}$,

$\sigma_{\mathrm{r}}^{2}=\mathrm{r}^{2} \alpha^{2} \rho(1-\rho)$

de onde se obtém que a firma irá operar com uma taxa de retorno igual a:

$\mathrm{r}=(\mathrm{i}+\mathrm{f}) /[1-\alpha \rho(1+\mathrm{a} \sqrt{ }(1-\rho) / \rho)]$

A Tabela A.3 fornece o valor do prêmio sobre a taxa de retorno livre de risco, assumindo que essa taxa (=i) seja de $10 \%$ e o valor pago pela firma para obter informação sobre os clientes (=f) seja equivalente a $0,5 \%$. Os resultados na tabela mostram que, recorrendo a métodos que reduzam o risco de estabelecer contratos com clientes do tipo 2, a firma é capaz de diminuir substancialmente os custos sociais da fraca capacidade de se obrigar o cumprimento dos contratos por uma terceira parte. Obviamente, essa redução será tão mais significativa quanto menores forem os custos e maior a eficiência (f e $\rho$ mais baixos) desses mecanismos.

Tabela A.3: Prêmio de risco devido a clientes de tipo 2 ( $r / i-1$,em percentual)

\begin{tabular}{|c|c|c|c|c|}
\hline \multicolumn{2}{|c|}{} & $\rho=0,02$ & $\rho=0,05$ & $\rho=0,1$ \\
\hline \multirow{3}{*}{$\mathrm{a}=0,3$} & $\alpha=0,2$ & 6,3 & 7,5 & 9,1 \\
& $\alpha=0,5$ & 8,4 & 11,4 & 16,0 \\
& $\alpha=0,8$ & 10,5 & 15,7 & 23,8 \\
\hline \multirow{3}{*}{$\mathrm{a}=0,6$} & $\alpha=0,2$ & 7,2 & 8,9 & 11,2 \\
& $\alpha=0,5$ & 10,8 & 15,4 & 22,1 \\
& $\alpha=0,8$ & 14,5 & 22,8 & 35,3 \\
\hline
\end{tabular}

Nota: assumindo $i=10 \%$ e f $=0,5 \%$. 